\title{
State-wide fish tissue contaminants survey and effects of feeding type, season and gender on fish tissue contamination levels
}

\author{
Kenneth L. Stewart \\ West Virginia University
}

Follow this and additional works at: https://researchrepository.wvu.edu/etd

\section{Recommended Citation}

Stewart, Kenneth L., "State-wide fish tissue contaminants survey and effects of feeding type, season and gender on fish tissue contamination levels" (2009). Graduate Theses, Dissertations, and Problem Reports. 4539.

https://researchrepository.wvu.edu/etd/4539

This Thesis is protected by copyright and/or related rights. It has been brought to you by the The Research Repository @ WVU with permission from the rights-holder(s). You are free to use this Thesis in any way that is permitted by the copyright and related rights legislation that applies to your use. For other uses you must obtain permission from the rights-holder(s) directly, unless additional rights are indicated by a Creative Commons license in the record and/ or on the work itself. This Thesis has been accepted for inclusion in WVU Graduate Theses, Dissertations, and Problem Reports collection by an authorized administrator of The Research Repository @ WVU. For more information, please contact researchrepository@mail.wvu.edu. 
State-wide Fish Tissue Contaminants Survey and Effects of Feeding Type, Season and Gender on Fish Tissue Contamination Levels

\author{
Kenneth L. Stewart \\ Thesis submitted to the \\ Davis College of Agriculture, Natural Resources, and Design \\ at West Virginia University \\ in partial fulfillment of the requirements \\ for the degree of \\ Master of Science \\ in \\ Wildlife and Fisheries Resources \\ Patricia M. Mazik Ph.D., Chairperson \\ Stuart A. Welsh, Ph.D. \\ Janice Smithson, M.S. \\ Division of Forestry and Natural Resources
}

Morgantown, West Virginia

2009

Keywords: contaminants, fish, gender, mercury, organchlorine, polychlorinated biphenyls $(\mathrm{PCBs})$, seasonal variation, tissue 


\section{ABSTRACT \\ State-wide Fish Tissue Contaminants Survey and Effects of Feeding Type, Season and Gender on Fish Tissue Contamination Levels}

\section{Kenneth L. Stewart}

Fish tissue fillets from benthic, predator, and mixed diet species were collected from 24 different watersheds in West Virginia. Composite samples were prepared from three to six fish fillets collected at each site, and concentrations of the chemical contaminants polychlorinated biphenyls (PCBs) and mercury were determined for each composite sample. Differences in contaminant concentrations among three major categories of feeding type (predator, benthic, and mixed diet) were examined. Differences due to species of fish and among watersheds were also examined. Predators had significantly higher mercury concentrations than benthic or mixed diet feeders and benthic feeding fish had significantly higher PCB concentrations than predator fish, with no significant differences of PCBs in mixed diet fish. Species-specific analysis showed that walleye contained the highest concentration of mercury and bluegill contained the highest concentration of PCBs. The Shenandoah watershed had the highest levels of PCBs and mercury and the lower New River watershed had the lowest concentrations of PCBs; channel catfish obtained from a NC hatchery and subsequently released into WV waters contained the lowest concentration of mercury. Channel catfish and carp were sampled during May, July, and November from the Monongahela River, Morgantown, WV, to determine if seasonal differences in concentrations of PCBs occurred within the fillet, liver and gonadal tissues. In addition, gender of each fish was identified and differences in concentrations of PCBs due to gender were examined. Fillets for channel catfish and livers in carp were the only tissue that showed significant differences. For channel catfish fillets, May contained the highest concentrations of PCBs and November had the lowest concentrations of PCBs; neither was different in the July collection. For carp livers, November contained the highest level of PCBs and May the lowest with no differences in the July sample. No gender differences were observed for any tissue or species. 


\section{ACKNOWLEDGEMENTS}

First, I want to thank my committee members Pat Mazik, Stuart Welsh and Janice Smithson. Pat, thanks for putting up with me for so long, and having the patience to see me through. Stuart and Janice, thank you for sitting on my committee and helping me through. Janice for all the help with the data and maps, and Stuart for helping me collect the fish necessary to complete the project.

Thanks to the United States Environmental Protection Agency for funding and Jeff Bigler for helping get the project started. Thanks to the interagency committee, West Virginia Department of Environmental Protection, West Virginia Bureau for Public Health, West Virginia Division of Natural Resources, USGS Cooperative Fish and Wildlife Research Unit and West Virginia University for all the help. Thanks to WVDNR for the fish collections.

Thanks to Eda Holeskova and Dr. George Marovich for all the stats help.

Thanks to my wife Dr. Amanda Stewart, for all her help and reassurance through my research and for all the help you provided working with me to complete this project, and for being my best friend. For my family, my dad, Rev. Bill Stewart (RIP) who was always there for me and pushed me to be the best I could be but at the same time encouraged me by telling me I could accomplish whatever I set my mind to. For my mom, Dortha Stewart, who has been an example of strength, love and constant support to me. To my Sister, who has always stood by me and helped me through all of life's trials, and who I know, will always be there for me. 
Table of Contents

Chapter One

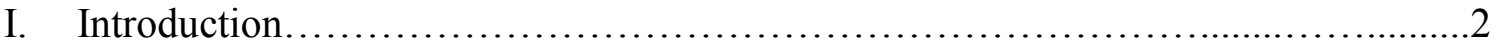

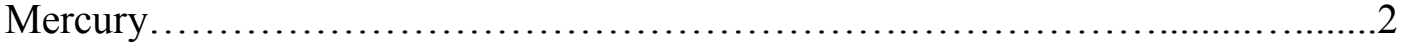

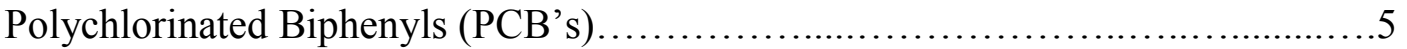

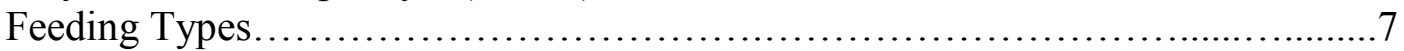

Benthic Feeding Fish . ..........................................................

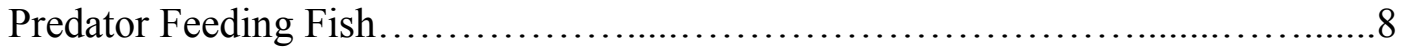

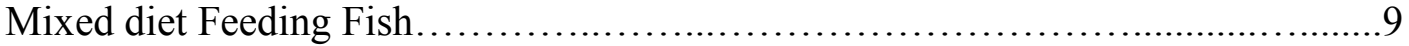

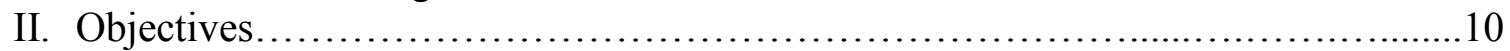

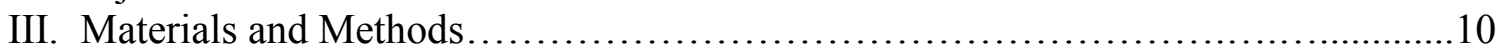

Sample Collection...................................................... 11

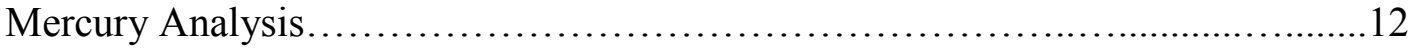

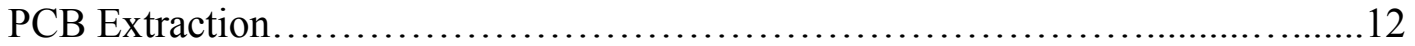

PCB Analysis........................................................... 14

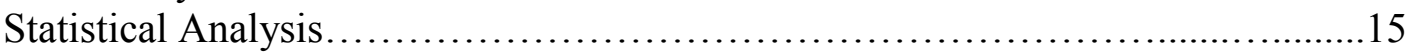

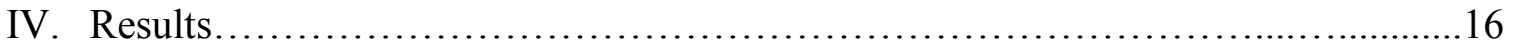

Comparison by Feeding Type and Species......................................... 16

Comparison by Watershed........................................................... 18

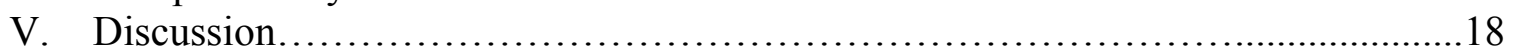

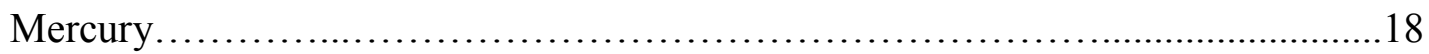

Species and Feeding Type..................................................... 18

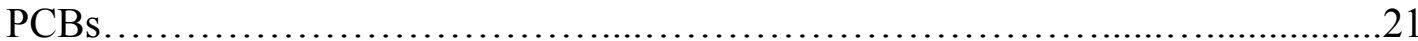

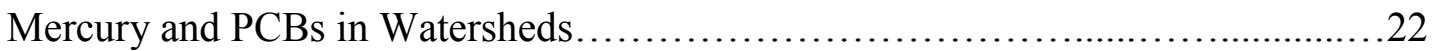

VI. Conclusions................................................................24

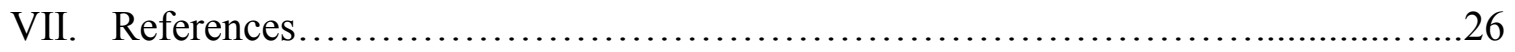

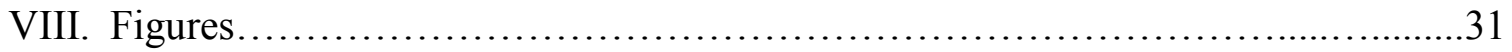

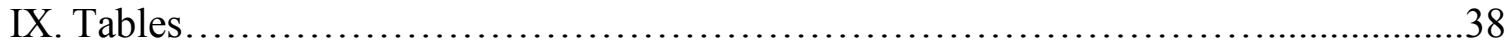

Chapter Two

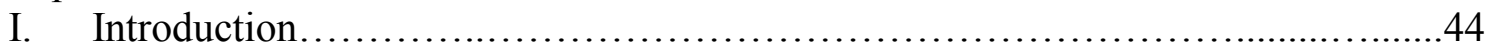

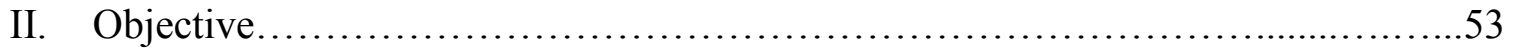

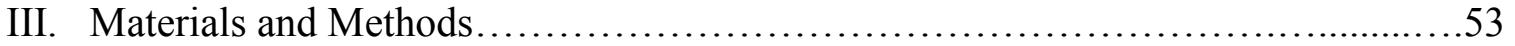

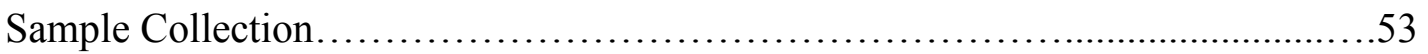

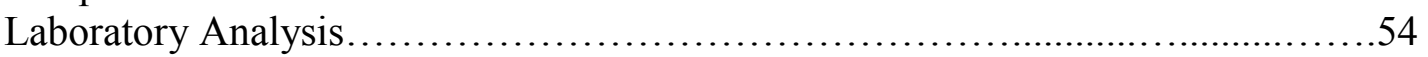

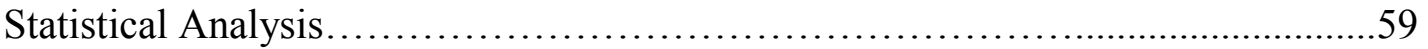

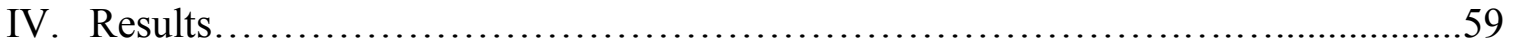

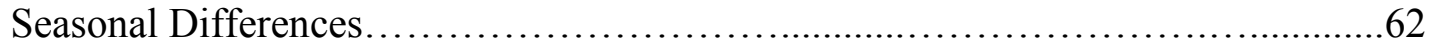

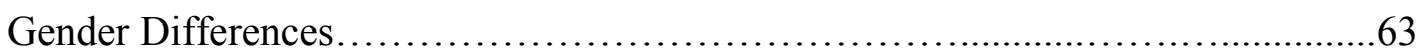

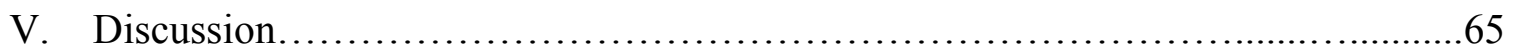

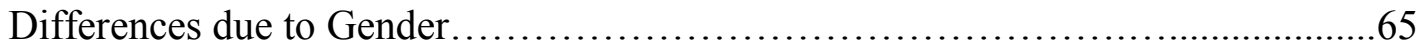

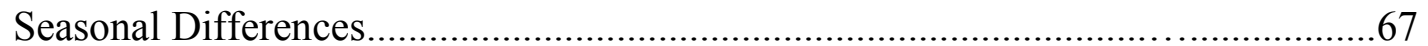

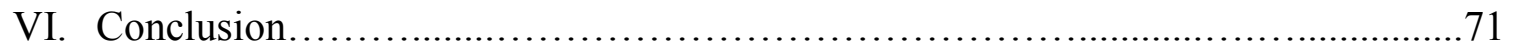

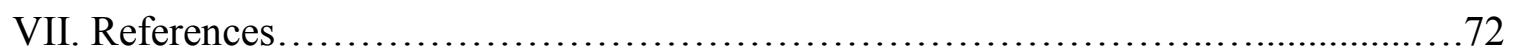

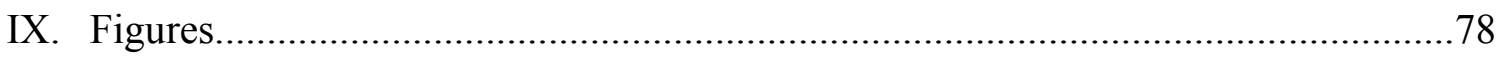

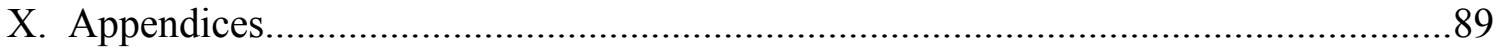




\section{Chapter 1}

Mercury and PCB Contamination of Fish Fillets in West Virginia 


\section{Introduction}

Contamination of the environment is of growing concern, as many contaminants can have a negative effect on human health. For example, the public may directly consume contaminants found in foods, such as fish. In fish tissue, lipophilic contaminants are of particular concern, as these compounds bio-accumulate in the fat stores of the animal. Likewise, ingestion of the contaminated fish tissue can result in bioaccumulation in humans, which may lead to serious health concerns not only in adults, but also in infants and children. An intra-agency committee comprised of the West Virginia Department of Environmental Protection (WVDEP), West Virginia Division of Natural Resources

(WVDNR), West Virginia Bureau for Public Health (WVBPH) and West Virginia University (WVU) developed a sampling plan to evaluate the current status of mercury $(\mathrm{Hg})$ and polychlorinated biphenyl (PCB) contamination of sport fishes in West Virginia. A preliminary study showed that contaminant concentrations in most of the streams within the state would trigger fish consumption advisories (Warnick 2002). Our project was developed as a larger-scale study of the entire state. The complete mercury and PCB analysis for the state of West Virginia was finished in the spring of 2004. As a result of the study, the intraagency committee released the 2005 consumption advisories for different sport fish in West Virginia.

\section{Mercury}

West Virginia and the Appalachian Region have a long history of coal mining and coal combustion for industry and power generation. West Virginia has 15 coal burning power plants that produced a combined 92.8 million megawatt hours and released an estimated 4,155.4 kilograms of mercury into the environment in 1998 (NRC 2000). Mercury 
is a naturally occurring element and is present in mineral deposits such as coal and soil and is released into the environment from natural sources including degassing from mineral deposits, degassing from aquatic systems and from volcanic emissions (Wang et al. 2004). Anthropogenic sources include coal fired power plants, combustion facilities and municipal solid wastes incinerators, hazardous waste incinerators and hospital incinerators and in the disposal of batteries, florescent bulbs, paints and other metals (Carpi 1997). Chlorine production is also a major contributor of mercury contamination in the environment. Chlorine production plants are considered limited contributors to world-wide mercury accumulation, but are considered to have a greater impact on localized air and water sources (Lindberg and Turner 1977). West Virginia has one of the few active chlorine production plants in the United States that is located in Natrium, WV.

Mercury is a toxic heavy metal present in the environment with no known biological function. Biological and chemical processes, including microorganism activity, transform mercury with low toxicity into forms with high toxicity. Specifically, inorganic mercury $\left(\mathrm{Hg}^{0}\right.$ and $\left.\mathrm{Hg}^{+2}\right)$ is converted to monomethylmercury $\left(\mathrm{CH}_{3} \mathrm{Hg}\right)$ and dimethylmercury $\left(\left(\mathrm{CH}_{3}\right)_{2} \mathrm{Hg}\right)$ (Clarkson 1993). Mercury in the environment is accumulated into living organisms, including insects, mammals and fish. Eighty to ninety five percent of total mercury found in fish tissue is in the form of methylmercury (MeHg) (Eisler 1987, Ward and Neumann 1999). Methylmercury, like many compounds, can be bioconcentrated through the food chain from the environment. Methylmercury is almost completely absorbed by fish when it is present in their food (Clarkson 1993). Jernelöv and Lann (1971) reported that fish consume mercury from food and can also absorb it through the gills, intestine and skin. Mercury is then distributed throughout the body by the circulatory system and concentrated 
in the liver, kidney and muscle. Mercury is accumulated in higher level (predator) fish from water, prey and aquatic fauna. Methylmercury levels in predator fish can average seven million times higher than the concentrations of methylmercury found in the surrounding waters (USEPA 1998, 1999). This is due to the accumulation of mercury within the body and the chemical form of mercury when it is absorbed, causing accumulation in the liver first, the kidney second and finally the muscle tissue. The kidney is the primary organ that determines if accumulation will continue or if the mercury will be excreted. Excretion of mercury is based on the equilibrium of mercury in the muscle and liver, when mercury accumulation is reduced, the concentration of mercury will decrease in the liver before the muscle due to the faster metabolism rate of the liver. Conversely, if accumulation increases, liver concentrations will be higher than muscle concentrations until the new equilibrium is reached, due to the excretion of mercury from the system by the kidney (Jernelöv and Lann 1971). Methylmercury is lipophilic, but also binds to protein and can be found in considerable amounts in fish muscle tissue.

Humans rapidly and almost completely absorb methylmercury (Clarkson 1993). Methylmercury is of great concern for pregnant women and women in their child-bearing years. Pregnant women consuming methylmercury in their diets bore children with nervous system damage at levels that produced only minor affects in the mothers. Chronic, low dose prenatal methylmercury exposure from mothers consuming fish has been linked to poor performance on neurobehavioral tests, particularly on tests of fine-motor function, language, visual-spatial abilities, and verbal memory (NRC 2000). Mercury has its greatest impact on the nervous system of the developing fetus; therefore, the pregnant woman and her developing child are the most sensitive human subpopulation. Children are also very 
sensitive due to their greater food consumption as a percentage of body weight and their decreased ability to eliminate mercury from their bodies (USEPA 1997, 1999).

\section{Polychlorinated Biphenyls (PCBs)}

Polychlorinated biphenyls are persistent toxic and carcinogenic environmental contaminants. They can bioaccumulate through the aquatic food chain into fish to levels from 2000 to over a million times greater than the ambient water (USEPA 1999). Polychlorinated biphenyls are a group of 209 isomers of synthetic halogenated hydrocarbons that were formulated in 1881. They were used for heat transfer agents, lubricant, dielectric agents, flame retardants, plasticizers, and waterproofing materials (Eisler 1986). Polychlorinated biphenyls were first synthesized in Germany, produced in Europe, and later produced in the United States. They were banned from production in the USA in the 1970's, however production in Europe and Russia continued until the 1990's (Giesy and Kurunthachalam 1998). Since 1971, PCBs have been used only for insulation or cooling in closed electrical components. The Toxic Substances Control Act of 1979 banned the manufacture processing, distribution, and use of PCBs except in totally enclosed systems because they are fat soluble, extremely persistent and will bioaccumulate in the environment. However, due to indiscriminate disposal and atmospheric transport, PCB residues are found worldwide.

Polychlorinated biphenyls are persistent in nature, slow to degrade, non-volatile, and have low water solubility (USEPA 1999, Pelletier et al. 2003). Polychlorinated biphenyl's are highly lipophilic, and accumulate in the fat of organisms. Accumulation of chemical compounds in organisms is referred to as bioaccumulation. Bioaccumulation of the contaminant results in biomagnification, which is an increase in the contaminant 
concentration in animals higher in the food chain (Kruse and Scarnecchia 2002, Pelletier et al. 2003). Biomagnification of contaminants in the food chain has been shown to cause a variety of diseases in many organs such as liver, brain, skin and also mortality in many fish species (Hammond 1972, Gore et al. 2002, Kruse and Scarnecchia 2002, Lundebye et al. 2004).

Various chemical properties affect the fate and storage of contaminants in aquatic organisms and higher level predators such as humans. One important chemical property of organic contaminants is referred to as the octanol-water partition coefficient $\left(\mathrm{K}_{\mathrm{ow}}\right)$ (Hawker and Connell 1988). The $\mathrm{K}_{\mathrm{ow}}$ affects the partitioning and bioaccumulation of a compound into organisms. Compounds with high $\mathrm{K}_{\mathrm{ow}}$ values and low solubility, such as PCBs, polynuclear aromatic hydrocarbons (PAHs), benzene and chlorinated compounds will accumulate faster and persist longer in organic tissues such as lipids. Conversely, low $\mathrm{K}_{\mathrm{ow}}$ compounds are not as readily concentrated into lipids and are lost or degraded faster than high $\mathrm{K}_{\mathrm{ow}}$ values (Miller and Wasik 1985). High $\mathrm{K}_{\mathrm{ow}}$ values (above 6 and 7) were found to be bioaccumulated mostly through the diet, while low $\mathrm{K}_{\mathrm{ow}}$ compounds (below 4) were found to be accumulated from the water (McKim and Heath 1983) whereas intermediate $\mathrm{K}_{\mathrm{ow}}$ values could be accumulated through both the water and the diet (Hellou et al. 1998).

Seventy five to ninety percent of PCBs entering an organism are absorbed through the gastrointestinal tract and stored in fatty tissue including the liver, skin, and in mother's milk (USEPA 1999). The PCBs are transferred through the placenta and through milk in mothers who consume contaminated fish (Swain 1988, Mendola et al. 1995). Acute doses have caused death in animals, although no human deaths have been documented due to PCB exposure. Chronic exposures in animal studies include hepatic, gastrointestinal, 
hematological, dermal, endocrine, immunological, reproductive, and developmental problems (ATSDR 1998). One human study demonstrated that PCB exposure resulted in lower birth weight, smaller head circumference, and shorter gestational age (Fein et al. 1994). Polychlorinated biphenyls are listed as a probable human carcinogen by the U.S. USEPA. They have also been shown to produce liver cancer in rats (ATSDR 1998).

\section{Feeding Types}

Fish species can be classified by feeding behaviors. According to Jobling (1996) there are four types of feeding behavior in fish. The first type is carnivorous fish which include piscivores (consume fish), benthophages (consume animals living in the sediment), zooplanktivores (consume planktonic animals), epifauna (consume prey from stones or rocks) and parasites. The second type is omnivores (mixed diet), which consume both plant and animal food. The third type is herbivores, which consume plants as food sources. The final type is detritivores, which eat detritus. For the purpose of this study, all fish were categorized into three different feeding categories, predator fish (piscivores), benthic feeding fish and all others (any fish that does not feed primarily on benthic or other fish, refered to as mixed diet). Although certain benthic fish will consume plants and animals such as benthophages, zooplanktivores and epifauna, they were placed in one of the three categories based on the most frequent type of feeding by that particular fish species.

\section{Benthic Feeders}

Benthic feeders have a diverse diet including decaying plants or aquatic organisms, insects or fish. For example, the benthic feeding channel catfish (Ictalurus punctatus) eats aquatic insects, crayfish, mollusks and crustaceans and will also feed on decaying plants or 
animals. Other benthic feeders such as carp (Cyprinus carpio) and white suckers (Catostomus commersoni) feed primarily on aquatic insects, snails and clams. Benthic species will tend to accumulate non-polar compounds quicker than polar compounds due to their diets.

The type of food consumed by benthic fish will affect bioaccumulation of contaminants in the fish tissues (Clements et al. 1994, Jackson 1996, Gobas et al. 1999). Benthic feeding fish species will accumulate non-polar contaminates in their lipid reserves. Contaminants such as organochlorine pesticides and PCBs are cyclic in shape and therefore do not have a polarity. These compounds are lipophilic in nature and will accumulate in the lipid or fat reserves of the organism such as the belly flap, lateral line, subcutaneous and dorsal fat, dark muscle, gills, eye, brain and internal organs (USEPA 1999). Non-polar organic contaminants have a high affinity for organic particles such as microorganisms and algae (Karickhoff et al. 1979, Voice and Webber 1983, Baker et al. 1985). Hellou et al. (2002) found that non-polar organic contaminants are in the greatest concentration in the fatty tissue and the internal organs (which also have high lipid deposits) and are in much lower concentrations in the blood and the muscle tissue (Hellou et al. 2002).

Accumulation of organic contaminants may occur more rapidly in fishes consuming crayfish than those consuming emergent aquatic insects and other invertebrates that are lower in the food chain. Crayfish are opportunistic feeders, feeding on other benthic invertebrates, aquatic insects, detritus and even dead organisms (Kay et al. 2005). Mussels, conversely, filter feed and therefore accumulate lipophilic contaminants from algae and suspended solids. These contaminants can be accumulated in the mussels from the aqueous phase if water 
column concentrations are high. They can also accumulate in the feces and pseudofeces of mussels and then accumulate in the amphipods who feed on feces (Bruner et al. 1994).

\section{Predatory Fish}

Predator fishes feed primarily on other fish, crayfish, and occasionally insects. Piscivorous species richness increases with water body size (Oberdorff et al. 1993). Lipophilic contaminants can bio-accumulate in the fat stores of animals feeding on benthic diets; conversely, piscivorous fish tend to accumulate polar contaminants in the muscle tissue more readily. Mercury is an example of a polar contaminant. Inorganic mercury is excreted from the body readily; therefore accumulation of inorganic mercury in fish tissue is minimal. Organic mercury (specifically methyl mercury) is not easily excreted and therefore accumulation of mercury within the predator's tissue can be significant (Jernelöv and Lann 1971).

Generally, predator fish have higher mercury accumulation than other feeding types. Mercury is accumulated by predators primarily through prey consumption $(\sim 60 \%)$. Piscivorous fish consuming smaller contaminated fish would likely bio-accumulate polar contaminants, causing larger predator fish to have higher polar contaminant levels (mercury) than smaller predator fish (Zhou and Wong 2000, Burger et al. 2001, Power et al. 2002). Due to persistence in the environment and poor elimination of mercury from fish, mercury accumulation is highest in the longest lived, top predatory fish (Clarkson 1993).

\section{Mixed Diet Fish}

Omnivore fish are defined as species that can survive on a wide range of food items (adult diet consisting of at least 25\% plant or detritus and at least $25 \%$ live animal matter) and are not impacted by changes in food structure within their environment (O'Reilly et al. 
2007). Although omnivores are defined as fishes that consume an even percentage of plant and animal matter, none of the fish collected for our study fit the definition of omnivore feeding species. Therefore, fish that do not fit the definition of omnivore and are also not top predators will be referred to as mixed diet feeders.

Mixed diet fish will contain contaminant concentrations that vary depending on where the fish is found. Fishes with mixed diets located in lakes will have different diets than those found in rivers or streams and therefore will accumulate contaminants differently depending on the ecosystem in which they are found. Kamman et al. (2005) found significant variation in mercury concentrations in different water body types such as lakes, reservoirs and rivers. They also found that mercury concentrations in mixed diet fish varied greatly among water body types but noted that mixed diet species should be considered, along with high level predators, as mercury accumulators due to the variation observed within this feeding type.

Fishes with mixed diets have lower concentrations of contaminants in their tissues compared to that of predators or benthic feeders. Scientists have suggested that due to the diversity of their diets, mixed diet feeding fish should have less mercury than comparable predator fish and less PCBs than comparable benthic feeding fish (Cabana et al. 1994, Hill and Napolitano 1997, Borga et al. 2001, Burger et al. 2001, Power et al. 2002).

\section{Objectives}

The objectives of this study were to determine contaminant levels of mercury and PCBs in different trophic levels and different feeding types (predator, mixed diet and benthic) of fish in the state of West Virginia.

\section{Materials and Methods}


Sample sites and species were determined by the interagency technical committee (Figure 1). Sample sites are representative of watersheds in WV and were selected based on three criteria: the potential for mercury and/or PCB advisories, the lack of previous contaminant data, and angling popularity.

\section{Sample collection}

The WVDNR collected a composite ( 3 to 6 fish per composite) of 3 size classes of benthic and pelagic fish from 56 sites in WV (Figure 1). A size class was defined as a group of fish of similar size where the smallest individual in a composite is no less than $75 \%$ of the total length of the largest individual. Fish were collected and transported to WVU as per standard USEPA protocol (Appendix I).

Upon arrival of samples at WVU, handling, processing and laboratory analysis of mercury and PCBs followed standard protocols approved by the USEPA (Appendix II). Research previously done at WVU has shown that composite samples can be used for analysis as compared to analyzing individual fillets (Warnick 2002).

Fish were processed for analysis at the National Research Center for Coal and Energy's Analytical Laboratory at West Virginia University. The fish were processed to collect the edible portion of the fish tissue (fillets). Fillets were removed according to standard methods (USEPA, 1995). All fillets were then stored at $-20^{\circ} \mathrm{C}$ in properly labeled aluminum foil until the tissue was homogenized. Tissues were homogenized according to standard methods (USEPA 1995). After each fillet was homogenized, samples were combined into composites by combining all the homogenized fillets into one sample, then the sample was cut into four subsamples, subsamples one and three were combined and mixed thoroughly and subsamples two and four were combined and mixed thoroughly, then the two 
mixes were combined and mixed thoroughly. This step was repeated two more times to ensure proper mixing of the homogenized samples. The mixed composites were then placed in glass sample jars (I-Chem 250ml jars, and Fisher Scientific, Pittsburgh, PA) and then identified with the appropriate sample label.

\section{Mercury Analysis}

Samples were analyzed for mercury using USEPA method number 245.6 "Determination of mercury in tissues by Cold Vapor Atomic Absorption Spectrometry" (Varian VGA-77, Walnut Grove, CA). A 0.2 gram sub-sample of tissue was weighed from the composited sample and placed in a clean digestion vial. Four $\mathrm{ml}$ of concentrated sulfuric acid and $1 \mathrm{ml}$ of concentrated nitric acid were added. The weighed samples were then placed in a hot block digester at $58^{\circ} \mathrm{C}$ until tissue was completely dissolved. The samples were then cooled by placing them in an ice bath, adding $15 \mathrm{ml}$ of potassium permanganate solution, 8 $\mathrm{ml}$ of potassium persulfate solution was added and the samples were stored in the dark overnight. To each sample, $6 \mathrm{ml}$ of sodium chloride-hydroxylamine solution were added. The samples were then aspirated into a spectrometer atomic absorption analyzer (Varian SpectraAA-640, Walnut Grove, CA) fitted with a vapor generation accessory (Varian VGA76, Walnut Grove, CA). The samples were aspirated with equal parts stannous chloride and hydrochloric acid and with an argon flow of $5 \mathrm{ml} / \mathrm{min}$. The instrument was calibrated from $0.5 \mathrm{ug} / \mathrm{l}$ to $20 \mathrm{ug} / \mathrm{l}$.

\section{PCB Extraction}

The frozen samples were each labeled and then extracted via USEPA method 3545, Accelerated Solvent Extraction (ASE) of Organic samples (USEPA 1992). Fish tissue samples were extracted with a Dionex ASE 200 (Dionex Corp., Sunnydale, Ca) using the 
Dionex application note (Number 337). Samples were extracted in $33 \mathrm{ml}$ stainless steel vials and collected in $60 \mathrm{ml} \mathrm{I-Chem} \mathrm{certified} \mathrm{jars.} \mathrm{Extraction} \mathrm{was} \mathrm{completed} \mathrm{by} \mathrm{weighing} \mathrm{a} \mathrm{clean,}$ dry solids porcelain dish, recording the weight, then weighing a 10 gram portion of sample and recording the weight. The sample was then dried overnight in a $104^{\circ} \mathrm{C}$ drying oven. Samples were then taken out of the drying oven and cooled to a constant volume by placing in a desiccator and repeatedly weighing until weight stabilizes. Dried weight of samples was then recorded and a percent dry matter was calculated on all samples. Samples were then combined with 10 grams of diatomaceous earth and mixed and crushed thoroughly using a mortar and pestle. Each stainless steel extraction vial was prepared by placing a cellulose extraction disk (D28 filter, Dionex Corp. Sunnydale, Ca) in the vial, placing 5 grams of activated alumina, placing another cellulose filter on top of the alumina. This step was added to remove the co-extracted lipid faction of the sample. The sample vial was then filled with the diatomaceous earth and dried sample mixture and capped. Samples were spiked with 0.5 ul of surrogate standard Decachlorobiphenyl (Restek, Bellefonte, PA) at a concentration of $0.1 \mathrm{mg} / 1$ for all standards. Recoveries of the surrogate were determined after the samples were analyzed on the Gas Chromatograph, Varian CP-3800 GC (Varian Analytical, Chicago III). The extraction procedure was conducted using the following program: system pressure $10 \mathrm{MPa}(1500 \mathrm{psi})$ with an oven temperature of $125^{\circ} \mathrm{C}$ and an oven heat up time of 6 minutes with 2 static cycles each 5 minutes, a flush volume of $60 \%$ of extraction cell volume with a nitrogen purge of $1 \mathrm{MPa}(150 \mathrm{psi})$ for 60 seconds for a total extraction volume of $40 \mathrm{ml}$ using hexane as the solvent. The extract was then concentrated to less than $1 \mathrm{ml}$ on a Zymark TurboVapII concentrator (Zymark, Hopkinton, MA) under an ultra pure nitrogen stream, with a pressure of $14 \mathrm{psi}$ and a water bath temperature of $40^{\circ} \mathrm{C}$. Sample extracts were then 
brought up to $1 \mathrm{ml}$ in the Zymark concentration tubes and quantitatively transferred to a 2.0 $\mathrm{ml}$ amber sample vial. Sample extracts are then cleaned using USEPA method 3665A, Sulfuric acid/Permanganate Cleanup (USEPA 3665). In this procedure, $1 \mathrm{ml}$ of sample extract was transferred to a $10 \mathrm{ml}$ glass vial (Pyrex ${ }^{\circledR}$ Tube with Teflon ${ }^{\circledR}$-fluorocarbon-resinfaced rubber lined caps, Fisher Scientific, Pittsburgh, PA) and $5 \mathrm{ml}$ of sulfuric acid diluted 1:1 with deionized water was added to the hexane extract. After the vial was allowed to sit and any exothermic reaction or gas evolution no longer occured, the sample was capped with a Teflon ${ }^{\circledR}$ lined screw cap and vortexed (with a noticeable vortex in vial) for 1 minute. The sample was then allowed to sit for one minute to allow the layers to separate (aqueous and Hexane solvent). If the hexane layer was found to be cloudy or highly colored, the sulfuric acid layer was removed and $5 \mathrm{ml}$ of 1:1 sulfuric acid was added to the sample and the procedure repeated until a clean, clear layer hexane layer was obtained. After obtaining a clean hexane layer, it was removed and quantitatively transferred into a new clean $10 \mathrm{ml}$ Pyrex ${ }^{\circledR}$ vial. An additional $1 \mathrm{ml}$ of hexane was added to the sulfuric acid portion and capped and shaken to ensure quantitative transfer of all PCBs from the sulfuric acid solution. This second hexane layer was removed and combined with the original hexane layer. To this combined hexane fraction, $5 \mathrm{ml}$ of aqueous potassium permanganate solution was added at 5 percent $\mathrm{w} / \mathrm{v}$ in DI water. Again the vial was capped and vortexed for 1 minute. The sample was then checked for color and cloudiness. The procedure was repeated until the hexane layer was clear. After the hexane was found to be clear, the hexane layer was quantitatively transferred to a clean $10 \mathrm{ml}$ Pyrex ${ }^{\circledR}$ tube and repeated with a potassium permanganate solution ( $25 \mathrm{~g}$ of potassium permanganate in $500 \mathrm{ml}$ of DI water). The clean hexane layer from the final process was then allowed to sit and separate into layers and the hexane layer 
was removed and then concentrated on the Zymark TurboVapII, as described above, to $1 \mathrm{ml}$ of sample. If concentration occurred less than $1 \mathrm{ml}$, additional hexane was added to bring sample volume to $1 \mathrm{ml}$ and the final $1 \mathrm{ml}$ of hexane sample was transferred to a $2 \mathrm{ml}$ amber colored sample vial.

\section{PCB Analysis}

Samples were analyzed for PCBs, using USEPA method 8082 (USEPA 1992). The Aroclor method of analysis was used by identifying the type and amount of each Aroclor based on patterns of Aroclor samples from Aroclor 1016, 1221, 1232, 1242, 1248, 1254 and 1260 standards injected at a $1 \mathrm{mg} / 1$ concentration. Tissue samples were analyzed on a Varian CP-3800 GC (Varian Analytical, Chicago, IL) equipped with a Varian 8410 auto injector with 10 position rack, dual 1177 split/split less injectors and dual $\mathrm{Ni}^{63}$ Electron Capture Detectors (ECD). Injectors were set at $250^{\circ} \mathrm{C}$ and a split ratio of 10:1. The ECD detectors were set at a temperature of $320^{\circ} \mathrm{C}$, with a range of 1 , a time constant of fast, a cell current of N2std. Column flow was controlled by Type 13 electronic flow controllers at a column flow of $5 \mathrm{ml} / \mathrm{min}$ through the columns and a makeup flow of $25 \mathrm{ml} / \mathrm{min}$ through the detectors. Carrier and makeup gas was ultra high purity nitrogen. The injectors were kept at a constant temperature of $250^{\circ} \mathrm{C}$ during the injection process. The column oven temperature program was an initial temperature of $150^{\circ} \mathrm{C}$, held for 0.5 minutes, then a ramp of $12^{\circ} \mathrm{C}$ to $190^{\circ} \mathrm{C}$ and held for 4 minutes, then a final ramp of $4^{\circ} \mathrm{C} / \mathrm{min}$ to a final temperature of $275^{\circ} \mathrm{C}$ and a hold of 10 minutes to make the total analysis time of 39.08 minutes. The instrument was calibrated according to USEPA method 8082. Data analysis was performed on the GC software Star Chromatography version 6.20 (Varian Inc., Walnut Grove, CA).

\section{Statistical Analysis}


State wide survey samples were analyzed for PCBs and mercury concentration in predator, benthic and mixed diet species for 22 watersheds and 29 species (SAS 1989). A mean comparison ANOVA was used to analyze the data with a $95 \%$ confidence interval. The significant level of $\mathrm{p}<0.05$ was used for all statistical analysis. Watershed and species data were analyzed using a non parametric KS analysis (Wilcoxon test) due to the outliers and non symmetric distribution of both mercury and PCB results.

\section{Results}

The WVDNR collected 295 composite samples ( 3 to 6 fish per composite) from 56 collection sites representing 22 watersheds (Figure 1). Twenty-nine species were collected and analyzed for mercury and PCBs. Mercury and PCB results are listed in Appendix III. The highest mercury level found in all composites was $900 \mu \mathrm{g} / \mathrm{kg}$ for largemouth bass (Micropterus salmoides) composite collected from Elk Fork Lake. Mercury was not detected in 40 of the 295 composites. The highest PCB concentration was $2100 \mu \mathrm{g} / \mathrm{kg}$ for golden redhorse suckers (Moxostoma erythrurum) from the Shenandoah River. Of the 295 composite samples collected, 213 did not have detectable levels of PCBs.

\section{Comparison by Feeding Type and Species}

Significant differences were tested for types of feeding fish for all species. Each species was grouped into three different feeding categories: mixed diet feeders, benthic feeders and predators (Table 1).

Mean values of mercury differed significantly between benthic $(103 \pm 9 \mu \mathrm{g} / \mathrm{kg})$ and predator $(249 \pm 15 \mu \mathrm{g} / \mathrm{kg})$ species, however, mixed diet feeders $(79 \pm 20 \mu \mathrm{g} / \mathrm{kg})$ were not significantly different from benthic feeders, but were significantly different from predator species (Figure 2). Mean concentrations of PCBs were significantly lower in predator species 
$(24 \pm 6 \mu \mathrm{g} / \mathrm{kg})$ than in benthic species $(120 \pm 30 \mu \mathrm{g} / \mathrm{kg})$. Mixed diet feeders $(60 \pm 54 \mu \mathrm{g} / \mathrm{kg})$ did not have significantly different mean concentrations from benthic or predator species (Figure 3). Pair wise comparisons were made for all species for mercury and PCB concentrations. Thirty two species were examined and species with significant differences are indicated in Figure 4, Table 2 (Mercury) and Figure 5, Table 3 (PCBs).

Figure 4 clearly indicates the trend in mercury being greater in predator type species than either the benthic or mixed diet feeding types. Yellow bars indicate predatory type feeding and all predators are found to have greater mercury concentrations than the benthic or mixed diet feeders, with the exception of black crappie (Pomoxis nigromaculatus), sauger (Sander canadensis) longnose gar (Lepisosteus osseus) and flathead catfish (Pylodictis olivaris). Mixed diet and benthic feeding fish are clearly lower in mercury concentration and are not as obvious in the graph as the predators.

Polychlorinated biphenyl concentrations for different species found that benthic feeding fish had significantly greater PCB concentrations than mixed diet or predator feeding species. Bluegill (Lepomis macrochirus ) had the highest concentration of PCBs, followed by channel catfish, white bass (Morone chrysops) and golden redhorse sucker (Moxostoma erythrurum) before a noticeable drop in PCB concentrations to the predator feeding species (Figure 5).

Mean PCB concentrations were greatest in bluegill $(240 \pm 380 \mu \mathrm{g} / \mathrm{kg})$ followed by channel catfish $(190 \pm 45 \mu \mathrm{g} / \mathrm{kg})$. Mean PCB concentrations were non-detectable in fifteen species. Northern hog sucker (Hypentelium nigricans) had the lowest detectable PCB levels ( $4 \pm 15 \mu \mathrm{g} / \mathrm{kg}$ ). Figure 5 is not as clearly defined in relation to benthic, mixed diet and predator. The benthic species (green bars) appear to have higher concentrations of PCBs 
than do the predator or mixed diet species, but sunfish (mixed diet) captured at a known PCB impacted location is the highest concentration indicated on the graph.

The high levels of PCBs found in bluegill may have resulted from the high amounts of PCB concentrations found in the Shenandoah River (Figure 7). The highest individual measurement for PCBs in the state was the golden redhorse sucker from the Shenandoah River; therefore, the possible point source pollution in the Shenandoah River may have caused the bluegill species to have the greatest mean concentration of PCBs of all species represented in the state survey.

\section{Comparison by Watershed}

Pair wise comparisons were made for all watersheds for mercury and PCB concentrations. Of the 22 watersheds sampled for analysis, mean mercury concentrations were greatest in the Shenandoah River watershed $(350 \pm 150 \mu \mathrm{g} / \mathrm{kg})$, followed by the Middle Ohio Valley $(320 \pm 80 \mu \mathrm{g} / \mathrm{kg})$ and the Little Kanawha River $(270 \pm 34 \mu \mathrm{g} / \mathrm{kg})$. The Upper New River watershed had the lowest mean mercury concentration of $39 \pm 17 \mu \mathrm{g} / \mathrm{kg}$. Mean mercury concentrations were non-detectable in the North Carolina Hatchery fish that were collected before release into the West Virginia waterways (Figure 6, Table 4).

Mean PCB concentrations were also greatest in the Shenandoah River watershed (880 $\pm 485 \mu \mathrm{g} / \mathrm{kg}$ ). The Monongahela River was the next highest PCB concentrated watershed with $295 \pm 184 \mathrm{mg} / \mathrm{kg}$. The Lower New River watershed had the lowest PCB concentration with no detectable PCBs (Figure 7, Table 5).

\section{Discussion}

\section{Mercury}




\section{Species and Feeding Types}

Higher concentrations of mercury are expected in predator species than in ominivore or benthic species due to the slightly lipophilic nature of mercury (Newman et al. 2001). Burger (2001) found trends of mercury levels, similar to our study, in species tested in South Carolina. The study showed that largemouth bass had the highest mercury concentrations with a mean of $470 \mathrm{ug} / \mathrm{kg}$ (wet weight) in the edible tissue and in our study largemouth bass contained $288 \mathrm{ug} / \mathrm{kg}$ mercury and were among the highest level of mercury in all species. The South Carolina study did not sample walleye (Sanders vitreus) species, which contained the greatest mercury level of all species in our study. Walleye captured in our study were very large. This would indicate that the age of the walleye sampled would contribute to higher mercury values. Our study values were comparable to the mercury concentrations found in largemouth and smallmouth bass (Micropterus dolomieu) in freshwater surveys of Maryland by Gilmour and Riedel (2000). They found that largemouth bass contained between 160 and $490 \mathrm{ug} / \mathrm{kg}$ mercury in edible fillets, as compared to 288 in our study. Smallmouth bass were found to contain $250 \mathrm{ug} / \mathrm{kg}$ mercury, whereas our study reported 255 $\mathrm{ug} / \mathrm{kg}$ of mercury in smallmouth bass. Compared to our study, which found yellow perch (Perca flavescens) to have non-detectable levels of mercury, the Gilmour study found yellow perch (mixed diet feeder) to have lower mercury concentrations within similar watersheds, ranging from 150 to $180 \mathrm{ug} / \mathrm{kg}$ mercury (Gilmour et al. 2000).

A summary of mercury studies conducted in the Northeast United States correlated similar trends with the results reported in our study. As reported by Kamman et al. (2005), 24 mercury tissue studies were summarized and the results of these papers followed the same predator, benthic, mixed diet trend that was observed in our study. Comparable to our study, 
the Kamman et al. study reported walleye having the highest level of mercury with 759 $\mathrm{ug} / \mathrm{kg}$, followed by white perch $(718 \mathrm{ug} / \mathrm{kg})$, rock bass $(610 \mathrm{ug} / \mathrm{kg})$, smallmouth bass (589 $\mathrm{ug} / \mathrm{kg}$ ), sauger (573 ug/kg) and largemouth bass (535 ug/kg). Our study showed walleye having the greatest mercury concentrations $(420 \mu \mathrm{g} / \mathrm{kg})$ followed by saugeye $(330 \mathrm{ug} / \mathrm{kg})$, white bass (299 ug/kg), largemouth bass (288 ug/kg), smallmouth bass ( $255 \mathrm{ug} / \mathrm{kg})$ then spotted bass $(228 \mathrm{ug} / \mathrm{kg})$. Clearly, predators have the highest concentrations of mercury in most studies, despite differences within species.

The Kamman et al. (2005) report, like our study, also showed mixed diet and benthic feeding species having lower concentrations of mercury than predator species. This study reported rainbow trout (Oncorhynchus mykiss) having the lowest concentration $(86 \mathrm{ug} / \mathrm{kg})$, followed by sunfish (Lepomis) (166 ug/kg), brown bullhead (Ameiurus nebulosus) (172 $\mathrm{ug} / \mathrm{kg}$ ) and white sucker (186 ug/ $\mathrm{kg}$ ). Mixed diet feeding fish, such as black crappie, with 250 ug/ $/ \mathrm{kg}$ mercury, had concentrations in similar ranges to our mixed diet feeding fish. Benthic feeders, such as channel catfish, tended to have lower mercury concentrations, which compared to our findings. Our study did not detect mercury concentrations in yellow perch and bullhead catfish species. Rainbow trout had the lowest detectable levels of mercury (mean $=15 \mu \mathrm{g} / \mathrm{kg}$ ), followed by sucker species, bluegill, and channel catfish. Comparison of these studies with our studies shows that the trends for predators, benthic species, and omnivore are comparable across states and water bodies.

A study conducted by Cabana et al. (1994) found that both mercury and PCBs accumulated more in predator species than in the mixed diet and benthic species, but also found that bioaccumulation and biomagnification varied significantly from water body to water body. This variation could be attributed to different species found in one food chain 
that was missing in another food chain. Our study, however, should negate this affect because species were tested across several different types of water bodies and therefore, food chain variations should be accounted for in the sampling design. Also, Kamman et al. (2005) looked at the effects of the length of each species, the water body type, and the individual water body on mercury concentration within species. Our study looked at all species categorized into benthic, mixed diet and predator; therefore, water body type, individual water bodies and individual fish length are all represented within the mean for each feeding type.

In our study, individual analysis of mercury concentrations by species confirmed that predators had significantly greater mercury concentrations than benthic species. Walleye had the highest concentration of mercury, followed by saugeye, white bass, largemouth bass, spotted bass and yellow bullhead before a noticeable drop in mercury concentrations to the lower feeding species.

Mean mercury concentrations individual fish species indicate that predator type species do accumulate greater concentrations of mercury than mixed diet or benthic type feeders. Walleye, saugeye, white bass, and the Micropterus species (largemouth, smallmouth and spotted bass) had the greatest concentrations of mercury, respectively, which supports the findings of Burger et al. (2001). Our study also showed mixed diet species such as yellow perch, rainbow trout and benthic feeders such as the Moxostoma species (Silver redhorse sucker, black redhorse sucker) had the lowest concentration of mercury.

\section{PCBs}

Polychlorinated biphenyls contaminant concentrations followed the opposite trend as mercury, generally accumulating in the lower trophic level fish at higher concentrations than 
the higher predatory type fish. This is due to the lipophilic nature of PCBs and the diets of the benthic feeders (Kidd et al. 1998). We found benthic feeders fish (123 ug/kg) to have significantly higher concentrations of PCBs than predators (23 ug/kg). Benthic feeding fish had concentrations five times that of the predatory feeders, representing highly significant differences between these two feeding groups.

The level of PCBs in mixed diets did not differ significantly from benthic or predatory fish. Polychlorinated biphenyl concentrations in the mixed diet group were lower than predatory fish and higher then benthic feeding fish, following the same trend as mercury analysis. Mixed diet feeding fish were expected to accumulate less contaminants than either predatory or benthic type feeders. This is a result of not consuming one specific food type, but rather eating a varied diet that would cause the mixed diet type feeders to not concentrate any one type of contaminant.

In a study of several lakes in California, a similar trend to our results was found when analyzing similar fish species (Brodberg and Pollock 1999). In this study, two California lakes were analyzed for PCBs and other contaminants. Five species of fish (rainbow trout, channel catfish, carp, crappie and largemouth bass) were tested and the results are presented in wet weight means for each species. In the lakes that contained detectable levels of PCBs, channel catfish had the highest concentrations of PCBs, with nearly ten times the levels of PCBs found in largemouth bass. Carp, which are also benthic feeders, had high levels of PCBs compared to largemouth bass, rainbow trout and crappie. This study also looked at other organochlorine (organic compounds containing chlorine) pesticides and contaminants and found the highest levels in channel catfish, followed by carp, then rainbow trout, largemouth bass and then crappie. Although this survey did not include statistical analysis of 
the contaminants, it is clear to see the same trend in feeding types exists in this study as our study.

Rasmussen et al. (1990) found that PCB accumulation in benthic fish species was mainly dependant on the lipid levels of the fish. This suggests that fish containing higher levels of lipid stores will accumulate greater levels of PCBs and other non-polar organic contaminants. Channel catfish, carp, and the sucker species generally contain more lipid stores than most top level predators such as walleye, sauger and the bass species.

\section{Mercury and PCBs in Watersheds}

Considering watersheds examined in the present study, mercury is more evenly distributed throughout the state and PCB concentrations are not evenly distributed. It is possible that this contrasting distribution of concentrations for mercury and PCBs is due to the fact that mercury is a naturally occurring compound coupled with the fact that it is volatilized and deposited via air currents, therefore, it would likely be found in all watersheds throughout West Virginia. PCBs are manmade substances that were not meant to be released into the environment and are therefore considered more of a point source pollutant.

However, PCBs are distributed throughout the environment through various routes such as uptake in organisms, the movement through water and air, and the exchanges that occur from water and air exchange (Dachs et al. 1999, Bamford et al. 2002). Point sources of PCBs are still more influential in the distribution of PCBs in the waterways than the distribution of mercury, which occurs naturally and is anthropogenic non-point source pollution (Jernelöv and Lann 1971).

It is interesting to note that the watersheds found in the southern part of the state contained lower mercury concentrations than the watersheds found in the northern part of the 
state with the exception of the Monongahela River and the North Branch of the Potomac River watershed (Figure 6, Table 4). As previously discussed, coal burning power plants are a large source of mercury contamination and even though mercury pollution can travel in the upper atmosphere very long distances, it stands to reason, that areas with higher concentrations of coal fired power plants should have more mercury contamination in close proximity to the sources. Our study shows a higher level of mercury fish tissue contamination closer to urban areas such as those in the northern part of the state, near Pittsburgh PA, and Washington, DC, and as previously mentioned, the chlorine plant located in Natrium, WV, may affect local mercury concentrations in fish tissue in northern West Virginia.

In our study, yellow perch and rainbow trout both contained very low concentrations of mercury and PCBs. This may be due to the fact that both of these species are regularly removed from the watershed as recreational favorites, which could reduce their exposure time to the chemicals. In addition, diet for both these species may contribute to the lower concentrations of mercury and PCBs, since both species feed on a variety of different prey. However, these concepts are not supported by observations made in redhorse suckers and white bass, as concentrations of contaminants in either species cannot be explained by diet. Redhorse suckers feed predominately as benthic feeders which fail to explain the relatively high levels of mercury in the fish. Likewise, white bass do not feed exclusively on either benthic or aquatic prey so the high concentrations found in this species cannot be explained by fish diet.

\section{Conclusion}


Mercury concentrations were highest in predator species and PCB concentrations were highest in the benthic feeding group as expected. For mercury, benthic feeding fish and mixed diet feeding fish were not different, but mixed diet feeding fish had lower concentrations than predator feeding fish. This supports the idea that mercury is accumulated at greater concentrations in predator fish. For PCBs, predator feeding fish had the lowest concentrations of PCBs, and benthic feeders had the highest concentrations of PCBS, however, mixed diet feeding fish were not significantly different from either the predator or the benthic fish.

Differences among species were comparable to those found between the feeding types, with most predator species containing greater concentrations of mercury and lower concentrations of PCBs and benthic feeding species containing higher PCB concentrations and lower mercury concentrations than predator fish, with most mixed diet species being between the other two feeding types for both contaminants.

Overall, mercury and PCB concentration in fish tissues exists throughout the state and in various species. Fish tissues in all watersheds contained either high amounts of mercury or PCBs with only a few watersheds being low in both. These results may be skewed, however, based on the different species collected for individual sites.

The mercury and PCB contamination throughout the state suggests that there are more contaminants present in the fish tissue in West Virginia waters. More research is needed to determine which fish contain safer levels of contaminants. This study gives good indication of which fish are safer to consume based on location of the fish and the feeding type of the fish to be consumed. 


\section{References}

Agency for Toxic Chemicals and Disease Registry. 1998. Toxicological Profile for Mercury Draft. ATSDR. Atlanta, GA.

Baker JE, Eisenreich SJ, Johnson TC, Halfman BM. 1985. Chlorinated hydrocarbon cycling in the benthic nepheloid layer of Lake Superior. Environmental Science Technology. 19: 854-861.

Bamford HA, Ko FC, Baker JE. 2002. Seasonal and annual air-water exchange of polychlorinated biphenyls across Baltimore Harbor and the northern Chesapeake Bay. Environmental Science Technology. 36: 4245-4252.

Borga K, Gabrielsen GW, Skaare JU. 2001. Biomagnification of organochlorines along a Barents sea food chain. Environmental Pollution. 113: 087-198.

Brodberg RK, Pollock GA. 1999. Prevalence of selected target chemical contaminants in sport fish from two California lakes: Public health designed screening study. EPA Assistance Atreement No. CX 825856-01-0.

Bruner KA, Fisher SW, Landrum PF. 1994. The role of the zebra mussel, (Dreissena polymorpha), in contaminant cycling. II. Zebra mussel contaminant accumulation from algae 
and suspended particles, and transfer to the benthic invertebrate, Gammarus fasciatus. Journal of Great Lakes Research, 20: 735-750.

Burger J, Gaines K, Boring S, Stephens W, Snodtrass J, Gochfeld M. 2001. Mercury and Selenium in fish fromt eh Savannah River: species, trophic level, and locational differences. Env Res. Sec. A 87: 108-118.

Cabana G, Trembly A, Kalff J, Rasmussen JB. 1994. Pelagic food chain structure in Ontario Lakes: A determinant of mercury levels in lake trout (Salvelinus namaycush) Cnandian Journal of Fisheries and aquatic Science. 51: 381-389.

Carpi A. 1997. Mercury from combustion sources: A review of the chemical species emitted and their transport in the atmosphere. Water, Air, and Soil Pollution. 98:241-254.

Clarkson T. 1993. Mercury: major issues in environmental health. Environ Health Perspect. 100:31-38.

Clements WH, Oris JT, Wissing TE. 1994. Accumulation and food chain transfer of fluoranthene and benzo[a]pyrene in Chironomus riparius and Lepomis macrochirus. Arch. Environ. Contam. Toxicol. 26: 261-266.

Dachs J, Eisenreich S, Baker J, Ko FC, Jeremiason J. 1999. Coupling of phytoplankton uptake and air-water exchange of persistent organic pollutants. Environmental Science Technology. 33: 3653-3660.

Eisler R. 1987. Polychlorinated Biphenyls Hazards to Fish, Wildlife, and Invertebrates: A Synoptic Review. U.S. Fish and Wildlife Service Biological Report 85(1.7). Washington D.C.

Eisler R. 1986. Mercury Hazards to Fish, Wildlife, and Invertebrates: A Synoptic Review. U.S. Fish and Wildlife Service Biological Report 85(1.10). Washington D.C.

Fein GG, Jacobson JL, Jacobson SW, Schwartz PM, Dowler JK. 1994. Prenatal exposure to polychlorinated biphenyls: effects on birth size and gestational age. The Journal of Pediatrics 105(2): 315-320.

Giesy J, Kurunthachalam K. 1998. Dioxin-like and non-dioxin-like toxic effects of Polychlorinated Biphenyls (PCBs): Implications for risk assessment. Critical Reviews in Toxicology. 28(6): 511-569.

Gilmour CC, Riedel GS. 2000. A Survey of Size-Specific Mercury Concentrations in Game Fish from Maryland Fresh and Estuarine Waters. Archives of Environmental Contamination and Toxicology. 39: 53-59. 
Gobas FAPC, Wilcockson JB, Russell RW, Haffner GD. 1999. Mechanism of biomagnification in fish under laboratory and field conditions. Evniron Sci Technol. 33: 133-141.

Gore A, Wu J, Oung T, Lee J, Woller M. 2002. A Novel Mechanism for EndocrineDisrupting Effects of Polychlorinated Biphenyls: Direct Effects on Gonadotropin-Releasing Hormone Neurones. Journal of Neuroendocrinlogy. 14: 814-823.

Hammond A. 1972. Chemical Pollution: Polychlorinated Biphenyls. Science 175(4018): 155-156.

Hawker DW and Connell DW. 1988. Octanol-Water partition coefficients of polychlorinated biphenyl congeners. Envirom Sci Technol 22: 382-387.

Hellou J, Mackay D, Banoub JH. 1998. Dietary and aqueous exposure of finfish to organochlorine compounds: A case study. Archives of Environmental Contaimination and Toxicology. 34: 280-288.

Hellou J, Leonard J, Anstey C. 2002. Dietary exposure of finfish to aromatic contaminants and tissue distribution. Archives of Environmental Contaimination and Toxicology. 42(4): 470-476.

Hill W and Napolitano G. 1997. PCB Congener accumulation by periphyton, herbivores, and omnivores. Archives of Environmental Contaimination and Toxicology. 32: 449-455.

Jackson J. 1996. Contrast of constant and bioenergetics-based assimilation efficiency in describing ecosystems. Ecological Applications. 6: 1355-1364

Jernelöv A, Lann H. 1971. Mercury accumulation in food chains. Oikos 22(3): 403-405.

Jobling M. 1996 Environmental Biology of Fishes. Chapman and Hall, London.

Kamman N C, Burgess NM, Driscoll C T, Simonin H A, Godale W, Linehan J, Estabrook R, Jutcheson M, Major A, Scheuhammer AM and Scruton DA. 2005. Mercury in freshwater fish o Northeast North America - A geographic perspective based on fish tissue monitoring databases. Ecotoxocity. 14: 163-180.

Karickhoff SW, Bromn D S and Scott TA. 1979. Sorption of hydrophobic pollutants on natural sediments. Water Resources. 13: 241-248.

Kay DP, Blankenship AL, Coady KK, Neigh AM, Zwiernik MJ, Millsap SD, Strause K, Park C, Bradley P, Newsted JL, Jones PD and Giesy JP. 2005. Dirrerntial Accumulation of Polychlorinated Biphenyl Congeners in the Aquatic Food Web at the Kalamazoo River Superfund Site, Michigan. Environmental Science Technology. 39: 5964-5974. 
Kidd KA, Schindler DW, Hesslein RH and Muir CG. 1998. Affects of trophic position lipid on organochlorine concentrations in fishes from subartic lakes in Yokon Territory. Canadian Journal of Fisheries and Aquatic Science. 55: 869-881.

Kruse G and Scarnecchia D. 2002. Assessment of bioaccumulated metal and organochlorine compounds in relation to physiological biomarkers in Kootenai River white sturgeon. Journal of Applied Ichthyology. 18: Issue 4-6: 430-438.

Lindberg SE and Turner RR. 1977. Mercury emissions from chlorine-production solid wastes deposits. Nature. 268:133-136.

Lundebye A-K, Berntssen MHG, Lie O, Ritchie G, Isosaari P, Kiviranta H, Vartiainen T. 2004. Dietary uptake of dioxins (PCDD/PCDFs) and dioxin-like PCBs in Atlantic salmon (Slmo salar). Aquaculture Nutrition. 10: 199-207.

Mendola P, Buck G, Vena J, Zielezny M and Sever L. 1995. Consumption of PCBcontaminated sportfish and risk of spontaneous fetal death. Environmental Health Perspectives 103(5): 498-502.

Miller M, Wasik L. 1985. Relationships between octanol-water partition coefficient and aqueous solubility. Environmental Science Technology. 19(6): 522-529.

McKim J, Heath E. 1983. Dose determinations for waterborne 2, 5, 2', 5'-[14C] tetrachlorobiphenyl and related pharmacokinetics in two species of trout (Salmo gairdneri and Salvelinus fontinalis): A mass-balance approach. Toxicol Appl Pharmacol. 68: 177187.

National Research Council. 2000. Toxicological Effects of Methylmercury. National Academy Press. Washington, D.C. 289 Pages.

Newman MC, Roberts MH and Hale RC. 2001. Costal and Estuarine Risk Assessment. CRC Press. Boca Raton, FL. 128-133.

Oberdorf T, Guilbert E, Lucchetta J-C. 1993. Patterns of fish species richness in the Seine River basin, France. Hydrobiologia. 259: 157-167.

O'Reilly N, Ehlinger T, Shaker R. 2007. The Development and Evaluation of Methods for Quantifying Risk to Fish in Warm-water Streams of Wisconsin Using Self-Organized Maps: Influences of Watershed and Habitat Stressors. Technical Report No. 14. Center for Urban Environmental Studies, US EPA/NSF/USDA STAR Watershed Program, Northeastern University, Boston, MA

Pelletier C, Imbeault P,Tremblay A. 2003. Energy balance and pollution by organochlorines and polychlorinated biphenyls. The International Association for the Study of Obesity. Obesity Reviews. 4: 17-24. 
Power M, Klein GM, Guiguer KRRA, Kwan MKH. 2002. Mercury accumulation in the fish community of a sub-Arctic lake in relation to trophic position and carbon sources. Journal of Applied Ecology. 39: 819-830.

Rasmussen J B, Rowan DJ, Lean DRS, Carey JH. 1990. Food chain structure in Ontario Lakes determines PCB levels in lake trout (Salvelinus namaycush) and other pelagic fish. Canandian Journal of Fisheries and aquatic Science. 47: 2030-2038.

SAS Institute, Inc. 1989. SAS User's Guide: Statistics, Version 6.06. SAS Institute, Inc. Cary, NC.

Swain WR. 1988. Human health consequences of consumption of fish contaminated with organochlorine compounds. Aquatic Toxicology 11: 357-377.

U.S. Environmental Protection Agency. 1992. Test Methods for Evaluating Solid Wastes : Physicals Chemical Methods. USEPA, USEPA Office of Solid Wastes and Emergency Response, Washington, D.C.

U.S. Environmental Protection Agency. 1995. Guidance for Assessing Chemical Contaminant Data for Use In Fish Consumption Advisories, Volume I: Fish Sampling and Analysis. USEPA, USEPA 823-R-95-007, Washington, D.C.

U.S. Environmental Protection Agency. 1997. Guidance for Assessing Chemical Contaminant Data for Use in Fish Consumption Advisories, Volume II: Risk Assessment and Fish Consumption Limits. USEPA, USEPA 823-B-97-009, Washington, D.C.

U.S. Environmental Protection Agency. 1998. Integrated Risk Information System Methylmercury (MeHg) CARSRN 22967-92-6 December 1, 1998.

U.S. Environmental Protection Agency. 1999. Mercury Update: Impact on Fish Consumption Advisories. USEPA, USEPA-823-F-99-016, Washington, D.C.

Voice TC, Webber Jr, WJ. 1983. Sorption of hydrophobic compounds by sediment soils and suspended solids. Theory and Background. Water Resources. 17: 1433-1441.

Wang Q, Kim D, Dionysiou DD, Sorial GA, Timberlake D. 2004. Sources and remediation for mercury contamination in aquatic systems-a literature review. Environmental Pollution. 131: 323-336.

Ward SM, Neumann RM. 1999. Seasonal Variations in Concentrations of Mercury in Axial Muscle Tissue of Largemouth Bass. North American Journal of Fisheries Management. 19: 89-96.

Warnick WA. December 2002. Sportfish consumption advisory for West Virginia. MS Thesis, West Virginia University, Morgantown, West Virginia. http://etd.wvu.edu/templates/showETD.cfm?recnum=2681. 
Zhou H, Wong M. 2000. Mercury accumulation in freshwater fish with emphasis on the dietary influence. Water Resources. 34(17): 4234-4242. 


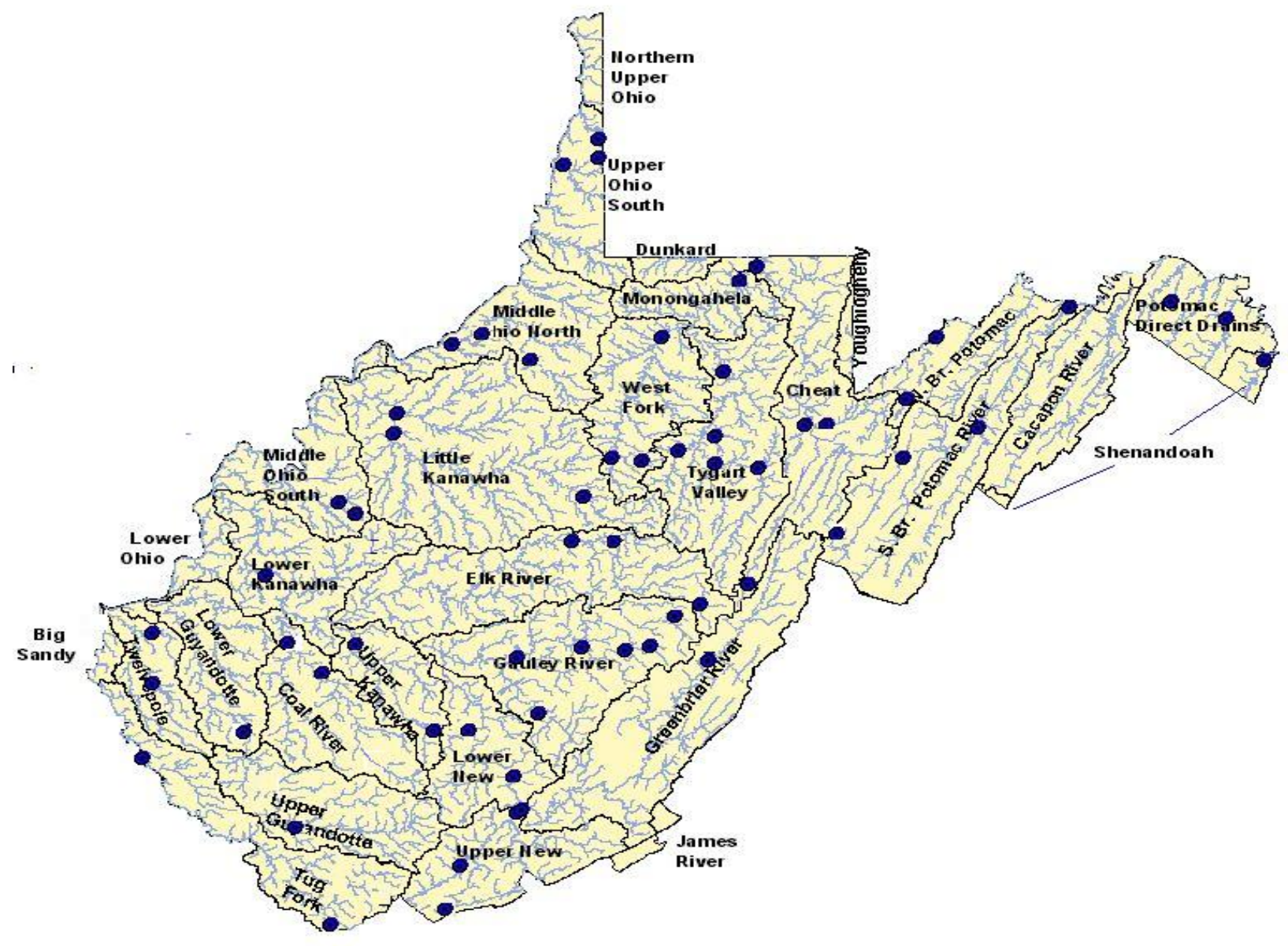

Figure 1. Sample sites for WV statewide consumption survey. Selected by WVDNR to represent all major watersheds and species types 


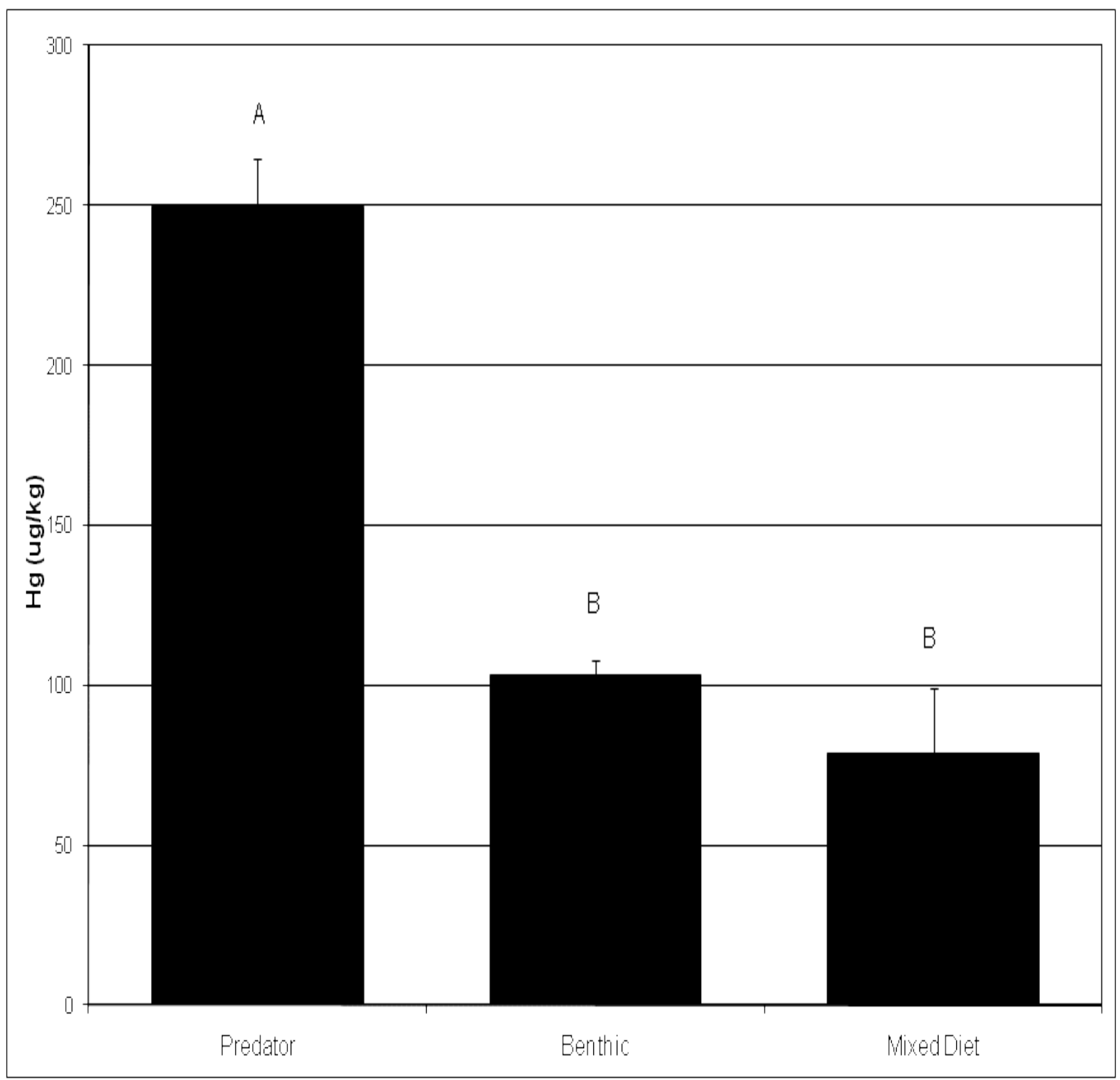

Figure 2. Mean mercury concentration ( $\mathrm{ug} / \mathrm{kg}$ ) of predator, benthic, and mixed diet fish for all fillet composites analyzed. Different letters indicate statistically significant difference. Error bars denote standard error of the mean. 


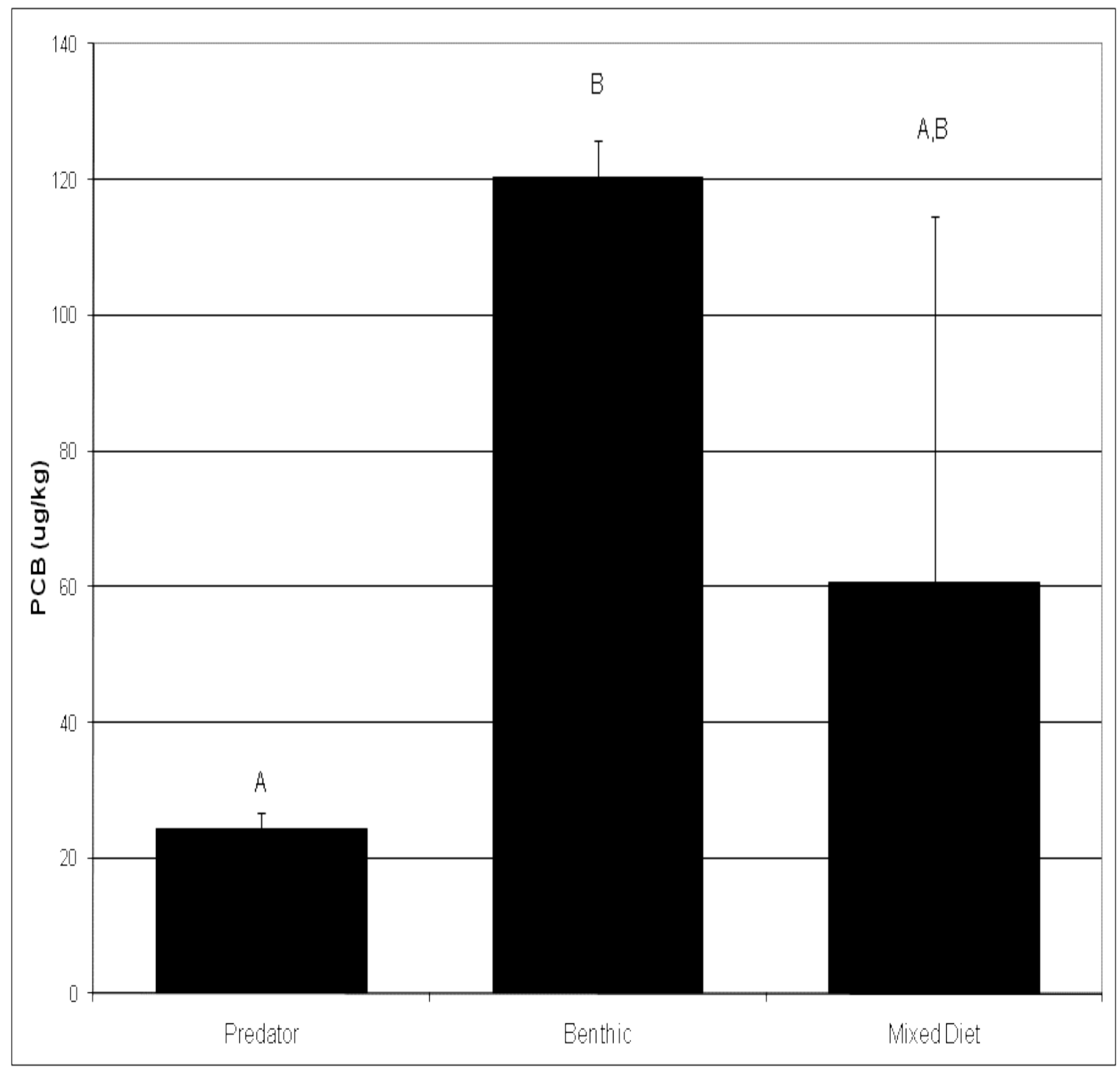

Figure 3. Mean PCB concentrations ( $\mathrm{ug} / \mathrm{kg}$ ) of predator, benthic, and mixed diet fish for all fillet composites analyzed. Different letters indicate statistically significant difference. Error bars denote standard error of the mean. 


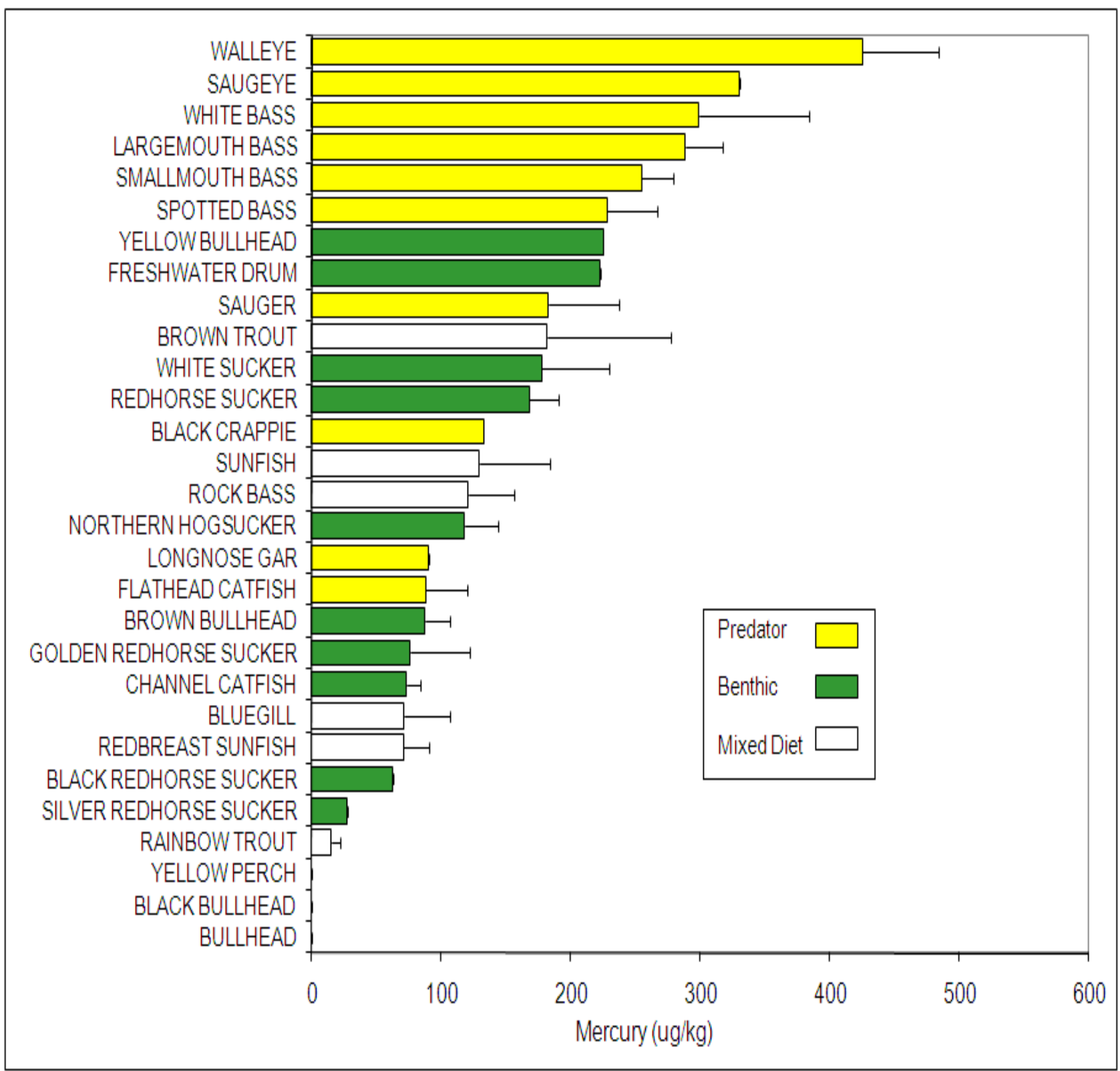

Figure 4. Mean mercury concentration for fish species, lowest concentration to highest. Error bars denote standard error of the mean. 


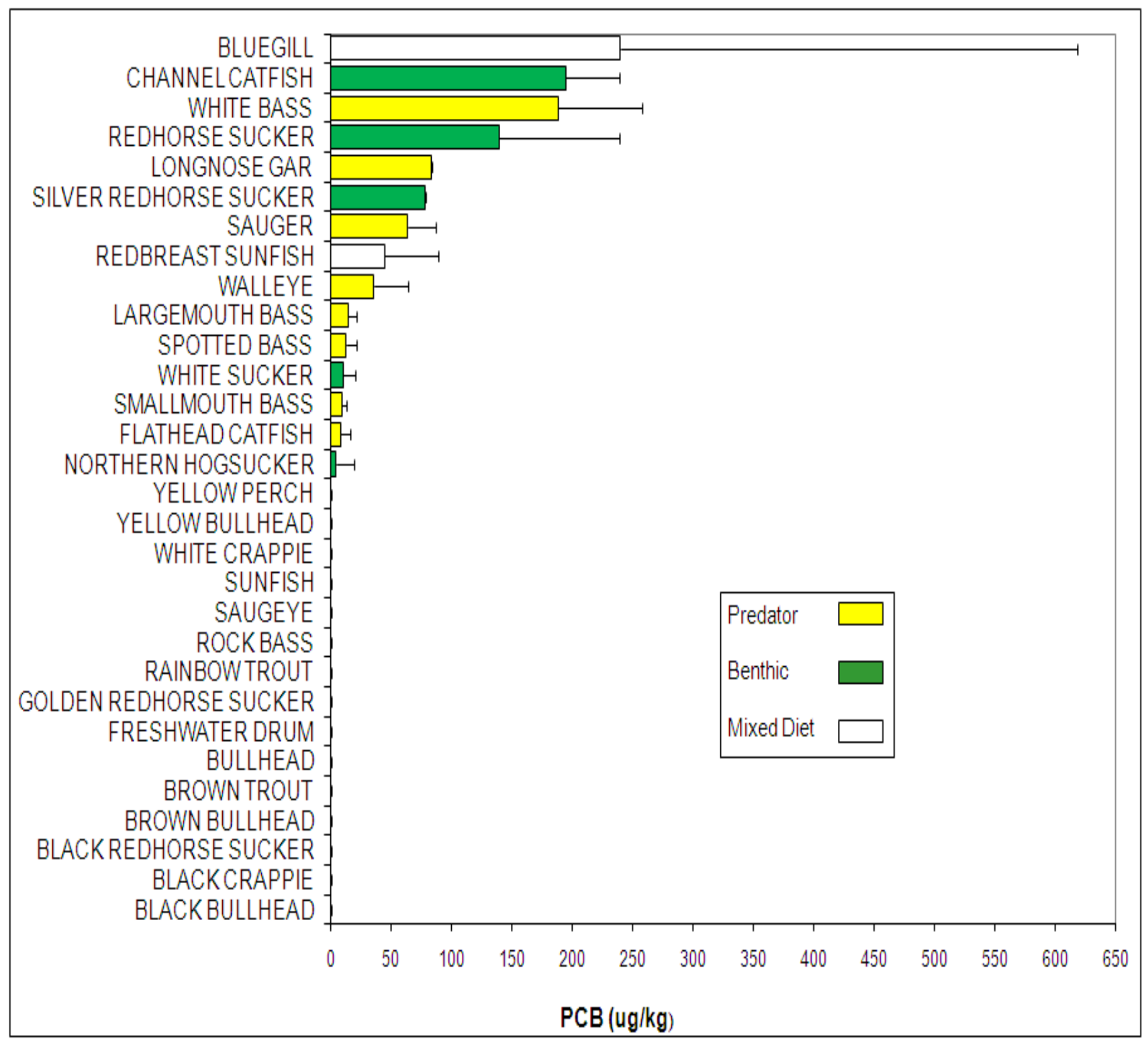

Figure 5. Mean PCB concentration for fish species, lowest concentration to highest. Error bars denote standard error of the mean. 


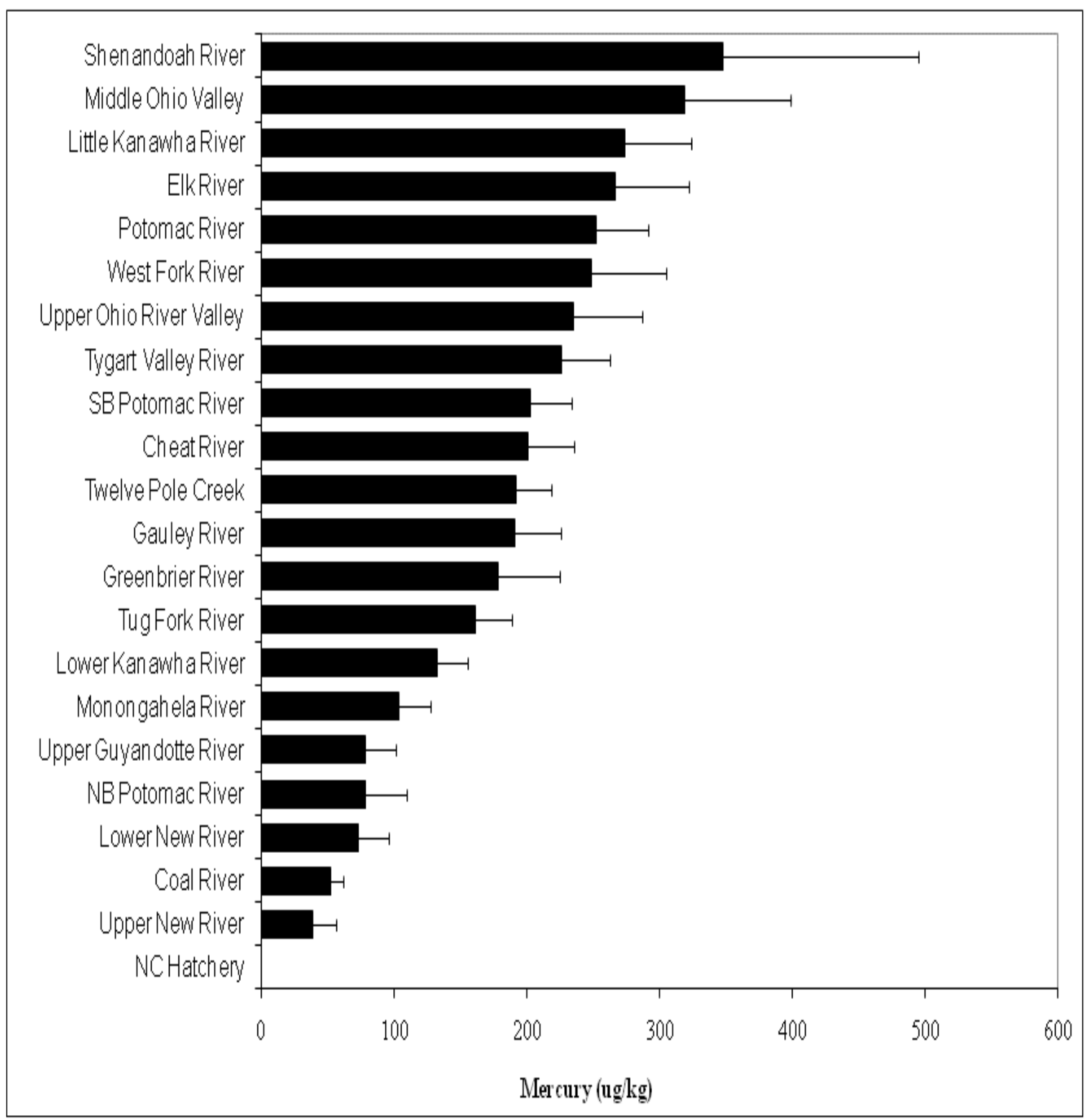

Figure 6. Mean mercury concentrations of composite fillets compared by watershed. Each watershed includes all species of all sizes within a watershed. Error bars denote standard error of the mean. 


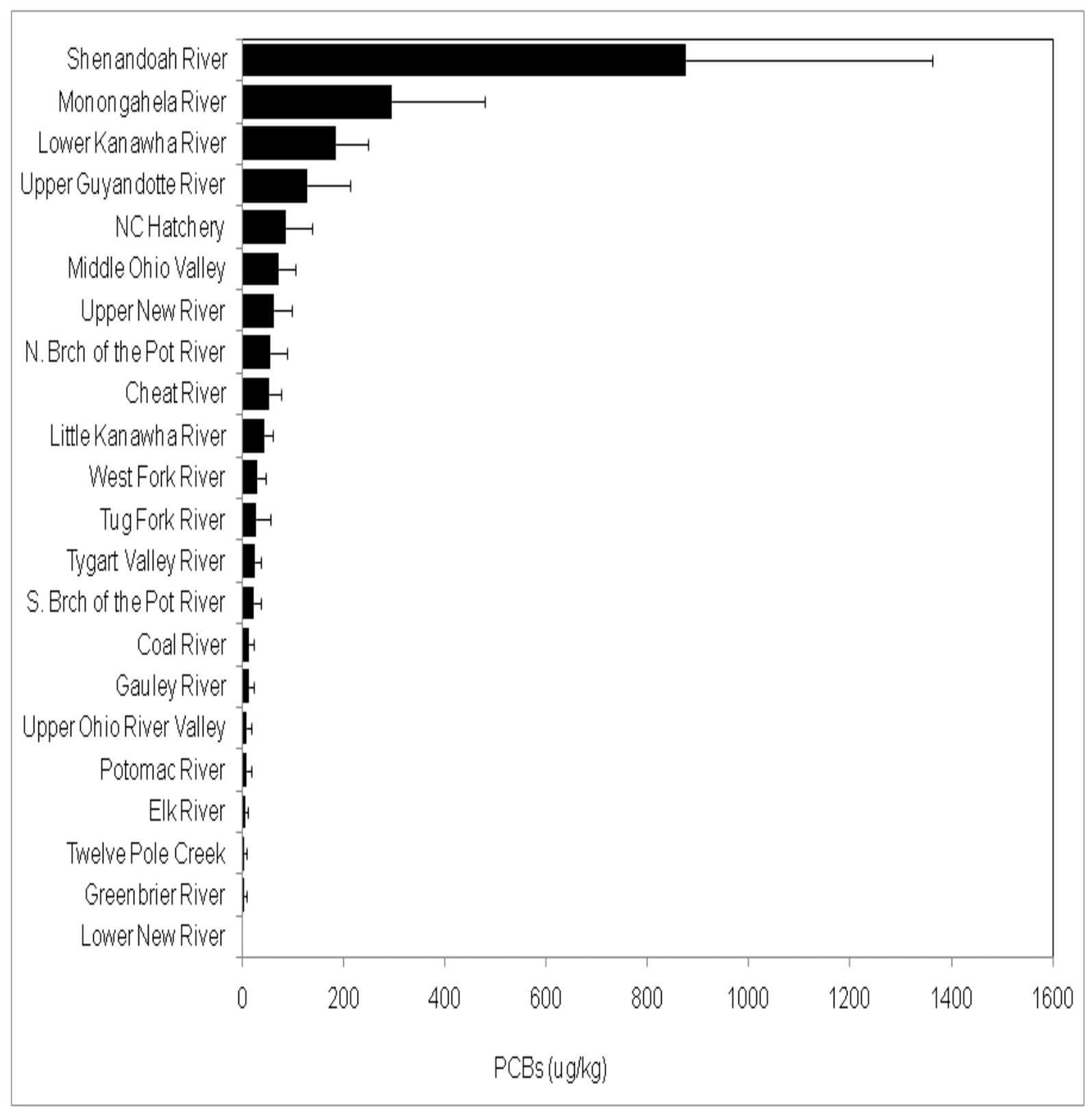

Figure 7. Mean PCB value of composite fillets compared by watershed. Each watershed includes all species of all sizes within a watershed. Error bars denote standard error of the mean. 
Table 1. Species catergorized as benthic, predator, mixed diet.

\begin{tabular}{|l|l|l|}
\hline Benthic Species & Predator Species & Mixed diets \\
\hline BLACK BULLHEAD & BLACK CRAPPIE & BLUEGILL \\
\hline BLACK REDHORSE SUCKER & FLATHEAD CATFISH & BROWN TROUT \\
\hline BROWN BULLHEAD & LARGEMOUTH BASS & RAINBOW TROUT \\
\hline BULLHEAD & LONGNOSE GAR & REDBREAST SUNFISH \\
\hline CHANNEL CATFISH & SAUGER & ROCK BASS \\
\hline FRESHWATER DRUM & SAUGEYE & SUNFISH \\
\hline GOLDEN REDHORSE SUCKER & SMALLMOUTH BASS & \\
\hline NORTHERN HOGSUCKER & SPOTTED BASS & \\
\hline REDHORSE SUCKER & WALLEYE & \\
\hline SILVER REDHORSE SUCKER & WHITE BASS & \\
\hline WHITE SUCKER & & \\
\hline YELLOW BULLHEAD & & \\
\hline YELLOW PERCH & & \\
\hline & & \\
\hline & & \\
\hline
\end{tabular}


Table 2. Mean mercury concentrations for species with standard error (SE) of the mean

\begin{tabular}{|l|r|r|}
\hline SPecies & \multicolumn{1}{|c|}{$\begin{array}{l}\text { Mean } \\
\text { ug/kg }\end{array}$} & \multicolumn{1}{c|}{ SE } \\
\hline BULLHEAD & 0.0 & 0 \\
\hline BLACK BULLHEAD & 0.0 & 0 \\
\hline YELLOW PERCH & 0.0 & 0 \\
\hline RAINBOW TROUT & 15.0 & 7 \\
\hline SILVER REDHORSE SUCKER & 27.5 & 0 \\
\hline BLACK REDHORSE SUCKER & 62.5 & 0 \\
\hline REDBREAST SUNFISH & 70.8 & 19 \\
\hline BLUEGILL & 71.0 & 35 \\
\hline CHANNEL CATFISH & 72.9 & 11 \\
\hline GOLDEN REDHORSE SUCKER & 76.1 & 46 \\
\hline BROWN BULLHEAD & 87.5 & 19 \\
\hline FLATHEAD CATFISH & 87.9 & 32 \\
\hline LONGNOSE GAR & 90.0 & 0 \\
\hline NORTHERN HOGSUCKER & 117.9 & 26 \\
\hline ROCK BASS & 120.5 & 36 \\
\hline SUNFISH & 129.4 & 55 \\
\hline BLACK CRAPPIE & 132.5 & 0 \\
\hline REDHORSE SUCKER & 168.1 & 23 \\
\hline WHITE SUCKER & 177.6 & 52 \\
\hline BROWN TROUT & 181.7 & 96 \\
\hline SAUGER & 182.8 & 55 \\
\hline FRESHWATER DRUM & 222.5 & 0 \\
\hline YELLOW BULLHEAD & 225.0 & 0 \\
\hline SPOTTED BASS & 228.0 & 38 \\
\hline SMALLMOUTH BASS & 254.5 & 25 \\
\hline LARGEMOUTH BASS & 288.3 & 29 \\
\hline WHITE BASS & 298.9 & 85 \\
\hline SAUGEYE & 330.0 & 0 \\
\hline WALLEYE & 425.2 & 59 \\
\hline & & \\
\hline
\end{tabular}


Table 3. Mean PCB concentrations for species with standard error of the mean

\begin{tabular}{|c|c|c|}
\hline Species & $\begin{array}{c}\text { Mean PCBs } \\
\text { ug/kg }\end{array}$ & SE \\
\hline BLACK BULLHEAD & 0.0 & 0 \\
\hline BLACK CRAPPIE & 0.0 & 0 \\
\hline BLACK REDHORSE SUCKER & 0.0 & 0 \\
\hline BROWN BULLHEAD & 0.0 & 0 \\
\hline BROWN TROUT & 0.0 & 0 \\
\hline BULLHEAD & 0.0 & 0 \\
\hline FRESHWATER DRUM & 0.0 & 0 \\
\hline GOLDEN REDHORSE SUCKER & 0.0 & 0 \\
\hline RAINBOW TROUT & 0.0 & 0 \\
\hline ROCK BASS & 0.0 & 0 \\
\hline SAUGEYE & 0.0 & 0 \\
\hline SUNFISH & 0.0 & 0 \\
\hline WHITE CRAPPIE & 0.0 & 23 \\
\hline YELLOW BULLHEAD & 0.0 & 0 \\
\hline YELLOW PERCH & 0.0 & 0 \\
\hline NORTHERN HOGSUCKER & 4.1 & 15 \\
\hline FLATHEAD CATFISH & 8.1 & 8 \\
\hline SMALLMOUTH BASS & 9.1 & 4 \\
\hline WHITE SUCKER & 10.3 & 10 \\
\hline SPOTTED BASS & 12.8 & 8 \\
\hline LARGEMOUTH BASS & 14.1 & 8 \\
\hline WALLEYE & 35.5 & 28 \\
\hline REDBREAST SUNFISH & 44.6 & 45 \\
\hline SAUGER & 63.5 & 24 \\
\hline SILVER REDHORSE SUCKER & 78.0 & 0 \\
\hline LONGNOSE GAR & 83.4 & 0 \\
\hline REDHORSE SUCKER & 139.0 & 100 \\
\hline WHITE BASS & 188.3 & 69 \\
\hline CHANNEL CATFISH & 194.3 & 45 \\
\hline BLUEGILL & 239.4 & 378 \\
\hline
\end{tabular}


Table 4. Mean mercury concentrations of fishes by watershed with standard error (SE) of the mean

\begin{tabular}{|c|c|c|}
\hline Sample Location & $\begin{array}{c}\text { Mean Hg } \\
\mathrm{ug} / \mathrm{kg}\end{array}$ & SE \\
\hline NC Hatchery & 0.0 & 0 \\
\hline Upper New River & 38.9 & 12 \\
\hline Coal River & 51.9 & 15 \\
\hline Lower New River & 73.1 & 21 \\
\hline NB Potomac River & 78.2 & 24 \\
\hline Upper Guyandotte River & 78.8 & 25 \\
\hline Monongahela River & 104.0 & 33 \\
\hline Lower Kanawha River & 132.0 & 33 \\
\hline Tug Fork River & 161.0 & 93 \\
\hline Greenbrier River & 177.9 & 49 \\
\hline Gualey River & 191.3 & 42 \\
\hline Twelvepole Creek & 191.6 & 48 \\
\hline Cheat River & 201.2 & 39 \\
\hline SB Potomac River & 203.0 & 40 \\
\hline Tygart Valley River & 226.4 & 45 \\
\hline Upper Ohio River Valley & 235.3 & 74 \\
\hline West Fork River & 248.7 & 64 \\
\hline Potomac River & 252.5 & 103 \\
\hline Elk River & 266.6 & 77 \\
\hline Little Kanawha River & 273.7 & 60 \\
\hline Middle Ohio Valley & 319.0 & 92 \\
\hline Shenandoah River & 347.5 & 174 \\
\hline
\end{tabular}


Table 5. Mean PCB concentrations of fishes by watershed with standard error (SE) of the mean

\begin{tabular}{|c|c|c|}
\hline Sample Location & $\begin{array}{c}\text { Mean PCB } \\
\text { ug/kg }\end{array}$ & SE \\
\hline Lower New River & 0.0 & 0 \\
\hline Greenbrier River & 4.1 & 4 \\
\hline Twelve Pole Creek & 4.8 & 3 \\
\hline Elk River & 5.2 & 5 \\
\hline Potomac River & 8.6 & 9 \\
\hline Upper Ohio River Valley & 9.2 & 9 \\
\hline Gauley River & 13.4 & 10 \\
\hline Coal River & 14.4 & 8 \\
\hline S. Brch of the Pot River & 23.7 & 12 \\
\hline Tygart Valley River & 25.8 & 12 \\
\hline Tug Fork River & 27.8 & 28 \\
\hline West Fork River & 29.2 & 16 \\
\hline Little Kanawha River & 44.1 & 17 \\
\hline Cheat River & 54.0 & 23 \\
\hline N. Brch of the Pot River & 55.2 & 34 \\
\hline Upper New River & 62.2 & 35 \\
\hline Middle Ohio Valley & 72.7 & 32 \\
\hline NC Hatchery & 87.0 & 50 \\
\hline Upper Guyandotte River & 128.0 & 84 \\
\hline Lower Kanawha River & 184.8 & 65 \\
\hline Monongahela River & 295.4 & 184 \\
\hline Shenandoah River & 876.5 & 486 \\
\hline
\end{tabular}


Chapter 2

Effects of Season and Gender on Fish Tissue Contamination Levels 


\section{Introduction}

Chemical contamination of the environment is of growing concern, as many contaminants can have a negative effect on human health. For example, the public may directly consume contaminants found in fish tissue. Polychlorinated biphenyls (PCBs) are lipophilic contaminants of particular concern, as these compounds bio-accumulate in the fat stores of the animal. Ingestion of the contaminated fish tissue can result in bioaccumulation of the contaminant in humans, which may lead to serious health concerns not only to adults, but also to infants and children.

Warnick (2000) reported mercury and PCBs in most streams in West Virginia and these data resulted in the formation of a West Virginia Sport Fish Consumption Advisory Guide. The consumption advisories resulting from the Sport Fish Consumption Advisory Guide address the current state of contaminant concentrations within West Virginia; however, new questions concerning contaminant concentrations in fish tissue have risen. Areas of concern are whether concentration of contaminants will change due to season and if this change is tied to the fish's reproductive cycle.

Organic contaminants have differing chemical properties that affect the manner in which the chemical will travel through and are stored in the environment. These physiochemical properties include aqueous solubility, polarity, hydrophobicity, lipophilicity and molecular structure of the chemical (Reid et al. 2000). One important chemical property of organic contaminants is referred to as the octanol-water partition coefficient $\left(\mathrm{K}_{\mathrm{ow}}\right)$ (Hawker and Connell 1988). The water to lipid solubility, represented by $\mathrm{K}_{\mathrm{ow}}$, is the octanol-water partition coefficient, which plays a major role in how the chemical reacts in the environment and how it is taken up and available to an organism. The $\mathrm{K}_{\mathrm{ow}}$ values are important in 
understanding the ability of the compound to dissolve in water or accumulate in lipid stores of animals and fish (Hawker and Connell 1988). Organochlorine contaminants are chlorinated organic compounds that share similar physiochemical properties, such as higher $\mathrm{K}_{\mathrm{ow}}$ values, low polarity and lipid solubility. Polychlorinated biphenyls are a type of organochlorine compound.

Contaminant levels will increase in concentration as they are concentrated up the aquatic food chain, even affecting mammals and birds (Hill and Napolitano 1997, Froese et al. 1998 and Borga et al. 2001) and eventually humans (Grandjean et al. 1995). Lipophilic compounds such as PCBs and other organic contaminants accumulate in the fat of fish. Fat accumulation, water column levels, time of exposure, diet, age of fish, metabolism/elimination of the contaminant and other characteristics of the aquatic environment can affect the concentration of PCBs in tissue (Jandacek and Tso 2001).

Polychlorinated biphenyls are persistent toxic and carcinogenic environmental contaminants. They can bioaccumulate through the aquatic food chain into fish to concentrations from 2000 to over a million times greater than the ambient water (USEPA 1999). Polychlorinated biphenyls are a group of 209 isomers of synthetic halogenated hydrocarbons that were formulated in 1881 and sold in various mixtures under the trade name Aroclor. Aroclor mixtures of PCBs were differentiated with numbers designating the mixtures chlorination and subsequent pattern. Polychlorinated biphenyls were used for heat transfer agents, lubricant, dielectric agents, flame retardants, plasticizers, and waterproofing materials (Eisler 1986). Polychlorinated biphenyls were first synthesized in Germany, produced in Europe, and later produced in the United States. They were banned from production in the USA in the 1970's, however production in Europe and Russia continued 
until the 1990's (Giesy and Kurunthachalam 1998). Since 1971, PCBs have been used only for insulation or cooling in closed electrical components. The Toxic Substances Control Act of 1979 banned the manufacture processing, distribution, and use of PCBs except in totally enclosed systems because they are fat soluble, extremely persistent and will bioaccumulate in the environment. However, due to indiscriminate disposal and atmospheric transport, PCB residues are found worldwide.

Polychlorinated biphenyls are persistent in nature, slow to degrade, non-volatile, and have low water solubility (USEPA 1999, Pelletier et al. 2003). PCB's are highly lipophilic, and accumulate in the fat of organisms. Accumulation of chemical compounds in an organism is referred to as bioaccumulation of the contaminant. Bioaccumulation of the contaminant results in biomagnification, which is an increase in the contaminant concentration in animals higher in the food chain (Kruse and Scarnecchia 2002, Kunisue et al. 2002, Pelletier et al. 2003). Biomagnification of contaminants in the food chain has been shown to cause a variety of diseases in vertebrates (Jandacek and Tso 2001). Organs such as liver, brain and skin can develop diseases in fish, and at certain levels can also cause mortality in many fish species (Hammond 1972, Gore et al. 2002, Kruse and Scarnecchia 2002, Lundebye et al. 2004).

Various chemical properties affect the fate and storage of contaminants in aquatic organisms and higher level predators such as humans. Compounds with high $\mathrm{K}_{\mathrm{ow}}$ values and low solubility, such as PCBs, polynuclear aromatic hydrocarbons (PAHs), benzene and chlorinated compounds will accumulate faster and persist longer in tissues high in lipids. Conversely, low $\mathrm{K}_{\mathrm{ow}}$ compounds are not as readily concentrated into lipids and therefore lost or degraded faster than high $\mathrm{K}_{\mathrm{ow}}$ values (Miller and Wasik 1985). High $\mathrm{K}_{\mathrm{ow}}$ values (above 6 
and 7) were found to be bioaccumulated mostly through the diet, while low $\mathrm{K}_{\mathrm{ow}}$ compounds (below 4) were found to be accumulated from the water (McKim and Heath 1983).

Intermediate $\mathrm{K}_{\mathrm{ow}}$ values can be accumulated through both the water and the diet (Hellou et al. 1997).

Chemical contaminants are introduced into a fish by ingestion of contaminated substances or by uptake across the respiratory membrane (Broman et al. 1989). Lipophilic organic contaminants will be deposited in the fat tissue of fish. Therefore, the highest concentrations of lipophilic contaminants will be located in the tissue that has the highest amount of fat tissue. Lipophilic contaminants will therefore accumulate in the fatty tissues such as the belly flap, lateral line, subcutaneous and dorsal fat, dark muscle, gills, eye, brain and internal organs (EPA 1999). Concentrations were found to be highest in fatty tissue and internal organs followed by muscle and liver with blood containing least amount (Hellou et al. 2002).

Food is expected to affect bioaccumulation of contaminants in the different fish tissue (Clements et al. 1994, Jackson 1996, Gobas et al. 1999, Wang and Fisher 1999). Fish may accumulate organic contaminants more rapidly from crayfish than emergent aquatic insects and other invertebrates that are lower in the food chain. This suggests that crayfish are opportunistic feeders, feeding on other benthic invertebrates, aquatic insects, detritus and even dead organisms (Kay et al. 2005). Non polar organic contaminants have a high affinity for aquatic particles, when the particles are enriched in organic carbon (Karickhoff et al. 1979, Voice and Webber 1983, Baker et al. 1991, and Ko and Baker 2004). Mussels, conversely, filter feed and therefore accumulate lipophilic contaminants at an increased rate from algae and suspended solids and also can be accumulated in the mussels from the 
aqueous phase if water column concentrations are high. These chemicals can accumulate in the feces and pseudofeces of mussels and then accumulate in the amphipods who feed on feces (Gewurtz et al. 2000). Crayfish did not have significant accumulation of organic contaminants in the Gewurtz study, which indicates that crayfish uptake these contaminants differently than mussels and amphipods or they metabolize them more readily, causing reduction in the crayfish's contaminant body burden.

Due to its lipophilic nature, it has been suggested that an individual with more adipose tissue will have a greater concentration of contaminants such as PCBs. To test the fate of the chemicals when lipid mobilization occurs, birds and rats were fed organic contaminants and then starved (Pelletier et al. 2003). Contaminant concentration increased in the adipose tissue, liver, heart, brain, and muscle. In humans, during periods of weight loss (specifically fat), organochlorine contaminant (including PCBs) concentrations in the blood plasma increased by as much as $19 \%$. The contaminant concentration was correlated with body weight, fat mass, and body mass index, which suggests that contaminant concentrations are indirectly proportional to the fat concentration and that these compounds are released into the blood during lipid mobilization (Pelletier et al. 2003). In a similar study, Imbeault et al. (2001) reported that weight loss and associated increase in lipid metabolism, as determined by lipolysis in subcutaneous abdominal and femoral adipocytes, occurred in combination with a rise in concentrations of plasma organochlorines. This supports the suggestion that contaminant levels increase with the level of lipids that are lost or mobilized by energy consumption of the fat reserves.

Research has shown that organochlorine compounds will accumulate in tissues with higher levels of lipid storage (Reinert 1969) and non-polar contaminants such as PCBs can 
partition into lipid deposits from water (Hamelink et al. 1971). Stow et al. (1997) found that within a species, there were weak correlations between lipid levels and PCB concentrations. However, it was found in a study by Hellou et al. (2002) that in terms of organochlorine concentrations in fish tissue, there should be more organic contaminants in fatty tissue than in internal organs, and less organochlorines in the blood than either other tissue type. Hellou et al. (2002) also found fatty tissue had the most lipids, with 4-5 times higher concentrations than internal organs, which had more than 100 times more lipids than blood. With lipid levels being highest in fatty tissue, then organs, then blood, it would then be assumed that organochlorine levels would be highest in fatty tissue, and then internal organs, then blood, however, Hellou et al. (2002) found PCB concentrations in the were not the same ratios as the lipid levels in the tissues. Therefore lipid concentrations alone do not necessarily explain the differences in contaminant concentrations. The concentrations of lipids and organochlorines in the liver and muscle had the same ratios, which suggest that the physiological effects of lipids on organochlorine concentrations is highly complex and will be affected by lipid levels, but also can be influenced by many other factors (Stow 1995, Stow et al. 1997, Hellou et al. 2002).

Seventy five to ninety percent of PCBs entering an organism are absorbed through the gastrointestinal tract and stored in fatty tissue including the liver, skin, and in mother's milk (USEPA 1999). The PCBs are transferred through the placenta and through milk in mothers who consume contaminated fish (Mendola et al. 1997). Acute doses have caused death in animals, although no human deaths have been documented due to PCB exposure. Chronic exposures in animal studies include hepatic, gastrointestinal, hematological, dermal, endocrine, immunological, reproductive, and developmental problems (ATSDR 1999). One 
human study demonstrated that PCB exposure resulted in lower birth weight, smaller head circumference, and shorter gestational age (Fein et al. 1994). PCBs are listed as a probable human carcinogen by the USEPA. They have also been shown to produce liver cancer in rats (ATSDR 1998). Polychlorinated biphenyls and PCB-like substances have been shown to cause various health problems in both fish and mammalian species (Rolland 2000). PCBs have been known to cause both acute and chronic toxicity. They have been shown to harm the hepatic, gastrointestinal, hematological, endocrine, immune, neural and reproductive systems, and have been associated with harmful developmental effects, mutagenicity and carcinogenicity. The EPA classifies PCBs as group B2-probable human carcinogens (USEPA 1999).

The central concern of PCB toxicity is that these chemicals are known endocrinedisrupters and enzyme inducers, and can impair thyroid functions (Pelletier et al. 2002). Gore et al. (2002) showed that certain mixtures of PCBs caused strong estrogen affects, whereas other mixtures caused weak estrogen and strong antiestrogenic or androgenic effects. Polychlorinated biphenyls disrupt the endocrine system by affecting gonadotropinreleasing hormone $(\mathrm{GnRH})$

Fish accumulate organic contaminants in different tissues based on the chemical's ability to persist in nature, its lipophilicity or hydrophilicity and the chemicals $\mathrm{K}_{\text {ow }}$ value (Guiney et al. 1979). This tissue distribution of chemical contaminants can therefore be altered by reproductive status due to lipid reserves and the water or lipid solubility of the compound, causing the chemical concentration of individual tissues to fluctuate from season to season. Foster et al. (2000) found that PCB levels in the Susquehanna River varied by season and were mostly influenced by runoff, winter snowmelt and rain. The study found 
that PCB concentrations spiked in the March/April months right after winter and was theorized that the PCB spike was a direct result of the snow melt and rain water runoff that followed the winter months of January and February. This same study found that this trend was not repeated with agricultural organochlorine pesticides, which share a similar chemical structure, but are used in land applications during the spring and summer months, unlike PCBs which are spread evenly throughout the environment through spills and accidental release. The study found that the pesticides generally spiked in June or August and showed no increase in April. Williams et al. (1989) found that PCB concentrations on a wet weight basis were highest in spring (May) and fall (September) and lowest in summer (July). These differences were not significant when the data were normalized to fish length and disappeared altogether when they were normalized to lipid content. This indicates that length of the fish and lipid content of the tissue are the greatest determination of seasonal PCB variation than season. Season will affect the lipid content and PCB concentration is affected by the lipid, but size of the fish (ie time of exposure of the fish) will have the greatest affects on fish tissue PCB concentrations.

Many contaminants are lipophilic and are stored and accumulated in the fat tissue, thus, it is possible that the higher fat concentrations might either: (1) dilute the contaminant concentrations, or (2) increase the concentrations of the contaminant due to an increase in bioaccumulation. The theory is that differences in seasonal temperature has an effect on the metabolic rate, enzyme activity, and variations in body fat content (Kellogg and Bulkley 1976), which might affect the seasonal variations of organic contaminants in fish tissue. A fish's feeding habits also change as the seasons change due to the changes in water 
temperature and the concentration of contaminant that is entering the fish's system (Black and Pickering 1998).

Channel catfish (Ictalurus punctatus) were selected as a benthic species in this study due to the high concentrations of PCBs in our research (Chapter 1), the importance of catfish as a sport fish in West Virginia and the popularity of catfish as a food source. The channel catfish is also found in abundance in the Monongahela River system and is a popular game fish species in the Morgantown area and throughout the country. The common carp (Ciprinus carpio) were selected as a species in this study due to availability of carp in the Monongahela River and the ease of capture. Carp are not considered game or sport fish in West Virginia and are not important sources of food; therefore carp was used as a model benthic species. Carp are excellent bioassay fish because of their hardiness, distribution and rapid growth rate. They are considered a pest and invasive species due to their ability to reproduce and grow rapidly and even overtake fish populations in some aquatic systems. Carp were selected for this project based on the criteria of having similar feeding and spawning characteristics to channel catfish.

Channel catfish, widely distributed throughout the US and the world by human expansion, is one of the most commercially important fish species in the United States. In 1991 there was 390 million pounds of channel catfish produced in the US (Morris 1993). Channel catfish live in water quality with dissolved oxygen of at least $4 \mathrm{ppm}$, become stressed at $3 \mathrm{ppm}$, and die at 1-2 ppm and tolerate a pH of 6 to 9 (Morris 1993).

Channel catfish spawning normally occurs at $23.9^{\circ} \mathrm{C}\left(75-80^{\circ} \mathrm{F}\right)$ as early as late February or as late as August depending on the area of the country (Carlander 1969, Wellborn 1998). They spawn in secluded semi-dark areas where the male catfish will build 
cavities by selecting the nest site and fanning out as much sediment as possible then defending the area until the eggs are hatched and the fry leave the nest. The female is attracted to the nest where the eggs are laid in the cavity, after which the female leaves the nest and the male fertilizes and then guards the eggs. Spawning only takes place once a year in females and more than once in males where the female produces 3000 to 4000 eggs per gram of body weight (Wellborn 1998). Adult catfish feed on small fish such as bluegills, gizzard shad and herring and also feed on chronimid larva and other aquatic insects (Carlander 1969).

The common carp, a minnow in the family Cyprinidae, (Page and Burr 1991, Balon 1995) has attained global distribution from its original population assumed to be in the Danube River in Europe. They are a hardy fish, occurring at a temperature range of 3 to $35^{\circ} \mathrm{C}$ and can tolerate a variety water conditions with a $\mathrm{pH}$ range of 7.0-7.5 and even survive in slightly brackish water. They thrive in warm water and in eutrophic rivers with muddy bottoms, slow flowing or standing waters with sediment bottoms. They are primarily benthic feeders feeding on vegetation, algae, benthic organisms (such as amphipods, aquatic larval insects and gastropods), detritus and plankton. Carp are known to cause increase in turbidity due to the digging and rooting for vegetation in shallow systems and also cause a decrease in benthic invertebrates and desirable fish species from predation on eggs and larva. Carp optimally spawn from March to July in most aquatic systems, but have been known to spawn in the early fall and early winter (Carlander 1969). Carp spawn by the female spreading eggs on submerged vegetation (from 100,000 to 500,000 eggs per spawn) where the eggs remain until they are hatched within a week. Carp can spawn twice in a season and can release up to $80 \%$ of the eggs in the first spawning period (Carlander 1969). 


\section{Objective}

The objective of this study was to determine if PCB concentrations in two benthic feeders (channel catfish and carp) vary with season, tissue type and gender.

\section{Materials and Methods:}

\section{Sample collection}

Channel catfish and common carp were collected from the Monongahela River in the Point Marion pool located between Morgantown, WV and Point Marion, PA. Samples were collected at the headwaters of the pool as close to the Morgantown lock and dam as practical. Samples were collected at three different times during the year to study seasonal concentrations of PCBs in the selected tissues. All samples were obtained in 2005. Samples were collected in May, before spawning but after winter when feeding increased and activity increased for both species. A second collection was taken in the July following spawning for both species. The third sampling event occurred in November, after spawning and before the winter period. Samples were collected within the Point Marion pool, through the use of gill nets, electro-shocking, or hook and line. In the May sampling period, 8 channel catfish and 12 common carp were collected. In the July sampling period, there were 20 channel catfish and 8 common carp collected. In the November sampling period, six catfish and 11 carp were collected.

Fish tissue samples were collected in accordance with EPA's Guidance for Assessing Chemical Contaminants Data for Use in Fish Advisories (USEPA 1995). Each collection had one size-class collected. A size class is defined as the shortest fish not measuring less than $75 \%$ of the total length of the longest fish (USEPA 1995). The variation of the size class will be determined by a percentage of the smallest and largest fish collected. Fish were 
placed on ice and returned to the laboratory. Fish samples were immediately wrapped in aluminum foil, appropriately labeled, and frozen. Fish were frozen at $-20^{\circ} \mathrm{C}$ until analyzed for PCBs.

\section{Laboratory analysis}

Lipid analysis of each tissue was performed on the Accelerated Solvent Extractor (ASE) using Dionex application note 337, with identical instrument parameters as the PCB extractions described above. Samples were dried and weighed (10 gram sample) and mixed with diatomaceous earth and placed in the stainless steel extraction vial with only a cellulose filter and no alumina. The vial was capped and placed on the ASE, with corresponding IChem jars placed in the sample collection rack. The PCB extraction procedure was ran according to the Dionex application note 337 and the lipid hexane extraction was collected in I-Chem jars. The extract was then placed in a dry, tared porcelain dish and placed in a drying oven for 10 minutes. The dish was then reweighed to a constant weight and recorded. Total percent lipids for each sample tissue were calculated by dividing the dry weight of the sample after extraction by the dry weight of the sample before extraction, and multiplying by 100 to convert to percentages. Liver samples for both catfish and carp were combined into a composite sample due to insufficient sample size, for each season, and then analyzed for percent lipid.

Fish were processed for PCB analysis at the National Research Center for Coal and Energy's Analytical Laboratory of West Virginia University. To determine age of fish, fin rays were collected from each fish and labeled until age can be determined. Egg samples from gravid females were collected to determine reproductive status. Egg samples were labeled with season, date of collection and fish number and were frozen at $-20^{\circ} \mathrm{C}$. The liver 
and gonads were collected and appropriately labeled with date of collection, fish number, sex and tissue type. The fish were processed to collect the edible portion of the fish tissue (fillets). Fillets were removed according to standard methods (USEPA 1998). All collected tissues (fillets, livers and gonads) were then stored at $-20^{\circ} \mathrm{C}$ until the tissue was homogenized. Again, tissues were homogenized according to standard methods (USEPA 1998). After each tissue was homogenized, samples were placed in glass sample jars and labeled with the appropriate sample label. Sample labels consisted of a code to represent which fish was collected and what month. Tissues were labeled first with the month of collection, either M for May, J for July or $\mathrm{N}$ for November, then the species name was abbreviated CC for channel catfish and $\mathrm{CP}$ for carp and the fish number which was initiated by the first fish caught being labeled 1 to the last fish caught for each sample. Finally, the type of tissue was also indicated on the sample jars, (I-Chem $250 \mathrm{ml}$ jars, and Fisher Scientific, Pittsburgh, PA) such as fillet, liver or gonad.

The frozen samples were each labeled and then extracted via EPA method 3545, Accelerated Solvent Extraction of Organic samples. Fish tissue samples were extracted with a Dionex ASE Accelerated Solvent Extractor 200 (Dionex Corp., Sunnydale, CA) using the Dionex application note (Number 337). Samples were extracted in $33 \mathrm{ml}$ stainless steel vials and collected in $60 \mathrm{ml}$ I-Chem certified jars (Fisher Scientific, Pittsburgh, PA). Extraction was completed by weighing a clean, dry solids porcelain dish, recording the weight, then weighing a 10 gram portion of sample and recording the weight. The sample was then dried overnight in a $104^{\circ} \mathrm{C}$ drying oven. Samples were then taken out of the drying oven and cooled to a constant volume by placing in a desiccator and repeatedly weighing until weight stabilized. Dried weight of samples was then recorded and a percent dry matter was 
calculated on all samples. Samples were then combined with 10 grams of diatomaceous earth (Fisher Scientific, Pittsburgh, PA) and mixed and crushed thoroughly using a mortar and pestle. Each stainless steel extraction vial was prepared by placing a cellulose extraction disk (D28 filter, p/n 049458, Dionex Corp., Sunnydale, CA) in the vial, then placing 5 grams of activated (heated to $400^{\circ} \mathrm{C}$ for four hours) alumina (Fisher Scientific, Pittsburgh, PA) then placing another cellulose filter on top of the alumina. This step was added to remove the coextracted lipid faction of the sample. The sample vial was then filled with the diatomaceous earth and dried sample mixture and capped. The Accelerated Solvent Extractor was then loaded with the stainless steel sample vials, taking care to load them with the alumina on the bottom, and the $60 \mathrm{ml} \mathrm{I-Chem} \mathrm{jars} \mathrm{are} \mathrm{labeled} \mathrm{and} \mathrm{placed} \mathrm{in} \mathrm{the} \mathrm{corresponding} \mathrm{position} \mathrm{of} \mathrm{the}$ sample extraction vial. Samples were spiked with $0.5 \mathrm{ul}$ of surrogate standard Decachlorobiphenyl (Restek Inc. 200ug/L) at a concentration of $0.1 \mathrm{mg} / 1$ for all standards. Recoveries of the surrogate were determined after the samples were analyzed on the GC. The ASE was run with hexane as the solvent with the following extraction procedure: system pressure $10 \mathrm{MPa}(1500 \mathrm{psi})$ with an oven temperature of $125^{\circ} \mathrm{C}$ and an oven heat up time of 6 minutes with 2 static cycles each 5 minutes, a flush volume of $60 \%$ of extraction cell volume with a nitrogen purge of $1 \mathrm{MPa}(150 \mathrm{psi})$ for 60 seconds for a total extraction volume of $40 \mathrm{ml}$. The extraction was then concentrated to less than $1 \mathrm{ml}$ on a Zymark TurboVapII concentrator (Zymark Corp.,Hopkinton, MA) under an ultra pure nitrogen stream, with a pressure of $14 \mathrm{psi}$ and a bath temperature of $40^{\circ} \mathrm{C}$. Sample extracts were then brought up to $1 \mathrm{ml}$ in the Zymark concentration tubes and quantitatively transferred to a $2.0 \mathrm{ml}$ amber sample vial (Fisher Scientific). Sample extracts are then cleaned using EPA method 3665A, Sulfuric acid /Permanganate Cleanup (EPA 3665). In this procedure, $1 \mathrm{ml}$ of sample extract 
was transferred to $10 \mathrm{ml}$ glass vial (Pyrex ${ }^{\circledR}$ Tube with Teflon ${ }^{\circledR}$ ) and $5 \mathrm{ml}$ of sulfuric acid diluted 1 to 1 with deionized water, was added to the hexane extract. After the vial was allowed to sit and any exothermic reaction or gas evolution ceased, the sample is capped with a Teflon ${ }^{\circledR}$ lined screw cap and vortexed (with a noticeable vortex in vial) for 1 minute. The sample was then allowed to sit for one minute to allow the layers to separate (aqueous and Hexane solvent). If the hexane layer was found to be cloudy or highly colored, the sulfuric acid layer was removed and $5 \mathrm{ml}$ of 1:1 sulfuric acid was added to the sample and the procedure repeated until a clean, clear hexane layer was obtained. After obtaining a clean hexane layer, the hexane layer was removed and quantitatively transferred into a new clean $10 \mathrm{ml}$ Pyrex ${ }^{\circledR}$ vial. An additional $1 \mathrm{ml}$ of hexane was added to the sulfuric acid portion and capped and shaken to ensure quantitative transfer of all PCBs from the sulfuric acid solution. This second hexane layer was removed and combined with the original hexane layer. To this combined hexane fraction, $5 \mathrm{ml}$ of aqueous potassium permanganate solution (Potassium Permanganate $\left(\mathrm{KMnO}_{4}\right)$ Fisher Sci) percent w/v in DI water) was added. Again the vial was capped and vortexed for 1 minute with a noticeable vortex in the vial. The sample was then checked for color and cloudiness. If there was cloudiness or color in the sample, the aqueous portion was removed and an additional $5 \mathrm{ml}$ of aqueous potassium permanganate was added to the hexane extract and again vortexed for a minute and allowed to stand and separate. Again, if the hexane was cloudy, the procedure was repeated until the hexane appeared clear. After the hexane was found to be clear, the hexane layer was quantitatively transferred to a clean $10 \mathrm{ml}$ Pyrex® tube and an additional $1 \mathrm{ml}$ of hexane was added to the aqueous potassium permanganate layer and capped and shaken. The extract was then allowed to sit and separate into layers and the hexane layer was removed and added to the clean hexane 
extract. The sample was then concentrated on the Zymark TurboVapII, as described above, to $1 \mathrm{ml}$ of sample. If concentration less than $1 \mathrm{ml}$ occurred, additional hexane was added to bring sample volume to $1 \mathrm{ml}$ and the final $1 \mathrm{ml}$ of hexane sample was carefully and quantitatively transferred to a $2 \mathrm{ml}$ amber colored sample vial.

Samples were then analyzed for PCBs, using EPA method 8082 (Window Chem software, 1991-1996). The Aroclor method of analysis was used by identifying the type and amount of each Aroclor based on patterns of Aroclor samples from Aroclor 1016, 1221, $1232,1242,1248,1254$ and 1260 standards injected at a $1 \mathrm{mg} / 1$ concentration. PCBs were analyzed on a Varian CP-3800 GC (Varian Analytical, Chicago Ill) equipped with a Varian 8410 auto injector with 10 position rack, dual 1177 split/splitless injectors and dual $\mathrm{Ni}^{63}$ Electron Capture Detectors, ECDs (Model number 02-001972-00). Injectors were set at $250^{\circ} \mathrm{C}$ and a split ratio of 10 to 1 . The ECD detectors were set a temperature of $320^{\circ} \mathrm{C}$, with a range of 1, a time constant of fast, a cell current of N2std. The analytical columns were Phenomenex (Torrance ,CA) Zebron ${ }^{\circledR}$ ZB-5, 30 meter by $0.53 \mathrm{~mm}$ i.d. by $1 \mu \mathrm{m}$ film thickness, Ser \# 120296 with a temperature limits of $360^{\circ} \mathrm{C}$ isothermal and $370^{\circ} \mathrm{C}$ maximum (P/N 7HK-G002-17) and a Phenomenex (Torrance, CA) Zebron® ZB-35 as the confirmation column was a 30 meter by $0.53 \mathrm{~mm}$ i.d. by $0.5 \mu \mathrm{m}$ film thickness, Ser \# 108727 with a temperature limits of $340^{\circ} \mathrm{C}$ isothermal and $360^{\circ} \mathrm{C}$ maximum (P/N 7HG-G003-17). Column flow was controlled by Type 13 electronic flow controllers at a column flow of $5 \mathrm{ml} / \mathrm{min}$ through the columns and a makeup flow of $25 \mathrm{ml} / \mathrm{min}$ through the detectors. Carrier and makeup gas was ultra high purity nitrogen from Mountaineer Airgas (Morgantown, WV). The injectors were kept at a constant temperature of $250^{\circ} \mathrm{C}$ during the injection process. The column oven temperature program was an initial temperature of $150^{\circ} \mathrm{C}$, held for 0.5 minutes, 
then a ramp of $12^{\circ} \mathrm{C}$ to $190^{\circ} \mathrm{C}$ and held for 4 minutes, then a final ramp of $4^{\circ} \mathrm{C} / \mathrm{min}$ to a final temperature of $275^{\circ} \mathrm{C}$ and a hold of 10 minutes to make the total analysis time of 39.08 minutes. Data analysis was performed on the GC software Star Chromatography version 6.20 .

\section{Statistical Analysis}

Data for concentrations of PCBs were examined by one-way analysis of variance (SAS 1989). The General Linear Model procedure was performed for seasonal comparison due to uneven sample sizes. For all statistical tests, significance level was set at $P<0.05$. Comparisons at the $P<0.1$ level were further examined by multiple means comparison. Effects of parameters, other than season, were eliminated by performing a least squares fit model on age, sex, length, and weight. Least squares fit model was performed using JMP software (JMP 2007) and tested against $P<0.05$.

\section{Results}

PCB data was tested on both percent moisture basis and a lipid normalized basis. PCB concentration was plotted against percent lipid of the tissue using linear regression to test if a linear relationship existed between the percent lipid of each tissue and the PCB concentration in $\mathrm{mg} / \mathrm{kg}$. If a linear relationship exists between these two variables, then it is appropriate to report the data on a lipid normalized basis, however, if no linear relationship exists, then it is appropriate to report the data on a percent moisture basis (Hebert and Keenleyside 1995).

For channel catfish and carp, linear regression was performed to examine the relationship between PCB concentration and lipid content of fillet; no relationship was found (channel catfish $r^{2}=0.0541$, carp $\left.r^{2}=0.0875\right)$. 
For channel catfish liver, a linear relationship did not exist at an r-squared value of 0.0956. However, liver samples for both channel catfish and carp were tested for lipid content by compositing the sample from each season into a single homogenized fraction and testing the composite for lipid content. This was performed because of the insufficient sample size to analyze both fish PCBs and lipids on the same tissue. Carp lipids also were not linearly correlated and with an r-squared value of 0.1500 , and therefore should be reported on a percent moisture basis and not lipid normalized PCB data. Carp gonads and channel catfish gonads were not linearly correlated at an r- squared value of 0.0153 for carp gonads and an r-squared value of 0.0 for channel catfish.

May channel catfish had a mean length of $448.9 \pm 15.3 \mathrm{~mm}$ and a mean weight of $941.8 \pm 106.1$ grams. Of the 8 channel catfish caught in May, six were males and two were females, with one female found to be gravid. July channel catfish had a mean length of 479.6 $\pm 13.8 \mathrm{~mm}$ and an average weight of $1049.7 \pm 143.9$ grams. Of the 13 channel catfish caught in July seven were males and five were females, with no females found to be gravid. November channel catfish had a mean length of $555.6 \pm 18.46 \mathrm{~mm}$ and a mean weight of $1723.6 \pm 317.6$ grams. Of the 6 channel catfish caught in November one was male and five were females, with one female found to be gravid.

Mean PCB concentrations for May catfish fillets were $0.41 \pm 0.10 \mathrm{mg} / \mathrm{kg}$ with all Aroclors being 1260 (Figure 1). Average PCB concentrations for July catfish fillets were $0.28 \pm 0.06 \mathrm{mg} / \mathrm{kg}$ (Figure 1), with PCBs found in every sample but two and all Aroclors were 1260. Mean PCB concentrations for November catfish fillets were $0.14 \pm 0.06 \mathrm{mg} / \mathrm{kg}$ (Figure 1) with PCBs found in every sample, but one and all Aroclors were 1260. 
For May channel catfish livers, four samples were found to have detectable PCB concentrations and four having no detectable PCB concentrations with a mean of $0.08 \pm 0.04$ $\mathrm{mg} / \mathrm{kg}$ with all Aroclors being 1260 (Figure 2). For July livers, all samples but two were found to have detectable PCB concentrations with an average of $0.14 \pm 0.04 \mathrm{mg} / \mathrm{kg}$ (Figure 2) with all Aroclors being 1260. For November livers, all samples but one was found to have detectable PCB concentrations with an average of $0.25 \pm 0.09 \mathrm{mg} / \mathrm{kg}$ (Figure 2) with all Aroclors being 1260 .

Mean PCB concentrations in May channel catfish gonad samples were found in three gonads at a mean concentration of $0.44 \pm 0.22 \mathrm{mg} / \mathrm{kg}$ (Figure 3 ) with only one 1254 Aroclor found, and the others contain Aroclor 1260. PCBs were found in eight gonads for July at a mean concentration of $0.52 \pm 0.31 \mathrm{mg} / \mathrm{kg}$ (Figure 3) with all Aroclors being 1260. For November, PCBs were found in four gonads at a mean concentration of $0.21 \pm 0.12$ (Figure 3) $\mathrm{mg} / \mathrm{kg}$ with all Aroclors being 1260 .

May carp had a mean length of $549.4 \pm 12.2 \mathrm{~mm}$ and an average weight of $2423.4 \pm$ 162.1 grams. Of the 10 carp caught in May, eight were males and two were females, both found to be gravid. July carp had a mean length of $549.4 \pm 12.0 \mathrm{~mm}$ and a mean weight of $2212.6 \pm 198.6$ grams, and of the 8 carp collected in July, 4 were males and 4 were gravid females. November carp had a mean length of $541.5 \pm 9.8 \mathrm{~mm}$ and a mean weight of 2590.2 \pm 139.5 grams. Of the 11 carp caught in November, nine were males and two were females, with both females being gravid.

Mean PCB concentrations for May carp fillets were $0.28 \pm 0.04 \mathrm{mg} / \mathrm{kg}$ (Figure 4) with PCBs found in every sample and all Aroclors were 1260. Mean PCB concentrations for July carp fillets were $0.13 \pm 0.07 \mathrm{mg} / \mathrm{kg}$ (Figure 4) with PCBs found in every sample but 
three and Aroclor 1248, 1254 and 1260 were all found. Mean PCB concentrations for November carp fillets were $0.18 \pm 0.05 \mathrm{mg} / \mathrm{kg}$ (Figure 4) with PCBs found in every sample as Aroclor 1260.

For May carp livers, no samples were found to contain detectable PCB concentrations (Figure 5). For July livers, three samples were found to contain detectable PCB concentrations with an average of $0.05 \pm 0.03 \mathrm{mg} / \mathrm{kg}$ (Figure 5) with all Aroclors being 1260. For November livers, three samples were found to contain no detectable PCB concentrations. PCBs were found in the eight November livers at a mean concentration of $0.10 \pm 0.04 \mathrm{mg} / \mathrm{kg}$ (Figure 5) with all Aroclors being 1260.

For May carp, PCBs were found in five gonads at an average concentration of $0.13 \pm$ $0.05 \mathrm{mg} / \mathrm{kg}$ (Figure 6) with all samples containing Aroclor 1260. PCBs were found in all but two gonads for July at a mean concentration of $0.20 \pm 0.05 \mathrm{mg} / \mathrm{kg}$ (Figure 6) with all Aroclors 1260. PCBs were found in all but four gonads at a mean concentration of $0.09 \pm$ $0.03 \mathrm{mg} / \mathrm{kg}$ (Figure 6) with all Aroclors 1260.

\section{Seasonal Differences}

Seasonal variations of PCB concentrations were significant in channel catfish fillets $(P<0.1)$ when tested against multiple comparison test which found seasonal affects were significantly different for May and November $(P=0.017)$, but not May and July or November and July (Figure1). The channel catfish gonads were not significant, and catfish livers were not significantly different for any season.

Carp fillets and gonads were not significantly different for any season. Carp livers were significant $(\mathrm{P}<0.05)$ when tested against the multiple comparison test which found 
seasonal differences between May and November $(P=0.018)$, but not May and July or July and November (Figure 5).

\section{Gender Differences}

PCB concentrations were tested between males and females for each species and each season (Figure 7, 8, 9). May male channel catfish fillets contained $0.48 \pm 0.11 \mathrm{mg} / \mathrm{kg}$ PCBs and females had concentrations of $0.17 \pm 0.17 \mathrm{mg} / \mathrm{kg}$ PCBs and were not significantly different. July male channel catfish fillets contained $0.41 \pm 0.073 \mathrm{mg} / \mathrm{kg}$ PCBs and females had concentrations of $0.25 \pm 0.093 \mathrm{mg} / \mathrm{kg}$ PCBs and were not significantly different. November male channel catfish fillets contained $0.098 \pm 0 \mathrm{mg} / \mathrm{kg}$ PCBs and females had concentrations of $0.11 \pm 0.081 \mathrm{mg} / \mathrm{kg}$ PCBs and were not significantly different (Figure 7). May male carp fillets contained $0.30 \pm 0.049 \mathrm{mg} / \mathrm{kg}$ PCBs and females had concentrations of $0.21 \pm 0.073 \mathrm{mg} / \mathrm{kg}$ PCBs and were not significantly different. July male carp fillets contained $0.12 \pm 0.096 \mathrm{mg} / \mathrm{kg}$ PCBs and females had concentrations of $0.13 \pm 0.10 \mathrm{mg} / \mathrm{kg}$ PCBs and were not significantly different. November male channel catfish fillets contained $0.19 \pm 0.066 \mathrm{mg} / \mathrm{kg}$ PCBs and females had concentrations of $0.16 \pm 0.05 \mathrm{mg} / \mathrm{kg}$ PCBs and were not significantly different (Figure 7).

May channel male catfish livers contained $0.070 \pm 0.042 \mathrm{mg} / \mathrm{kg}$ PCBs and females had concentrations of $0.11 \pm 0.1 \mathrm{mg} / \mathrm{kg}$ PCBs and male PCB concentrations were not significantly different than female PCB concentrations. July male channel catfish livers contained $0.15 \pm 0.070 \mathrm{mg} / \mathrm{kg}$ PCBs and females had concentrations of $0.13 \pm 0.049 \mathrm{mg} / \mathrm{kg}$ PCBs and were not significantly different. November male channel catfish livers contained 0 $\pm 0 \mathrm{mg} / \mathrm{kg}$ PCBs and females had concentrations of $0.34 \pm 0.095 \mathrm{mg} / \mathrm{kg}$ PCBs and were not significantly different (Figure 8). May male carp livers contained $0.001 \pm 0.00099 \mathrm{mg} / \mathrm{kg}$ 
PCBs and females had concentrations of $0 \pm 0 \mathrm{mg} / \mathrm{kg}$ PCBs and were not significantly different. July male carp livers contained $0.04 \pm 0.042 \mathrm{mg} / \mathrm{kg}$ PCBs and females had concentrations of $0.06 \pm 0.03 \mathrm{mg} / \mathrm{kg}$ PCBs and were not significantly different. November male carp livers contained $0.080 \pm 0.044 \mathrm{mg} / \mathrm{kg}$ PCBs and females had concentrations of $0.16 \pm 0.030 \mathrm{mg} / \mathrm{kg}$ PCBs and were not significantly different (Figure 8).

May channel male catfish gonads contained $0.56 \pm 0.27 \mathrm{mg} / \mathrm{kg}$ PCBs and females had concentrations of $0.049 \pm 0.049 \mathrm{mg} / \mathrm{kg}$ PCBs and were not significantly different. July male channel catfish gonads contained $0.64 \pm 0.52 \mathrm{mg} / \mathrm{kg}$ PCBs and females had concentrations of $0.42 \pm 0.39 \mathrm{mg} / \mathrm{kg}$ PCBs and were not significantly different. November male channel catfish gonads contained $0 \pm 0 \mathrm{mg} / \mathrm{kg}$ PCBs and females had concentrations of $0.29 \pm 0.18$ $\mathrm{mg} / \mathrm{kg}$ PCBs and were not significantly different (Figure 9).

May male carp gonads contained $0.14 \pm 0.55 \mathrm{mg} / \mathrm{kg}$ PCBs and females had concentrations of $0.11 \pm 0.11 \mathrm{mg} / \mathrm{kg}$ PCBs and were not significantly different. July male carp gonads contained $0.19 \pm 0.073 \mathrm{mg} / \mathrm{kg}$ PCBs and females had concentrations of $0.20 \pm$ $0.091 \mathrm{mg} / \mathrm{kg}$ PCBs and were not significantly different. November male carp gonads contained $0.082 \pm 0.03 \mathrm{mg} / \mathrm{kg}$ PCBs and females had concentrations of $0.11 \pm 0.11 \mathrm{mg} / \mathrm{kg}$ PCBs and were not significantly different (Figure 9).

In channel catfish fillets, gonads and liver, PCBs were not significant at $P<0.05$ for length, age, weight and sex. In common carp, fillets, gonads and livers for PCBs were not significant at $P<0.05$ for length, age, weight and sex.

\section{Discussion}

Previous studies have reported PCB concentrations in an aquatic environment on either a lipid normalized basis (Ruiz and Llorente 1991) or a percent moisture basis 
(Williams et al. 1989). However, it may not always be appropriate to lipid normalize contaminants in fish tissue. First it must be assumed that lipids are distributed evenly from tissue to tissue and from fish to fish. It must also be assumed that the lipid content is correctly and accurately analyzed, even though no certification or standard laboratory procedure exists for lipid analysis and error can occur without regulation. Lipid normalized ratios only correct for the lipid when the relationship between the two variables is isometric; therefore, all species and tissues were tested to determine if PCB data and percent lipid were linear. If the PCB data was found to be linear, data reported on a lipid normalized basis will be appropriate, but if not linear, then data should be reported on a percent moisture basis (Hebert and Keenleyside 1995). For channel catfish tissues, a linear regression was performed against percent lipid content of the tissue and PCB concentration in $\mathrm{mg} / \mathrm{kg}$. It was found for channel catfish tissues and carp tissues that a linear relationship does not exist and therefore PCB values in this study are reported as percent moisture and not percent lipid.

\section{Differences due to Gender}

There were no significant differences between males and females within a given season for any tissue or either species. Our study contradicts previous studies that found channel catfish had different concentrations of PCBs between male and female in a contaminated lake (Rypel et al. 2007). However, Rypel explained the differences were due to the location of the point source pollution at the time of spawning, when the females traveled up the creek to spawn near a known source of PCB contamination. The Rypel et al. study (2007) also tested several other species for gender PCB concentrations, and found male and female channel catfish, largemouth bass (Micropterus salmoides), and spotted bass (Micropterus punctulatus) tissues contained different levels of PCBs, but striped bass 
(Morone saxatilis), black crappie (Pomoxis nigromaculatus) and freshwater drum (Aplodinotus grunniens) did not show any differences.

A study conducted by Johnston et al. (2002) found for some populations of walleye, there were gender variations, but other populations showed no differences. The Johnston et al. study (2002) indicates that although several different populations show gender differences in PCB concentrations, gender differences of PCBs in tissue were not evident in all populations indicating that sex alone is not the deciding factor in PCB accumulation. Ecosystem variation seems to be a major contributor to gender differences as explored by Zlokovitz and Secor (1999). They found that striped bass had gender differences in one ecosystem population, but not in another, of which both ecosystems were lakes, revealing that point source pollution of PCBs are major contributors to contaminant variations.

Gender differences of PCBs in fish tissue are not evident in all species. It is interesting to note that channel catfish (benthic feeder) had gender differences in the Rypel et al. (2007) study along with two other species considered predators but freshwater drum and two mixed diet species displayed no gender differences. The Johnston et al. (2002) study, which contained only a predator species, found gender differences in some locations but not in other locations, and found that the size of the fish had an effect on the magnitude of the gender differences of PCB concentrations. These studies, along with the current study, only

confirm that the bioaccumulation of PCBs within fish tissue are affected by multiple complex variables and will differ greatly from location to location and species to species, along with size, age and contamination inputs.

\section{Seasonal Differences}


Seasonal differences of contaminants in aquatic systems have been studied for some time. As early as the 1970s, researchers were looking at seasonal effects of organic and inorganic contaminants in fish tissue and waterways (Olsson et al. 1978). There are many studies that have looked at seasonal variations of contaminants in fish tissue (Kellogg and Bulkley 1976, Williams et al. 1989, Ruiz and Llorente 1991, Foster et al. 2000, Greenfield et al. 2005), air (Bamford et al. 2002), water (Kellogg and Bulkley 1976, Foster et al. 2000, Söderström et al. 2000, Mzimela et al. 2003, Ko and Baker 2004), sediments (Mzimela et al. 2003) and the aquatic food chain (Kunisue et al. 2002). The implications for seasonal variations can have impacts on consumption of fish tissue, fish health and reproduction.

There were no significant effects for size, age, weight or sex, which would indicate that the selective sampling procedure used to eliminate all variables except the seasonal effect on PCB differences proved successful, indicating that statistically, all seasonal variations in PCB concentrations comes from the seasonal parameter alone.

Williams et al. (1989) looked at seasonal variations of PCBs in Chinook salmon (Oncorhynchus tshawytscha) in Lake Michigan. This study looked at a salmonid species, in a lake environment. The PCB levels for salmon are an important factor considering human consumption of salmon and the economic impact of the salmon fishery. A literature search revealed no studies on seasonal concentrations of PCBs in channel catfish. Seasonal studies have been conducted on all types of aquatic and terrestrial taxa, including carp (Ruiz and Llorente 1991), eel (Anguilla anguilla) (Ruiz and Llorente 1991), salmon (Williams et al. 1989) Atlantic herring (Clupea harengus) mackerel (Scomber scombrus), white hake (Urophycis tenuis), capelin (Mallotus uillosus), gaspereau (Alosa pseudoharengus) and smelt (Osmerus mordax) (Harding et al. 1997) and birds (Kunisue et al. 2002). 
PCBs are lipophilic and have been shown to be proportional to lipid content (Reinert 1969). However, our study found no positive correlation between the tissue lipid content and the PCB concentration of the tissue. Our study shows that PCB concentrations are not directly proportional or connected to the lipid content of the tissue. As discussed in Stow et al. (1997) the lipid content:PCB concentration correlation between individual fish populations were not evident. When compared to the means of different species, there was a correlation, indicating that the higher the lipid content in a fish, the higher the PCB content, which may be the case for our study, if more species were tested. However, like the Stow et al. study, our study found no correlations between the tissue lipid content and the PCB concentrations, indicating that lipid content had no direct effect on PCB concentrations. As discussed earlier, this may be due to the dilution of PCBs by higher lipid content in the tissues.

Our results were comparable to Williams et al. 1989 in finding differences within season. As mentioned before, their study examined salmon instead of channel catfish or carp; however, their study did look at similar seasons to our study. The three seasons represented were May, July and September. The Williams study found significant differences of PCB concentrations in the salmon fillets (percent moisture basis), where May and July were significantly different $(1.07 \mathrm{mg} / \mathrm{kg}$ and $0.81 \mathrm{mg} / \mathrm{kg})$, but not different from the September sampling period, compared to our results which showed significant differences between May and November for catfish fillets, but did not have differences between the May sampling period and the July sampling period or the November sampling period and the July sampling period. The Williams et al. study found that there were no differences from May to September or July to September, which is the opposite of our study. Also, our study did not 
show any differences from season for the carp fillets. As outlined in Olsson et al. (1978), spring spikes of PCB concentrations in roach (Rutilus rutilus) was common over a seven year period, occurring around May, leading to the conclusion that PCB monitoring should be completed at times of steady PCB concentrations and not at peaks when physical impacts such as snow fall, sediment, runoff or physiological peaks such as spawning, migration or winter lipid deposition. As previously discussed, snow and rainfall can have an effect on PCB concentrations within a water body, spiking PCB concentrations noticeably whenever there is a rain event or other runoff event that affects the flow of water into the water system (Foster et al. 2000). This seems to be the case for channel catfish fillets in our study, where the spring sampling period contained the highest concentrations of PCBs. Carp fillets also had higher mean concentrations of fillets in the spring although not significantly different. Rainfall concentration fluctuations may or may not have had an immediate effect on the tissue concentrations of PCBs in the fish. Immediate flow increase can mix water with sediment that has formed a sink for contaminants, and cause a spike in the water concentrations of PCBs along with actually increasing the PCB load to the water due to washing contaminants into the waterway from sources on land. This could explain the higher concentrations of PCBs in the channel catfish fillets in the May sampling period, versus the later sampling periods of July and November. All of these sources and containments must be taken into account when studying seasonal and tissue distribution effects in fish.

The seasonal differences of fillets, noted in our study were significant, but like the Williams et al. study, were not strongly significant and did not show strong correlation. Also, the fillets analyzed in the Williams et al. study were trimmed for fat before being analyzed which could explain the differences that were observed between the two studies, not 
only in the seasonal trend, but also the concentrations of PCBs. Previous studies have found the highest concentrations of organochlorine contaminants to be in the fattier portions of the fish (Reinert 1969). Although our study did not find a direct correlation between the lipid content of the tissues and the PCB concentrations of the tissue, lipid concentrations still affect PCB concentrations, as evidenced by our study and other similar studies (Harding et al. 1997, Stow et al. 1997, Ruiz and Llorente 1991).

Similar to our study, seasonal differences in tissue PCB concentration have been examined in carp and eel. Ruiz and Llorente (1991) study sampled carp and eel every month of the year except for March and October. This makes comparison of results to our study difficult since only three seasons were examined in our study. However, it does give a better picture of how the PCB concentration fluctuates over a period of the entire calendar year. PCB concentrations for carp were highest in April and May with a substantial dip in June, and July, with another peak in August and a corresponding drop in November and December. The authors suggested that the differences in seasonal PCB concentrations were due to the opening of the rice channels in April. These findings compare to our study in that the highest level of PCBs recorded were in May, during the rainy season, which would cause the sediment of the Monongahela River to stir and PCBs buried in the sediment would then be available for fish uptake. Harding et al. (1997) also found a spike in the spring time around June for fish sampled and also in plankton. This later spike (June) is due to the later spring season experienced by the study area (Nova Scotia) but coincides well with the Ruiz and Llorente (1991) study and also our study in PCB concentration spikes occurring in the spring when rain and snow melt occur. 
The importance of our study was the channel catfish fillets, which showed significant differences in seasonal sampling periods. It is useful to know if there is seasonal variation in livers and gonads of channel catfish for research purposes but these conclusions have no practical value in human health. Channel catfish are considered a sport fish in West Virginia and our study gives practical implications as to when catfish populations have the lowest concentrations of contaminant levels.

\section{Conclusion}

Most tissues did not show seasonal differences of PCB concentrations with the exception of channel catfish fillets which contained significant differences from May to November. Due to the complex interactions associated with PCB uptake, distribution, elimination and degradation, it is difficult to prove whether seasonal effects are present and what the sources of the differences are.

Although production of PCBs was previously banned, these chemicals are present in the environment today. The persistence of these chemicals in the environment is due to their chemical properties. The bioaccumulation of these chemicals in fish tissue not only produce a health concern for humans who ingest the fish, but are also threaten the health and well being of the fish population. To reduce or remove these chemicals from the environment, additional research must be conducted to explore the possibilities of hydrolyzing the contaminants in the fish or biodegrading the contaminants in the environment prior to entering the fish. Until new technologies for removal of PCBs from the environment are developed, PCB contamination entering the environment must be reduced. 


\section{References:}

Agency for Toxic Substances and Disease Registry. 1999. Mercury CAS \# 7439-976. ATSDR ToxFAQs.

Baker JE, Eisenreich SJ, Eadie BJ. 1991. Sediment trap fluxes and benthic recycling of organic carbon, polycylic aromatic hydrocarbons, and polychlorinated biphenyl congeners in Lake Superior. Environmental Science Technology. 25(3): 500-509.

Balon EK. 1995. Origin and domestication of the wild carp, Cyprinus Carpio: from Roman gourmets to the swimming flowers. Aquaculture 129: 3-48.

Bamford HA, Ko FC and Baker JE. 2002. Seasonal and annual air-water exchange of polychlorinated biphenyls across Baltimore Harbor and the northern Cheasapeake Bay. Environmental Science Technology. 36:4245-4252.

Black KD and Pickering AD. 1998. Biology of Farmed Fishes. Sheffield Academic Press LTD. Sheffield, England.

Borga K, Gabrielsen GW, Skaare JU. 2001. Biomagnification of organochlorines along a Barents Sea food chain. Environmental Pollution. 113: 187-198.

Broman D, Näf C, Zebühr Y, Lexén K. 1989. The composition, distribution and flux of PCDDs and PCDFs in settling particulate matter (SPM) - a sediment trap study in the northern Baltic - Chemosphere. 19: 445-450.

Carlander KD. 1969. Handbook of Freshwater Fishery Biology. Life history data on freshwater fishes of the United States and Canada, exclusive of the Perciformes. I: 369390, 538-554.

Clements WH, Oris JT, Wissing TE. 1994. Accumulation and food chain transfer of luoranthene and benzo[a]pyrene in Chironomus riparius and Lepomis macrochirus. Archives of Environmental Contamination and Toxicology. 26: 261-266.

Eisler R. 1986. Polychlorinated biphenyl hazards to fish, wildlife, and invertebrates: A synoptic review. US Fish and Wildlife Service Biological Report, 1986. pwrc.usgs.gov

Fein GG, Jacobson JL, Jacobson SW, Schwartz PM, Dowler JK. 1984. Prenatal exposure to polychlorinated biphenyls: effects on birth size and gestational age. Journal of Pediatrics 105: 315-320.

Foster GD, Lippa KA, Miller CV. 2000. Seasonal concentrations of organic contaminants at the fall line of the Susquehanna River Basin and estimated fluxes to northern Cheaspeake Bay. USA. Environmental Toxicological Chemistry. 19: 992-1001. 
Froese KL, Verbrugge DA, Ankley GT, Neimi GJ, Larsen CP, Giesey JP. 1998. Bioaccumulation of polychlorinated biphenyls from sediments to aquatic insects and tree swallow eggs and nestlings in Saginaw Bay, Michigan, USA. Environmental Toxicological Chemistry. 17: 484-492.

Gewurtz SB, Lazar R, Haffner GD. 2000. Comparison of polycyclic aromatic hydrocarbon and poly chlorinated biphenyl dynamics in benthic invertebrates of Lake Erie, USA. Environmental Toxicological Chemistry. 19: 2943-2950.

Giesy JP, Kurunthachalam K. 1998. Dioxin-like and non-dioxin like effects of polychlorinated biphenyls: Implications for risk assessment. Lakes \& Reservoirs: Research and Management 2002; 7:139-181.

Gore A, Wu J, Oung T, Lee J, Woller M. 2002. A novel mechanism for endocrinedisrupting effects of polychlorinated biphenyls: direct effects on gonadotropinreleasing hormone neurons. Journal of Neuroendocrinology. 14: 814-823.

Gobas FAPC, Wilcockson JB, Russell RW, Haffner GD. 1999. Mechanism of biomagnification in fish under laboratory and field conditions. Environmental Science Technology. 33: 133-141.

Grandjean P, Weihe P, Needham LL, Burse VW, Patterson DG Jr., Sampson, EF, Jorgensen PJ, Vahter M. 1995. Relation of a Seafood diet to Mercury, Selenium, Arsenic, and Polychlorinated Biphenyl and other organchlorine concentrations in human milk. Environmental Research. 71: 29-38.

Greenfield BK, Davis JA, Fairey R, Roberts C, Crane D, Ichikawa G. 2005. Seasonal, interannual, and long-term variation in sport fish contamination, San Francisco Bay. Science of the Total Environment. 336(1-3): 25-43.

Guiney PD, Melancon MJ, Lech JJ, Peterson RE. 1979. Effects of egg and sperm maturation and spawning on the distribution and elimination of a polychlorinated biphenyl in rainbow trout (Salmo gairdneri). Toxicology and Applied Pharmacology. 47: 261-272.

Harding GC, Leblanc RJ, Vass WP, Addison Rf, Hargrave BT, Pearre S, Dupuis A, Brodie P. 1997. Bioaccumulation of polychlorinated biphenyls (PCBs) in the marine pelagic food web, based on seasonal study in the southern Gulf of St. Lawrence. Marine Chemistry. 56: 145-179.

Hamelink JL, Waybrant RC, Ball RC. 1971. A proposal: exchange equilibria control the degree chlorinated hydrocarbons are biologically magnified in lentic environments. Trans American Fishery Society. 100: 207-214.

Hammond AL. 1972. Chemical pollution: polychlorinated biphenyls. Science. 175 (4017): 155-156. 
Hawker DW, Connell DW. 1988. Octanol-water partition coefficients of polychlorinated biphenyl congeners. Environmental Science Technology 22: 382-387.

Hebert HE, Keenleyside KA. 1995. To normalize or not to normalize? Fat is the question. Environmental Toxicology and Chemistry. 14(5): 801-807.

Hellou J, Leonard J, Anstey C. 2002. Dietary exposure to aromatic contaminants and tissue distribution. Archives of Environmental Contaimination and Toxicology. 42(4): $470-476$.

Hellou J, Mackay D, Fowler B. 1997. Bioconcnetration of PAC from sediments to muscle in finfish. Environmental Science Technology. 29: 2555-2560.

Hill WR, Napolitano GE. 1997. PCB Congener Accumulation by Periphyton, Herbivores, and Omnivores. Archives of Environmental Contaimination and Toxicology. 32: 449-455.

Imbeault P, Chevrier J, Dewailly E, Ayotte P, Despres J, Tremblay A, Mauriege P. 2001. Increase in plasma pollutant levels in response to weight loss in humans is related to in vitro subcutaneous adipocyte basal liolysis. International Journal Obesity. 25: 1-7.

Jackson JJ. 1996. Contrast of constant and bioenergetics-based assimilation efficiency in describing ecosystems. Ecological Applications. 6: 1355-1364.

Jandacek RJ, Tso P. 2001. Factors affecting the storage and excretion of toxic lipophilic Xenobiotics. Lipids. 36(12): 1289-1305.

Johnston TA, Fisk AT, Whittle DM and Muir DCG. 2002. Variation in organochlorine bioaccumulation by a predatory fish; gender, geography and data analysis methods. Environmental Science and Technology. 36: 4238-4244.

JMP, Version 7. 2007. SAS Institute Inc., Cary, NC.

Karickhoff SW, Bromn DS, Scott TA. 1979. Sorption of hydrophobic pollutants on natural sediments. Water Research. 13: 241-248.

Kay DP, Blankenship AL, Coady KK, Neigh AM, Zwiernik MJ, Millsap SD, Strause K, Park C, Bradley P, Newsted JL, Jones PD, Giesy JP. 2005. Differential accumulation of polychlorinated biphenyl congeners in the aquatic food web at the Kalamazoo River Superfund Site, Michigan. Environmental Science Technology. 39: 5964-5974.

Kellogg RL, Bulkley RV. 1976. Seasonal concentrations of dieldrin in water, channel catfish and catfish-food organisms, Des Moines River, Iowa. 1971-73. Pesticide Monitoring Journal. 39: 186-194. 
Ko FC, Baker JE. 2004. Seasonal and annual loads of hydrophobic organic contaminants from the Susquehanna River basin to the Chesapeake Bay. Marine Pollution Bulletin: 48: $840-851$.

Kruse G, Scarnecchia D. 2002. Assessment of bioaccumulated metal and organochlorine compounds in relation to physiological biomarkers in Kootenai River white sturgeon. Journal of Applied Ichthyology. 18: 430-438.

Kunisue T, Binh Minh T, Fukuda K, Watanabe M, Tanabe S, Titenko AM. 2002. Seasonal Variation of Persistent Organochlorine Accumulation in Birds from Lake Baikal, Russia, and the Role of the South Asian Region as a Source of Pollution for Wintering Migrants. Environmental Science Technology. 36: 1396-1404.

Lundebye AK, Berntssen MHG, Lie O, Ritchie G, Isosaari P, Kiviranta H, Vartiainen T. 2004. Dietary uptake of dioxins (PCDD/PCDFs) and dioxin-like PCBs in Atlantic salmon (Salmo salar). Aquaculture Nutrition. 10: 199-207.

Mendola P, Buck GM, Sever LE, Zielenzy M, Vena JE. 1997. Consumption of PCBcontaminated freshwater fish and shortened menstrual cycle length. American Journal Epidemiology. 146: 955-960.

McKim JM, Heath EM. 1983. Dose determinations for waterborne 2,5,2',5'-

$\left[{ }^{14} \mathrm{C}\right]$ tetrachlorobiphenyl and related pharmacokinetics in two species of trout (Salmo gairdneri and Salvelinus fontinalis): A mass-balance approach. Toxicology and Applied Pharmacology 68 (2): 177-187.

Miller M, Wasik L. 1985. Relationships between octanol-water partition coefficientand aqueous solubility. Environmental Science Technology. 19(6): 522-529.

Morris JE. 1993. Pond Culture of Channel Catfish in the North Central Region. NCRAC publication FS 106.

Mzimela HM, Wepener V, Cyrus DP. 2003. seasonal variation of selected metals in sediments, water and tissues of the groovy mullet, Liza dumerelii (Mugilidae) form Mhlathuze Estuary, South Africa. Marine Pollution Bulletin. 46: 659-676.

Olsson M, Jensen S, Reutergard L. 1978. Seasonal variation of PCB levels in fish: An important factor in planning aquatic monitoring. Ambio. 7(2): 66-69.

Page LM, Burr BM. 1991. A field guide to freshwater fishes of North America north of Mexico. The Peterson Field Guide Series, volume 42. Houghton Mifflin Company, Boston, MA.

Pelletier C, Imbeault P, Tremblay A. 2003. Energy balance and pollution by organochlorines and polychlorinated biphenyls. The International Association for the 
Study of Obesity. Obesity Reviews. 4: 17-24.

Reid B, Jones K, Semple K. 2000. Bioavailability of persistent organic pollutants in soils and sediments - a perspective on mechanisms, consequences and assessment. Environmental Pollution. 108: 103-112.

Reinert RE. 1969. Insecticides and the Great Lakes. Limnos. 2:3-9.

Rolland R. 2000. Ecoepidemiology of the effects of pollution on reproduction and survival of early life stages in teleosts. Fish and Fisheries. 1:41-72.

Ruiz X, Llorente GA. 1991. Seasonal variation of DDT and PCB accumulation in muscle of carp (Cyprinus carpio) and eels (Anguilla anguilla) from the Ebro delta, Spain. Vie Milieu. 41: 133-140.

Rypel AL, Findlay RH, Mitchell JB, Bayne DR. 2007. Variations in PCB concentrations between genders of six warmwater fish species in Lake Logan Martin, Alabama, USA. Chemosphere. 68: 1707-1715.

SAS Institute, Inc. 1989. SAS User's Guide: Statistics, Version 6.06. SAS Institute, Inc. Cary, NC.

Selective Extraction of PCBs From Fish Tissue Using Accelerated Solvent Extraction (ASE). Dionex Application Note 322. Dionex Corporation.

Söderström M, Nylund K, Järnberg U, Lithner G, Rosén G, Kylin H. 2000. Seasonal Variations of DDT Compounds and PCB in a Eutrophic and an Oligotrophic Lake in Relation to Algal Biomass. Ambio. 29(4-5): 230-237.

Stow CA, Jackson LJ, Amrhein JF. 1997. An examination of the PCB: lipid relationship among individual fish. Canadian Journal of Fisheries and Aquatic Sciences. 54: 1031-1038.

Stow CA. 1995. Factors associated with PCB concentrations in Lake Michigan Salmonids. Environmental Science Technology. 29:522-527.

U.S. Environmental Protection Agency. 1999. United States Environmental Protection Agency. EPA-823-F-99-019, Office of Water 4305.

U.S. Environmental Protection Agency. 1998. Standard Methods for the Examination of Water and Wastewater, $20^{\text {th }}$ edition. American Public Health Association. 1-29: 1060B.

U.S. Environmental Protection Agency. 1995. Guidance for assessing chemical contaminants data for use in fish advisories, Volume I: Fish Sampling and Analysis Second Edition. USEPA, EPA 823-R-95-007, Washington DC.

Voice TC, Webber Jr WJ. 1983. Sorption of hydrophobic compounds by sediment 
soils and suspended solids. I. Theory and Background. Water Resources. 17: 1433-1441.

Wang WX, Fisher NS. 1999. Assimilation efficiencies of chemical contaminants in aquatic invertebrates a synthesis. Environmental Toxicology and Chemistry. 18: 2034-2045.

Warnick WA. 2000. West Virginia Sport Fish Consumption Advisory Guide.

West Virginia Department of Environmental Protection, Charleston.

Wellborn TL. 1998. Channel catfish: life history and biology. Southern Regional Aquaculture Center Publication 180.

Williams LL, Giesey JP, DeGalan N, Verbrugge DA, Tillitt DE, Ankley GT. 1989. Size and seasonal variations of PCBs in chinook salmon (Oncorhynchus tshawytscha) fillets from Lake Michigan near Ludinton, Michigan, U.S.A. Aquatic Toxicology Laboratory Department of Fisheries and Wildlife Pesticide Research Center Centro for Environmental Toxicology. Michigan State University. East Lansing, MI.

Zlokovitz ER, Secor DH. 1999. Effect of habitat use on PCB body burden in Judson River striped bass (Morone saxatilis). Canadian Journal of Fisheries and Aquatic Science. 56: 8693. 


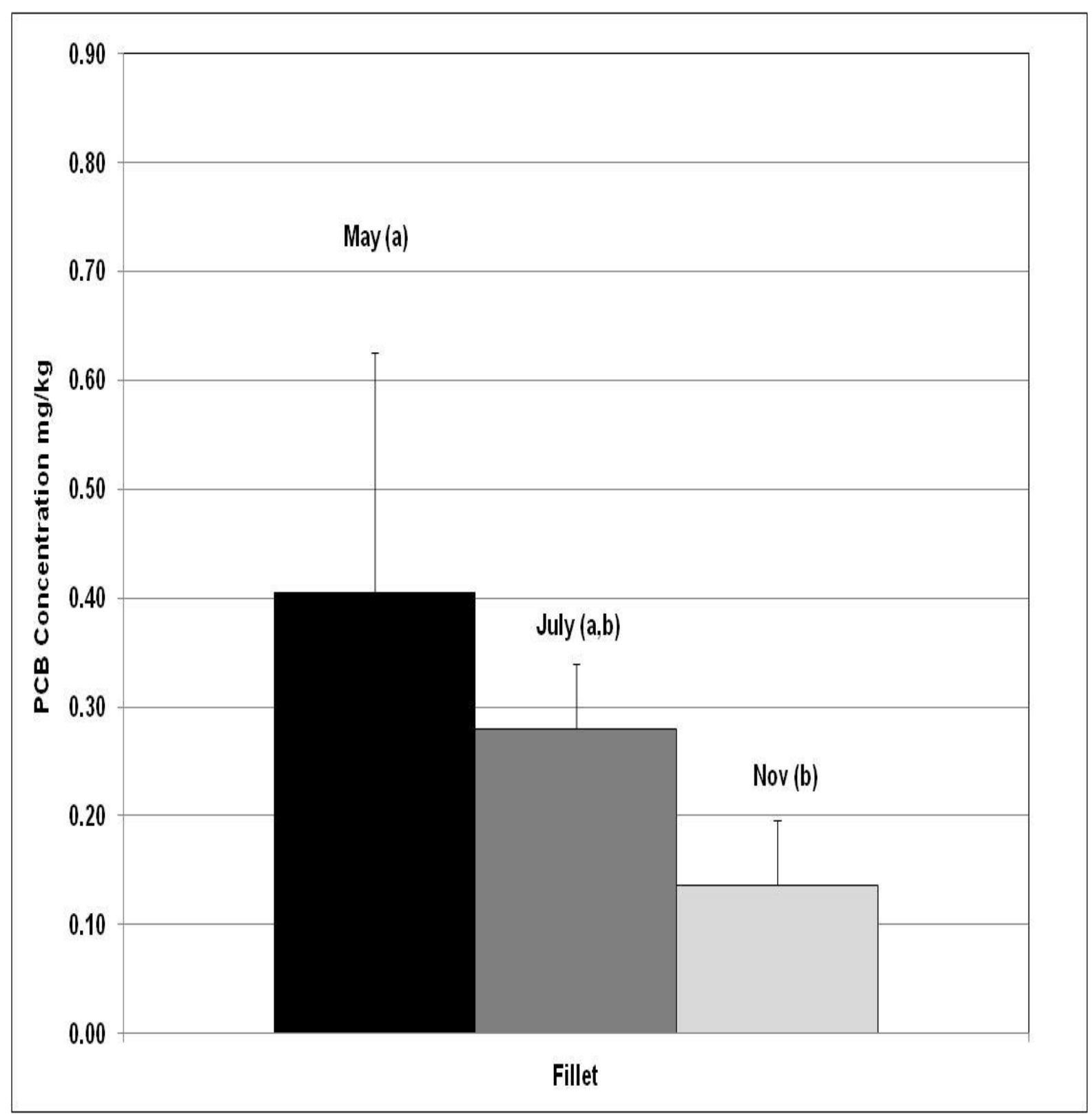

Figure 1. PCB concentration in channel catfish fillet tissues. Different letters indicate significant differences. 


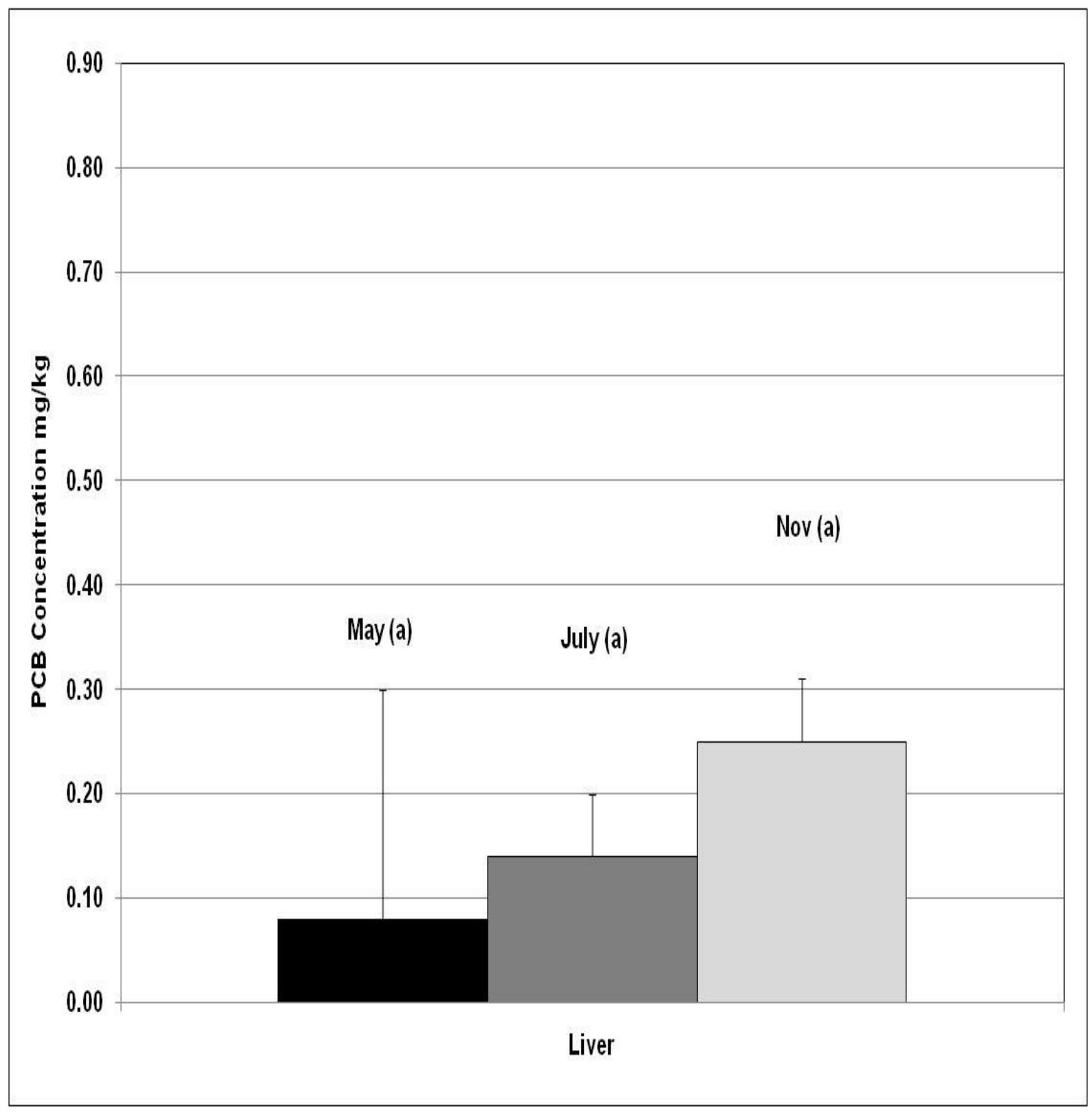

Figure 2. PCB concentration in channel catfish liver tissues. Different letters indicate significant differences. 


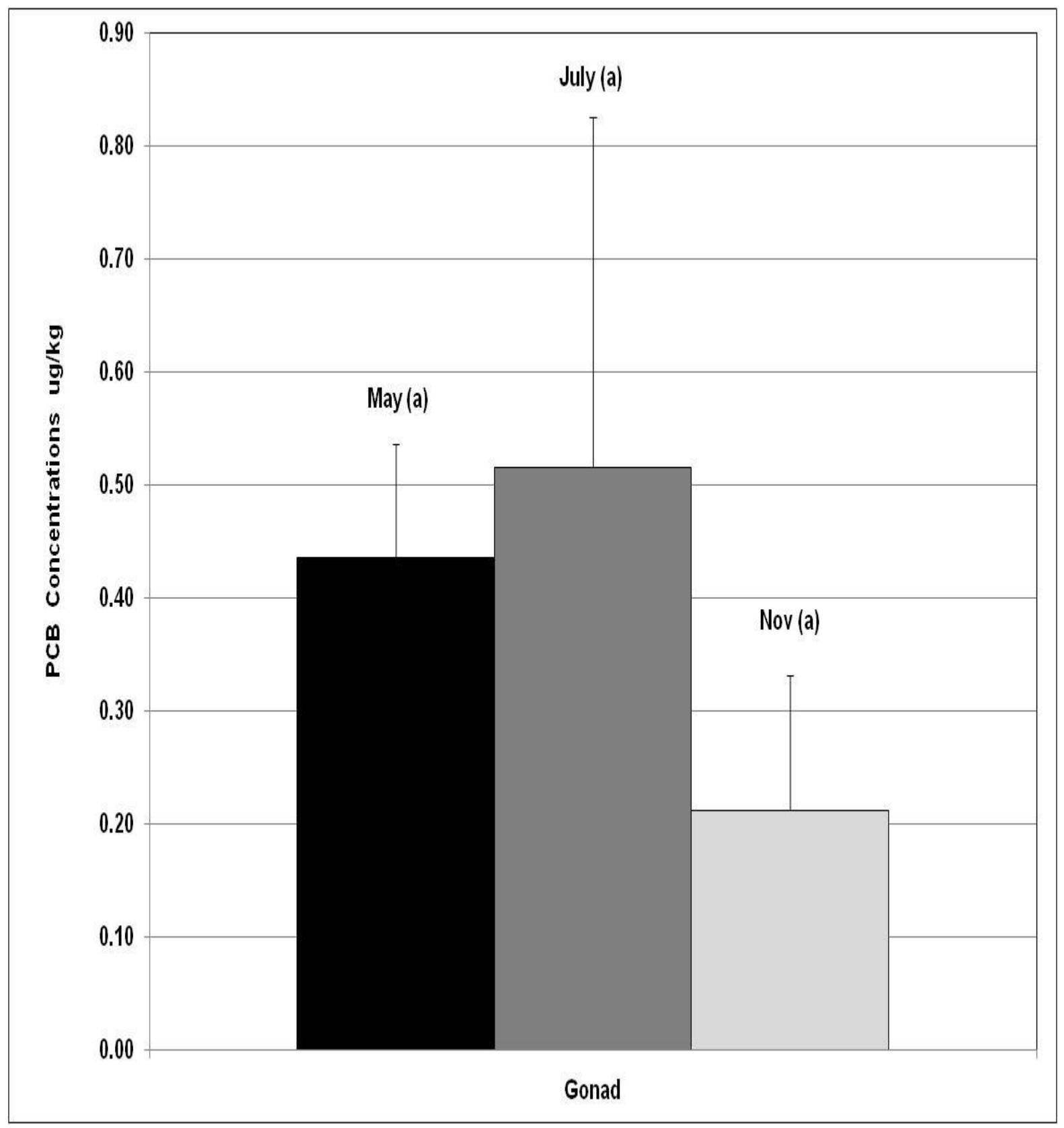

Figure 3. PCB concentration in channel catfish gonad tissues. Different letters indicate significant differences. 


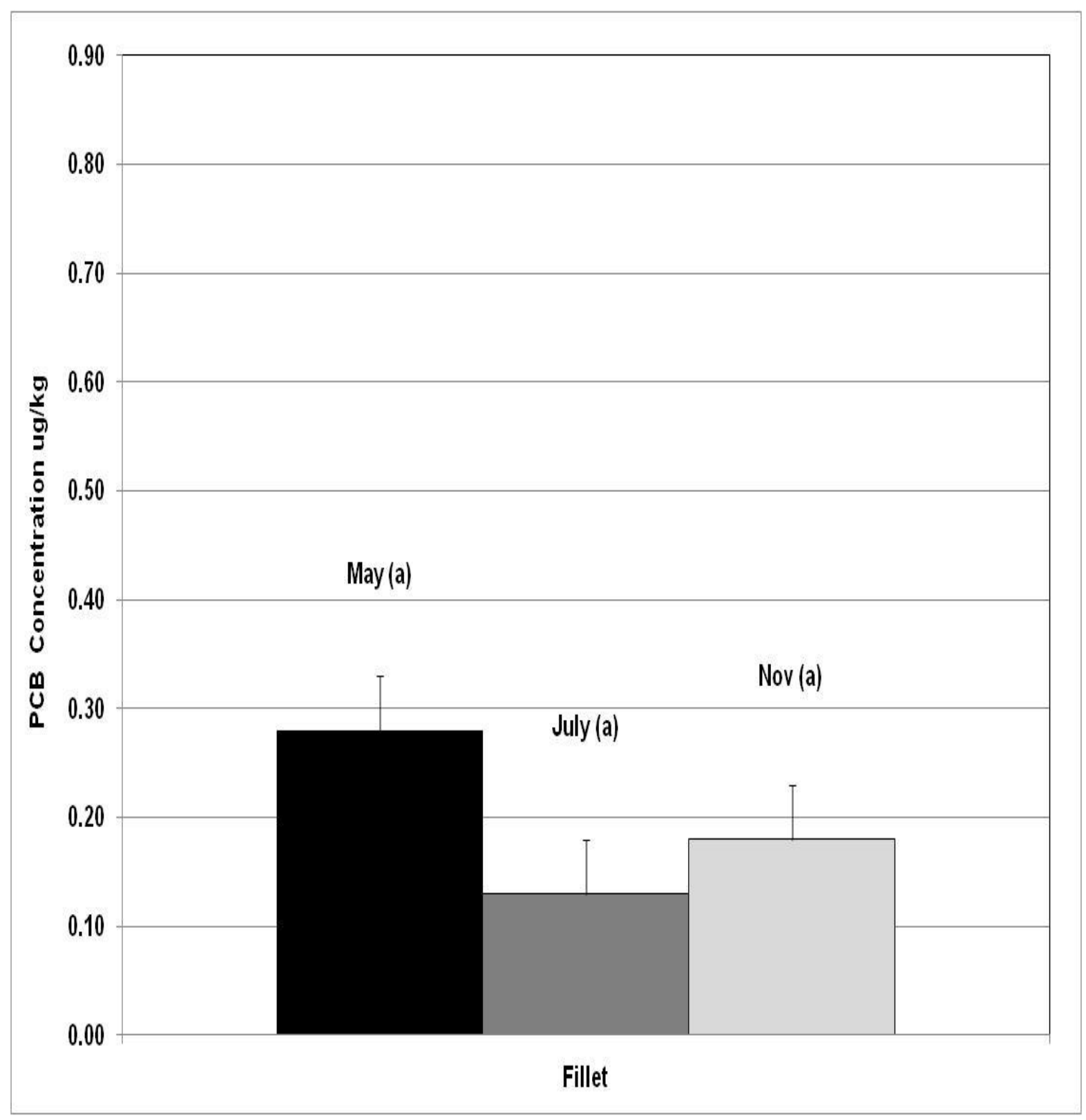

Figure 4. PCB concentration in carp fillet tissues. Different letters indicate significant differences. 


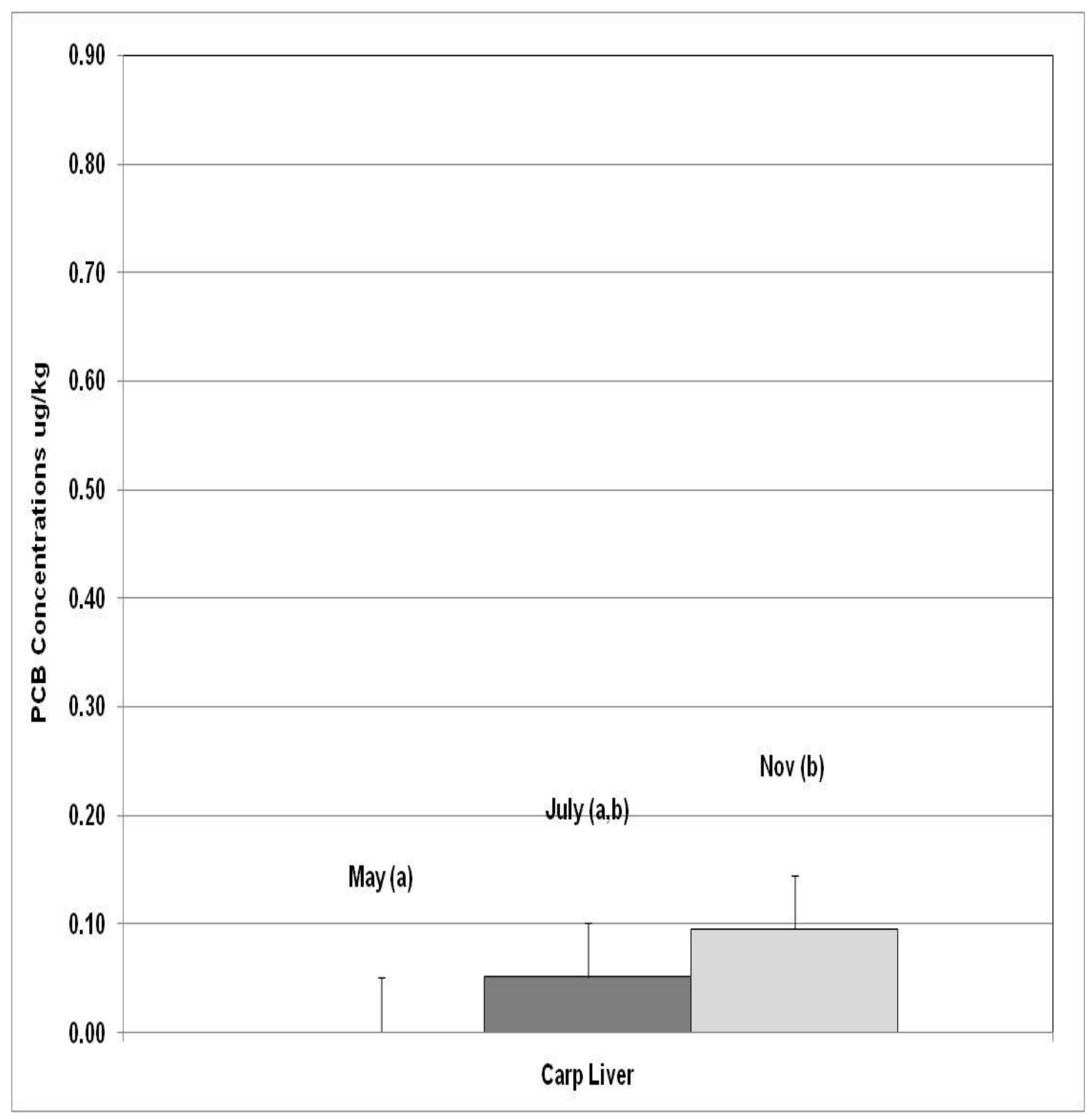

Figure 5. PCB concentration in carp liver tissues. Different letters indicate significant differences. 


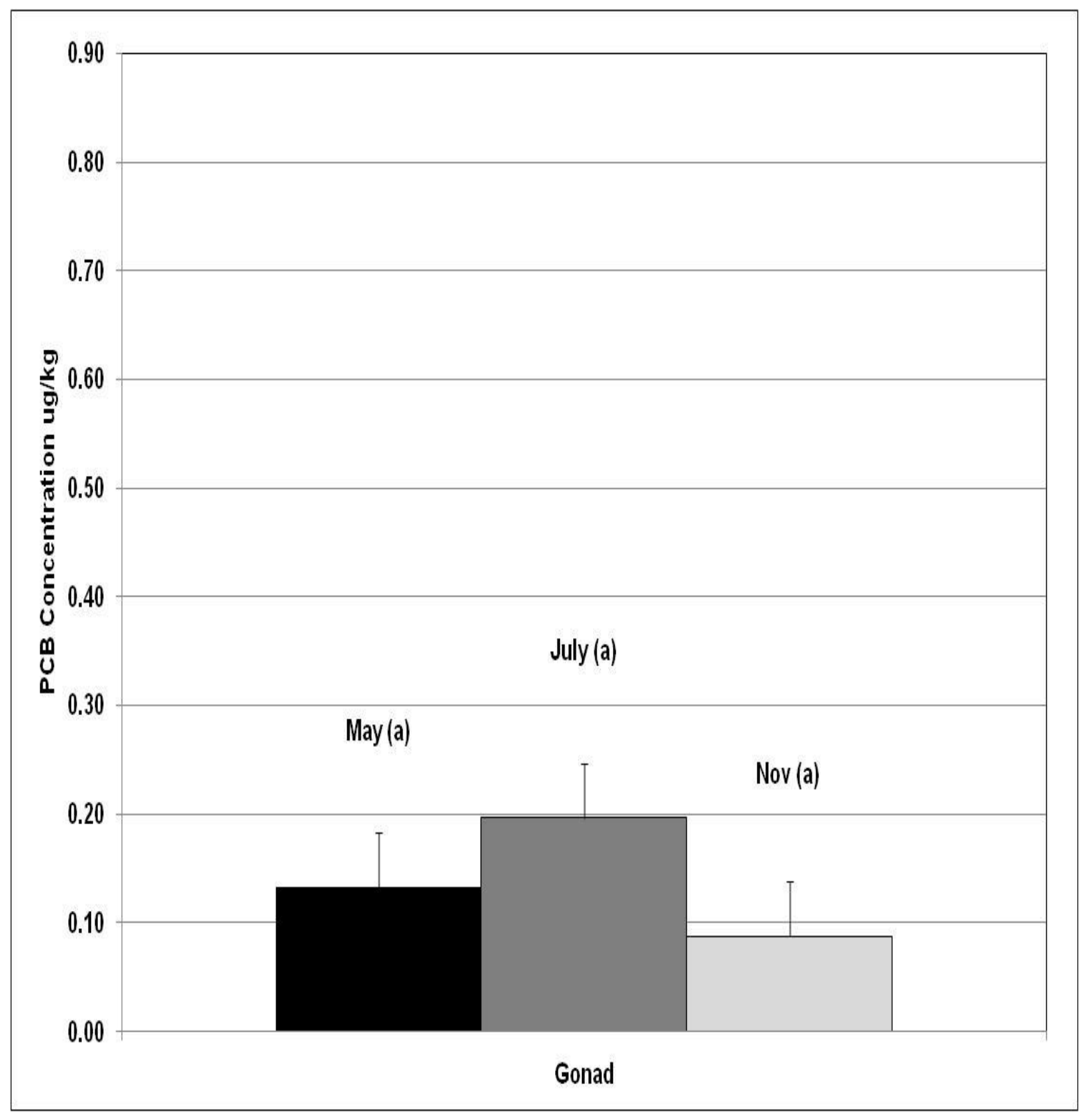

Figure 6. PCB concentration in carp gonad tissues. Different letters indicate significant differences. 


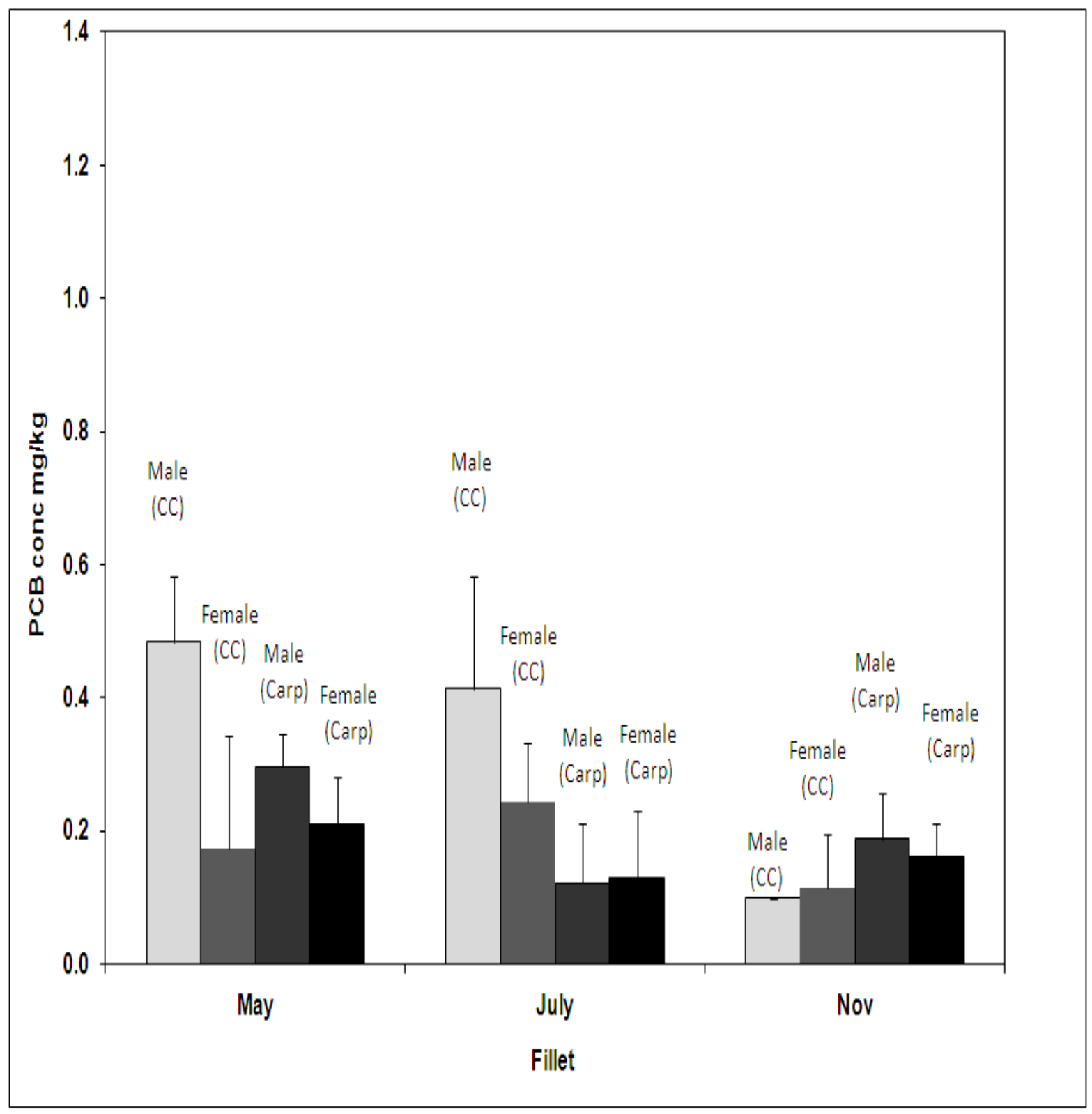

Figure 7. PCB concentration in fillets, male vs. female channel catfish and carp. No significant differences were found. 


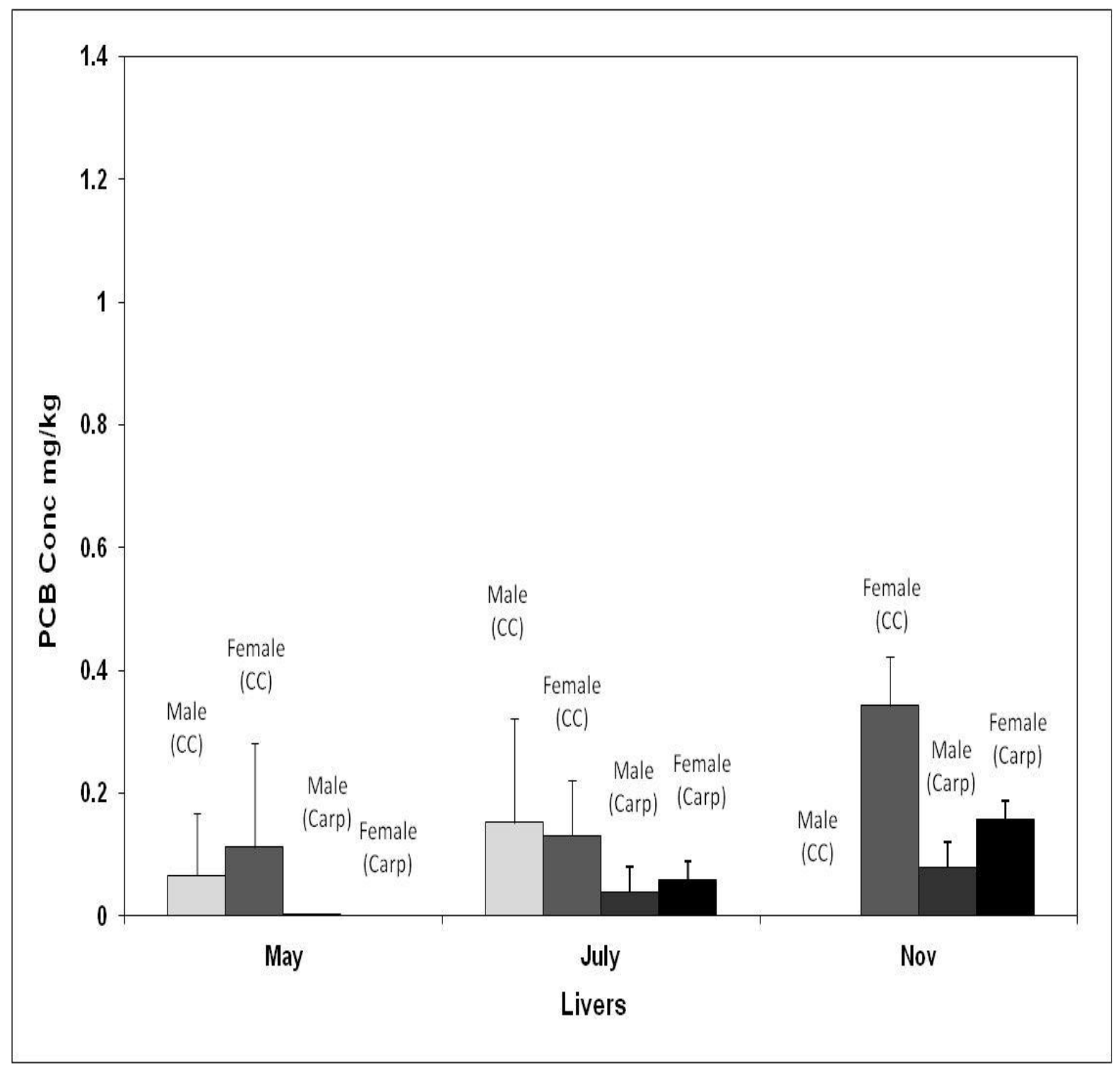

Figure 8. PCB concentration in livers, male vs. female channel catfish and carp. No significant differences were found. 


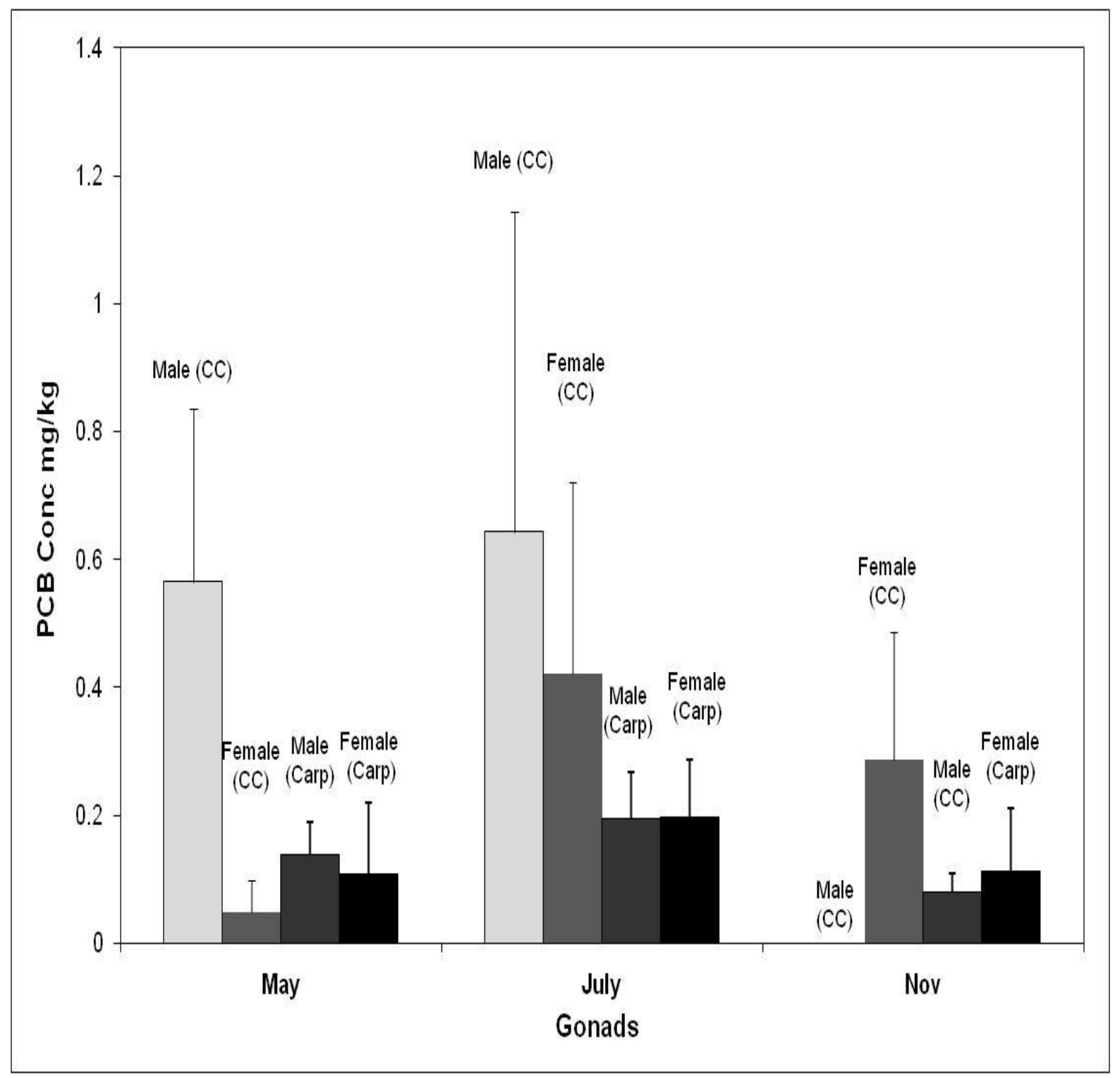

Figure 9. PCB concentration in gonads, male vs. female channel catfish and carp. No significant differences were found. 


\section{Appendix I}

\section{Field Sampling Procedures}


Quality Assurance Project Plan

For Sample Collection Activities a for

\title{
Statewide Fish Tissue Sampling and Analysis
}

\author{
Prepared for: \\ Jeff Bigler, Work Assignment Manager \\ U.S. EPA, Office of Science and Technology \\ Washington, DC 20460 \\ Prepared by: \\ Patricia M. Mazik, PhD \\ USGS/BRD \\ West Virginia Cooperative Fish \& Wildlife Research Unit \\ West Virginia University \\ 322 Percival Hall \\ Morgantown, WV 26506-6125
}


Table of Contents

I. Project Management

Project/Task Organization........................................................... 92

Problem Definition/Backgroung.....................................................93

Project/Task Description........................................................93

Quality Objectives and Criteria for Measurement Data................................... 94

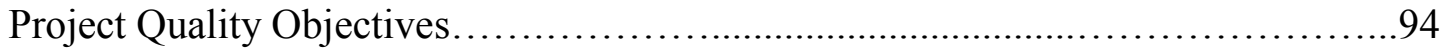

Measurement Performance Criteria.........................................................95

Special Training Requirements/Certification..........................................97

Documentation and Records........................................................97

II. Data Acquisition

Sampling Process Design....................................................... 98

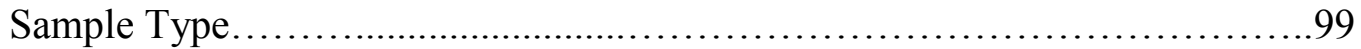

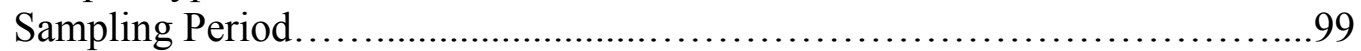

Selection of Watersheds for Sampling .............................................. 99

Sampling Methods............................................................. 100

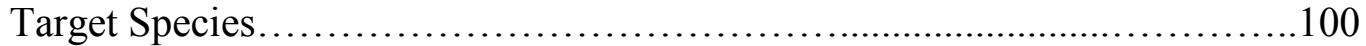

Composite Sampling......................................................... 100

Sample Collection......................................................... 100

Sample Handling and Custody Requirements..................................... 101

Sample Handling.......................................................... 101

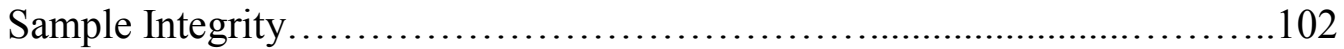

Custody Requirements................................................... 102

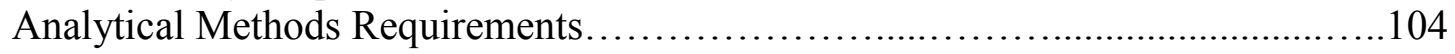

Quality Control Requirements................................................. 104

Instrument/Equipment Testing, Inspection, and Maintenance ............................104

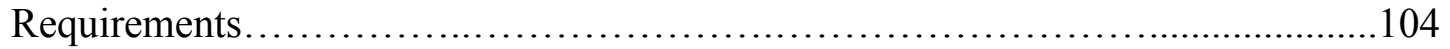

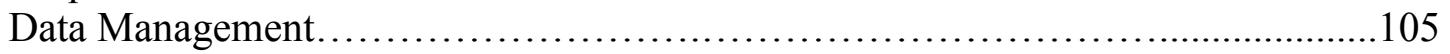

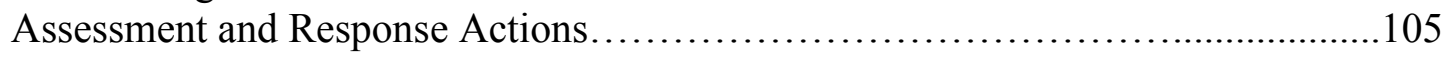

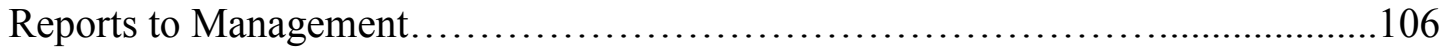

Data Review, Validation, and Verification Requirements and Methods..................106

Reconciliation with Data Quality Objectives......................................106

III. References........................................................... 107

IV. List of Figures
Figures $\ldots \ldots \ldots \ldots \ldots \ldots \ldots \ldots \ldots \ldots \ldots \ldots \ldots \ldots \ldots \ldots \ldots \ldots \ldots \ldots \ldots \ldots \ldots \ldots \ldots \ldots \ldots \ldots \ldots$

V. Standard Operating Procedures for WV Statewide Contaminant Study.....................111

Scope and Applicability................................................................111

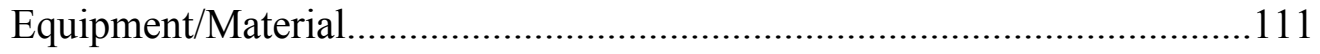

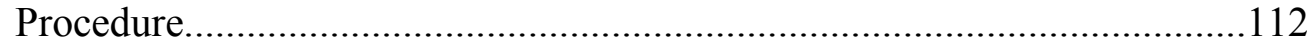




\section{PROJECT/TASK ORGANIZATION}

This Quality Assurance Project Plan (QAPP) describes the quality assurance (QA) and quality control (QC) activities/procedures that will be used while collecting samples for the West Virginia Statewide Contaminant Study (hereafter referred to as the WV contaminant study) from 2002 through 2003. The purpose of this document is to present the methods and procedures that will be used for the collection of fish tissue from watersheds in WV. This document addresses only the sample collection effort and analysis of samples for PCBs and mercury.

This QAPP was prepared according to guidance presented in the document EPA Requirements for Quality Assurance Project Plans for Environmental Data Operations, EPA QA/R-5 (USEPA 1998). Reference to the QAPP elements described in the guidance document are included herein. The sample collection methods, procedures and protocols follow the guidelines and recommendations of Guidance for Assessing Chemical Contaminant Data for Use in Fish Advisories. Volume I: Fish Sampling and Analysis, Second Edition (USEPA 2000).

The project team organization provides the framework for conducting the sample collection task to meet study objectives. The organizational structure and function also facilitate project performance and adherence to QC procedures and QA requirements. Key roles are filled by those persons responsible for ensuring the collection and processing of valid data and for routinely assessing the data for precision and accuracy, as well as the persons responsible for approving and accepting final products and deliverables. The project and QA include personnel from WV DEP, WV DNR, WV Public Health, WVU and the USGS Cooperative Fish and Wildlife Research Unit WV Coop Unit.

The USEPA Project Manager is Jeff Bigler who will supervise the project for USEPA.

The WVU Project Manager is Dr. Patricia Mazik, who will supervise the assigned project personnel to provide for their efficient utilization by directing their efforts either directly or indirectly. As Project Manager she will have the following responsibilities:

1. provides oversight for study design, sample collection and adherence to design objectives,

2. reviewing and approving the project work plan, QAPP, and other materials developed to support the project,

3. coordinating project assignments in establishing priorities and scheduling, 
4. ensuring completion of high-quality projects within established budgets and time schedules,

5. providing guidance, technical advice and performance evaluations to those assigned to the project,

6. implementing corrective actions and providing professional advice to staff,

7. preparing and/or reviewing preparation of project deliverables.

The DEP Project Manager/QA Officer is Janice Smithson, who will be responsible for overseeing the project and also serving as Quality Assurance Office. In this position, she will be responsible reviewing and approving all Quality Assurance Project Plans (QAPP). Additional responsibilities include the following:

Conducting external performance and system audits of the procedures

Monitoring quality control (QC) activities to determine conformance

Reviewing QAPP for completeness and noting inconsistencies

Providing support to USEPA and WVU Project Manager in preparation of the work plan and QAPP and in their distribution, and

Approving the QAPP.

The Senior Fishery Biologist at each sample site will be responsible for following the work plan and assuring that the sampling procedures in the QAPP are followed.

Field Sampling Teams will be composed of:

A DNR fishery biologist and/or,

WVU fisheries personnel.

\section{Problem Definition/Background}

West Virginia has recently formed a West Virginia Interagency Fish Consumption Advisory Technical Committee to address the state's fish consumption advisory issues. The cooperatives are ready to implement the state's new consumption advisory protocols, developed by West Virginia University (WVU) and presented in "West Virginia Sport Fish Consumption Advisory Guide". However, the committee is faced by a lack of data in many waters. A review of the historic data indicates that mercury and PCBs are the most prevalent pollutants of concern. Since West Virginia needs to maximize the geographic coverage for fish tissue data, it is desirable to collect data in as many places as possible for these limited parameters. 


\section{Project/Task Description}

This study design reflects the study goals and objectives defined by the West Virginia Interagency Fish Consumption Advisory Technical Committee (WV Interagency Committee). The study goal is to determine the extent to which fish in the watersheds of WV are contaminated with PCBs and mercury. The project field sampling tasks presented and discussed in this document involves only those methods and procedures used to collect and transport fish tissue samples for the WV study. The Chemical Analysis QAPP for the WV study discusses sample preparation, compositing and homogenization and analytical methods for determination of mercury and PCBs.

Sample sites and species will be collected as determined by the WV Interagency Committee. Sample sites will be representative of watersheds in WV. The following elements will be considered when planning field logistics:

Field teams must consist of (at a minimum) one experienced fisheries biologist, one field technician, and a quality control specialist, all of which must have experience with the array of fisheries sampling gear types to be used. In some cases the fishery biologist or the technician may serve in dual capacities, also assuming responsibility for quality control. In most cases, the fishery biologist will be from a state agency and the field technician from WVU.

The study will include 2 groups of target fishes - predator/gamefish and bottomdwelling fish species.

Samples must consist of a composite of fish (e.g. 6 individuals) of the same target species and be of the same relative size from each sample location.

Sampling activities are expected to begin in the spring of 2002 and continue through summer 2003. The final study report is scheduled to be completed September 2003. All activities associated with fish tissue sample collection will be conducted as stated in this QAPP as approved by the EPA Project manager.

\section{Quality Objectives and Criteria for Measurement Data}

\section{Project Quality Objectives}

Data of known and documented quality are essential to the success of any sampling program. Data quality objectives (DQOs) are qualitative and quantitative statements that clarify the intended use of the data, define the type of data needed to support the decision, identify the conditions under which the data should be collected and specify tolerable limits on the probability of making a decision error due to uncertainty in the data. DQOs are developed by the data users to specify the data quality needed to support specific decisions. Sources of error or uncertainty include the following: 
Sampling error: The difference between sample values and in situ true values from unknown biases due to collection methods and sampling design,

Measurement error: The difference between sample values and in situ true values associated with the measurement process,

Natural variation: Natural spatial heterogeneity and temporal variability in population abundance and distribution, and

Error sources or biases associated with compositing, sample handling, storage, and preservation.

This QAPP addresses only fish tissue sample collection activities, so the relevant quality objectives are primarily related to sample handling issues. Types of field sampling dtat needed for this project are listed in Table 1. Discussion of conventional data quality indicators (i.e. precision, accuracy, completeness, representativeness, and comparability) follows in this section. Methods and procedures described in this document are intended to reduce the magnitude of the sources of uncertainty (and their frequency of occurrence) by applying the following approaches:

Use of standardized sample collection and handling procedures, and

Use of trained biologists to perform the sample collection and handling activities.

Table 1. Types of field data to be collected in association with fish tissue sample collection.

\begin{tabular}{|l|l|}
\hline Data type & Measurement Endpoint(s) or Units \\
\hline Fish specimen & Species-level taxonomic identification \\
\hline Fish length & Millimeter (mm), total length \\
\hline Composite classification & Predator or bottom-dwelling species \\
\hline
\end{tabular}

\section{Measurement Performance Criteria}

Measurement performance criteria are quantitative statistics that are used to interpret the degree of acceptability or utility of the data to the user. These criteria, also known as data quality indicators (DQIs), include the following:

Precision,

Accuracy,

Representativeness.

Completeness, and

Comparability 


\section{Precision}

Precision is a measure of internal method consistency. It is demonstrated by the degree of agreement between individual measurements (or values) of the same property of a sample, measured under similar conditions. Precision, as pertaining to analytical testing, will be discussed in Appendix II. Sufficient sample volumes will be (the six fish composites described in Section 8.2) collected to allow for the assessment of precision during analytical laboratory testing. The sampling crews will be trained on the process of sampling so the methods can be standardized as much as possible.

\section{Accuracy}

Accuracy is defined as the degree of agreement between an observed value and an accepted reference or true value. Accuracy is a combination of random error (precision) and systematic error (bias), introduced during sampling and analytical operations. Bias is the systematic distortion of a measurement process that causes errors in one direction, so that the expected sample measurement is always greater or lesser to the same degree than the sample's true value. Accuracy in analytical procedures will be discussed in Appendix II. Proper sample handling procedures (Section 9.1) will be followed to minimize sample contamination.

Representativeness

Representativeness expresses the degree to which data accurately and precisely represents a characteristic of a population, parameter, variations at a sampling point, a process condition or an environmental condition.

Representativeness of the target species (Section 8.1) for this fish tissue sampling effort was established based on:

The recommendation of USEPA's Guidance for Assessing Chemical Contaminant

Data for Use in Fish Advisories, Volume 1: Fish Sampling and Analysis, Second

Edition (USEPA 2000),

Approval by WV interagency committee, and

Approval by the USEPA Project Manager.

The representative goal for the sample collection effort will be satisfied by using experienced field biologists to ensure that the sample types and locations specified for the study are the samples actually collected.

\section{Completeness}


Completeness is defined as the percentage of measurements made that are judged to be valid according to specific criteria and entered into the data management system. To optimize completeness, every effort is made to avoid sample and/or data loss. Accidents during sample transport or laboratory activities that cause the loss of the original samples will result in irreparable loss of data, which will reduce the ability to perform analyses, integrate results and prepare reports. Samples will be stored and transported in unbreakable containers (i.e., insulated ice chests). All sample processing (i.e., compositing, filleting, homogenization) will occur in a controlled environment within the laboratory, not in the field. The assignment of a set of specific sample numbers (Section 6.0) that have undergone chain-of-custody inspection makes it less likely for the preparation laboratory to overlook samples when preparing them for processing.

\section{Comparability}

Comparability is an expression of the confidence with which one data set can be compared with another. Comparability is dependent on the proper design of the sampling program on adherence to accepted sampling techniques, standard operating procedures, and quality assurance guidelines. Comparability of data will be accomplished as follows:

All field personnel involved with sampling will have adequate training and appropriate experience (Section 5.0), and

All samples will be collected and prepared for shipment according to standard operating procedures contained in this QAPP. These procedures are consistent with the recommendations of USEPA's Guidance for Assessing Chemical Contaminant Data for Us5 in Fish Advisories, Volume 1: Fish Sampling and Analysis, Second Edition (USEPA 2000).

\section{Special Training Requirements/Certifications}

Each Field Sampling Team is required to have the necessary knowledge and experience to perform all field activities. This includes both knowledge and experience in the collection and identification of fishes, in the use of fisheries sampling gear specified for the study and in the operation of small boats. It also included training in project-specific sample collection and handling procedures. The field sampling crews will be primarily composed of state fishery biologists with a strong technical background in fisheries sampling activities. Each Field Sampling Team must consist of (at a minimum) one experienced fisheries biologist, one field technician, and a quality control specialist, all of which must have experience with the array of fisheries sampling gear types to be used. In some cases the fishery biologist or the technician may serve in dual capacities, also assuming responsibility for quality control. In most cases, the fishery biologist will be from a state agency and the field technician from WVU.

\section{Documentation and Records}


Through documentation of all field sample collections and handling activities is necessary for proper processing in the laboratory and, ultimately, for the interpretation of study results. Field sample collection and handling will be documented in writing (for each sample site) using the following forms and labels"

A Field Record Form that contains information about each individual specimen and sampling site (Figure 1),

A Sample Identification Label that accompanies and identifies each sample (Figure 2),

A Chain-of-Custody Label that seals each sample container (Figure 3), and

A Chain-of-Custody Form that provides tracking information for all samples (Figure 4).

The Field Record Form will be placed in the sample cooler for transport to WVU. At WVU a copy will be made and kept by WVU Project Manager. The Field Record Form will be on "rite in the rain" paper and no erasures will be made. Any incorrect entries will be crossed out and initialed and dated by the recorder.

A Sample Identification Label will be completed for each sample throughout the chain of custody. In most cases a WVU technician will be at the sampling site and will transport the samples back to WVU. At other times, the WVU technician will receive the samples from the WV DNR biologist that collected the samples. The Sample Identification Label will be placed in the foil wrapped individual fish and contain the sampler's name, sampling site location, sample date and time, species collected and specimen number (e.g., $01-06)$. All entries will be made on "rite in the rain" paper and information will coincide with information on the Field Record Form.

Proper chain-of custody procedures are necessary for tracking sample possessions from field to laboratory. Chain-of-Custody Forms (Figure 4) will accompany each shipment of samples back to WVU and will contain sample identity (coinciding with information on the Field Record Form), sampler relinquishment data and time, and arrival at WVU laboratory data and time. All Chain-of-Custody Labels will be attached to each composite sample following packing in the field, and will include the signature of the sampler and date and time sealed. If a WVU technician is not at the sampling site, arrangements will be made prior to sampling for WVU to pick up the samples.

If any change(s) in the QAPP is(are) required during the study, a memo will be sent to each person on the distribution list describing the change(s), following approval by the USEPA Project Manager. Any and all memos announcing changes must be attached to the QAPP. 
All documents and records prepared for this project will be maintained by WVU during the project, and retained for a period of two years following completion of the project (unless otherwise directed by USEPA).

\section{Sampling Process Design}

The objective of the WV Statewide Contaminant Study is to determine the extent to which fish in the watersheds of WV are contaminated with PCBs and mercury. The target watersheds will be sampled over the project duration.

\section{Sample Type}

To meet the study objectives, the WV Statewide Contaminant Study will use composite sampling of fish fillets for predator/gamefish and bottom-dwelling species from each watershed sampled. Six individuals per composite ( 3 composite per predator and 3

composites per bottom-dweller at each sampling site) will be collected, all of which will be large enough to provide sufficient tissue for analysis of mercury and PCBs. Based on the USEPA's Guidance for Assessing Chemical Contaminant Data for Use in Fish Advisories, Volume 1: Fish Sampling and Analysis, Second Edition (USEPA 2000), fish used in a composite sample must meet the following criteria:

Be all of the same species,

Satisfy any legal requirements of harvestable size or weight, or at least be of consumable size of no legal harvest requirements are in effect,

Be of similar size so that the smallest individual in a composite is no less than $75 \%$ of the total length of the largest individual,

Be collected at the same time (i.e., collected as close to the same time as possible, but no more than 1 week apart) [Note: This assumes that a sampling crew as unable to collect all fish needed to prepare the composite sample on the same day. If organisms used in the same composite are collected on different days (no more than 1 week apart), individual fish will be frozen until all the fish to be included in the composite are available for delivery to the laboratory.], and

Be collected in sufficient numbers (six per composite) and of adequate size (six harvestable size adult fish) to allow analysis of mercury and PCBs.

\section{Sample Period}

Fish will be sampled from Spring 2002 until August 2003. Field sampling will be coordinated with the WV DNR and WVU.

\section{Selection of Watersheds for Sampling}


The watersheds, and which rivers, lakes and reservoirs within each watershed to be sampled, were determined by the WV Interagency Committee. Specific species (predator

and bottom-dwelling) to be sampled in each system were also determined by the Committee.

\section{Sampling Methods}

\section{Target Species}

Field sampling procedures will follow the recommendations of USEPA's Guidance for Assessing Chemical Contaminant Data for Use in Fish Advisories, Volume 1: Fish Sampling and Analysis, Second Edition (USEPA 2000). According to the guidance, the primary criteria for selection target fishes is that the species:

Are commonly consumed in the study area,

May potentially accumulate high concentrations of chemicals, and

Have a wide geographic distribution.

Secondarily, the target species should be:

Easy to identify,

Abundant

Easy to capture, and

Large enough to provide adequate tissue for analysis (six fish of harvestable size).

Two distinct groups of fish, predators and bottom-dwellers, will be included as target fish in this study.

\section{Composite Sampling}

The WV Statewide Contaminant Study will involve composite sampling of predator and bottom-dwelling species (to be prepared as fillet composites). Composite samples are cost-effective for estimating average tissue concentrations of mercury and PCBs and compositing ensures adequate sample size for analytical analysis. Fish retained for a composite sample must meet the following criteria:

Be all of the same species,

Satisfy any legal requirements of harvestable size or weight, or at least be of consumable size of no legal harvest requirements are in effect, 
Be of similar size so that the smallest individual in a composite is no less than $75 \%$ of the total length of the largest individual,

Be collected at the same time (i.e., collected as close to the same time as possible, but no more than 1 week apart) [Note: This assumes that a sampling crew as unable to collect all fish needed to prepare the composite sample on the same day. If organisms used in the same composite are collected on different days (no more than 1 week apart), individual fish will be frozen until all the fish to be included in the composite are available for delivery to the laboratory.], and

Be collected in sufficient numbers (six per composite) and of adequate size (six harvestable size adult fish) to allow analysis of mercury and PCBs.

Accurate taxonomic identification is essential in assuring and defining the fish that have been composited and submitted for analysis. Under no circumstances will individuals from different species be used in a single composite. Ideally, the target species composite will focus on the larger individuals commonly caught by the local population.

\section{Sample Collection}

Fish collection methods can be divided into two major categories, active and passive. Each has advantages and disadvantages. Active collection methods employ a wide variety of sampling devices including electrofishing boats and backpack units, seines, trawls, and angling equipment (hook and line). Although active collection requires greater fishing effort, it is usually more efficient than passive collection for covering a large number of sites and catching the relatively small number of fish needed from each site for tissue analysis. The active collection methods generally require more field personnel and more expensive equipment than passive collection methods. Passive collection methods employ a wide array of sampling devices, including gill nets, fyke nets, trammel nets, hoop nets, pound nets and d-traps. Passive collection methods generally require less fishing effort than active methods, but can yield a much greater catch that would be required for a contaminant monitoring program. They are also time- consuming to deploy. Passive collection methods must be checked frequently to ensure a limited time lag between fish entrapment and sample preservation. Selection of the most appropriate type of sampling method and gear for a particular sample site will be at the discretion of the experienced on-site fishery biologist.

Fish will be identified to species as soon as collected by an experienced fishery biologist. Non-target species will be returned to the water. Upon collection, target species will be rinsed in ambient water to remove any foreign material and placed in a clean container. Each fish will be measured to determine total body length (mm). When sufficient numbers of the target species (6 fish) have been identified to make up a suitable composite, the species name, lengths and all other site and sampling information will be recorded on the Field Record Form (Figure 1).

\section{Sample Handling and Custody Requirements}




\section{Sample Handling}

Fish of selected target species should be rinsed in ambient water to remove any foreign material from the fish. After species identification and determining length, each of the six fish found to be suitable for the composite sample will be individually wrapped in extra heavy-duty aluminum foil. A Sample Identification Label (Figure 2) will be prepared for each foil wrapped fish. Each foil wrapped fish will be placed into a plastic zip-lock bag with the completed Sample Identification Label. All fish for one composite will be placed in a large zip-lock plastic bag and placed on ice in a ice chest. Sampling teams have the option to:

Freeze the samples within 24 hours of collection if transport to WVU cannot occur that day. WVU Project Manager is then contacted for pick up of samples.

The time of sample collection, relinquishment by the sample team, and time of arrival by WVU laboratory must be recorded on the Chain-of-Custody Form.

\section{Sample Integrity}

A critical requirement of the WV Statewide Contaminant Study in the maintenance of sample integrity from the time of collection the shipment and arrival at the WVU laboratory. Sample integrity is maintained by preventing the loss of contaminants that might be present in the sample and by taking precautions to avoid possible introduction of contaminants during handling. The loss of contaminants can be prevented in the field by ensuring that the samples collected remain intact (i.e., sample collection methods should be performed with the intention of minimizing the laceration of fish skin). Once a sample is collected, sample integrity is maintained through careful and controlled sample handling, storage, and preservation procedures (Section 9.1).

Preventable sources of extraneous contamination can include the sampling gear, oils and greases on boats, spilled fuel, skin contact, contact with soil or sand, boat motor exhaust, and other potential sources. All potential sources should be identified before the onset and during sample collection, and appropriate measures should be taken to minimize or eliminate them. Examples of preventative measures include the following:

Collection nets should be free of any potential contaminants,

The use of tarred collection nets is prohibited,

Boats should be positioned so that engine exhaust does not fall on the deck area where samples are being handled,

Ice chests and other sample storage containers should be cleaned before use, 
Samples should not be placed directly on ice, but should be stored inside foil and then plastic zip-lock bags first, and

Proper gloves should be used when handling fish samples.

\section{Custody Requirements}

As soon as possible following collection, the Sampling Team will begin the process of identifying, labeling, packaging, and storing the samples. Each sample (i.e., individual fish will be labeled by affixing a Sample Identification Label (Figure 2) as per the instructions in Section 9.1. The sample label will accompany each sample throughout the chain-of-custody. Each sample label will include the following information:

Project name (WV Statewide Contaminant Study),

Site identification (i.e., river name),

Sample number (01-06),

Date of sample (month/day/year),

Time of collection (military time)

Preservation used (ice), and

Collector's name (lead fishery biologist)

Detailed documentation of samples collected in the field and information about the collection location will be recorded on a Field Record Form (Figure 1). One form must be completed for each sample composite and will be sent with the composite to WVU. A copy will be made at WVU and kept by WVU Project Manager. The original will remain in the data notebook. The form will be copied on "rite in the rain" paper. Any entry mistakes will be crossed out (not erased) and initialed and dated. Each Field Record Form will have the following information:

Sampling date,

Time of collection (military time),

Collection method (e.g., gill nets),

Collector's name (printed and signed),

Collector's affiliation and phone number

Site name and location (i.e., river name, mile), 
Fish species (common name),

Length (mm) of each fish, and

Location, date and time of collection for each fish.

All samples will be transferred to the WVU laboratory under chain of custody. The form will be attached to the ice chest and all entries will include:

The USEPA Project Manager's name, address, and phone number (refer to QAPP cover page),

Sampler's name and phone number,

Project name (WV Statewide Contaminant Study),

Page number (i.e., 1 of 1 ),

Sample location (river name),

Collection time and date,

Preservation (ice),

Number of containers

Sampler's signature, date and time,

Sampler relinquishment date and time

Laboratory recipient signature, and

Laboratory receipt date and time.

\section{Analytical Methods Requirements}

Samples will be shipped (Section 9.1) under chain of custody to the WVU laboratory for analytical testing of mercury and PCBs. Composite samples will be analyzed for PCB residues according to the FDA's Pesticide Analytical Manual (PAM). Composites for mercury will be analyzed for total mercury using hot acid digestion and cold vapor atomic absorption according to Evans et al. (1986).

\section{Quality Control Requirements}


Data quality is addressed, in part, by consistent performance of valid procedures documented in the field and laboratory standard operating procedures (Appendix D). It is enhanced by the training and experience of the project staff (Section 5.0) and documentation of project activities (Section 6.0).

\section{Instrument/Equipment Testing, Inspection and Maintenance Requirements}

All field equipment will be inspected prior to sampling activities to ensure that proper use requirements are met (e.g., boats operating correctly, etc.). Field equipment will be inspected well in advance of the sampling to allow for repair and/or replacement of defective equipment.

\section{Data Management}

Samples will be documented and tracked via Sample Identification Labels, Field Record Forms, and Chain-of-Custody Forms (Section 6.0). Field team leaders will be responsible for reviewing all completed forms. Any corrections should be noted, initialed and dated by the reviewer (Section 6.0). Upon receiving the samples, the WVU laboratory will retain one copy of the Field Record Form and the Chain-of-Custody Form, and will forward a copy to WVU Project Manager. All forms obtained by WVU will be maintained for a period of 2 years following completion of the project (unless otherwise directed by USEPA).

\section{Assessment and Response Actions}

Assessment activities and corrective response actions have been identified to ensure that sample collection activities are conducted as prescribed and that the measurement quality objectives and data quality objectives established are met. The QA program includes performance and system audits with independent checks of the data obtained from sampling activities. Either type of audit could indicate the need for corrective action. The essential steps in the program are as follows:

identify and define the problem,

assign responsibility for investigating the problem,

investigate and determine the cause of the problem,

assign and accept responsibility for implementing appropriate corrective action,

establish effectiveness of and implement the corrective action, and

verify that the corrective action has eliminated the problem. 
Immediate corrective actions form part of normal operating procedures and are noted on project Field Record Forms. Problems not solved this way require formalized, long-term corrective action. In the event that quality problems requiring attention are identified, the WVU Project Manager will determine whether attainment of acceptable data quality requires either short- or long-term actions.

Performance audits are qualitative checks on different segments of project activities, and are most appropriate for sampling, analysis, and data processing activities. Performance audit techniques include checks on sampling equipment, measurements, and the analysis of data quality using QC and spiked samples. The WVU Project Leader will be responsible for overseeing work as it is performed, and periodically conducting QC checks during the sample collection phase of this project.

\section{Reports to Management}

A final report will be due to the DEP Project Manager/QA Officer and USEPA Project Manager at the completion of the project in September 2003.

\section{Data Review, Validation and Verification Requirements and Methods}

Data validation and review provides a method for determining the usability and limitations of data, and provide a standardized data quality assessment. All Field Record Forms and Chain-of-Custody forms will be reviewed by the WVU Project Manager for completeness and correctness. Data quality will be assessed by comparing entered data to original data to determine whether to accept, reject or quality the data. WVU will be responsible for reviewing data entries.

\section{Reconciliation with Data Quality Objectives}

As soon as possible following sample collection, data quality will be assessed by WVU and compared with the criteria discussed in Section 4.0. This will be the final determination of whether the data collected are of the correct type, quantity, and quality to support their intended use for this project. Any problems encountered will be discussed with the DEP Project Manager/QA Officer and the USEPA Project Manager.

\section{References}

Evans SJ, Johnson MS, and Leah RT. 1986. Determination of Mercury in Fish Tissue, a Rapid, Automated Technique for Routine Analysis. Varian Instruments at Work; AA-60: 1 6.

U.S. Environmental Protection Agency (USEPA). 2000. Guidance for Assessing Chemical Contaminant Data for Use in Fish Advisories, Volume 1: Fish Sampling and Analysis, Second Edition, USEPA, Office of Water, Washington DC EPA 823-R-92-008. 
U.S. Environmental Protection Agency (USEPA). 1998. EPA Requirements for Quality Assurance Project Plans for Environmental Data Operations, USEPA, Quality Assurance Division, Washington, DC. EPA/QA/R-5.

U.S. Food and Drug Administration. 1985. Pesticide Analytical Manual (PAM) Volume I. FDA, Washington, D.C.

U.S. Food and Drug Administration. 1985. Pesticide Analytical Manual (PAM) Volume II. FDA, Washington, D.C. 
Figure 1. The Field Record Form will be placed in the sample cooler for transport to WVU.

\section{Field Record Form}

WEST VIRGINIA STATEWIDE CONTAMINANT STUDY

Field Record Form

Sampling Date (mm/dd/yy) and Time (military)

\section{Site Location}

Waterbody Name and ID (river mile):

County: Lat./Long.:

Waterbody type:

River

Lake

Other

Site Description:

Collection method:

Collector's name (print and sign):

Address and Phone \#:

\section{Fish collection}

Bottom-dwellers - Species name:

Composite sample \#1

Fish \# Length (mm)

2

3

4

5

6
Composite sample \#2

Fish \# Length (mm)

1

2

3

4

5

6
Composite sample \#3

Fish \# Length (mm)

1

2

3

4

5

6 


\begin{tabular}{|c|c|c|c|}
\hline \multicolumn{4}{|c|}{$\begin{array}{l}\text { Maximun size } \\
\text { Notes (e.g., morphological anomalies): }\end{array}$} \\
\hline \multicolumn{4}{|l|}{ Predator - Species name: } \\
\hline Composite sample \#1 & Composite sample \#2 & Composite sample \#3 & \\
\hline $\begin{array}{l}\text { Fish \# Length }(\mathrm{mm}) \\
1\end{array}$ & $\begin{array}{l}\text { Fish \# Length (mm) } \\
1\end{array}$ & $\begin{array}{l}\text { Fish \# Length (mm) } \\
1\end{array}$ & \\
\hline 2 & 2 & 2 & \\
\hline 3 & 3 & 3 & \\
\hline 4 & 4 & 4 & \\
\hline 5 & 5 & 5 & \\
\hline 6 & 6 & 6 & \\
\hline
\end{tabular}

\section{Minimun size}

Maximun size

$$
\mathrm{X} 100=
$$
$>75 \%$ Composite mean Length $\mathrm{mm}$

Notes (e.g., morphological anomalies):

Comments:

Figure 2. The Sample Identification Label will be placed in the foil wrapped individual fish and contain the sampler's name, sampling site location, sample date and time, species collected and specimen number (e.g., $01-06)$. All entries will be made on "rite in the rain" paper and information will coincide with information on the Field Record Form.

Sample Identification Label (placed in foil of each individual fish sample)

\begin{tabular}{|c|c|c|c|}
\hline \multicolumn{4}{|c|}{$\begin{array}{l}\text { WEST VIRGINIA STATEW } \\
\text { Sample Identification label }\end{array}$} \\
\hline Sampler's Name & Species & mon Name & $\overline{\text { Composite \# }(1,2, \text { or } 3)}$ \\
\hline Total length (mm) & $\begin{array}{l}\text { Predator or } \\
\text { Bottom-dweller }\end{array}$ & \multicolumn{2}{|c|}{$\overline{\text { Sampling site [name and ID (i.e. river mile)] }}$} \\
\hline$\overline{\text { Indiv. Fish \# (1-6) }}$ & Sampling & $(\mathrm{mm} / \mathrm{dd} / \mathrm{y}$ & $\overline{\text { Sampling time (military) }}$ \\
\hline
\end{tabular}


Firgure 3. Chain-of-Custody Forms will accompany each shipment of samples back to WVU and will contain sample identity (coinciding with information on the Field Record Form), sampler relinquishment data and time, and arrival at WVU laboratory data and time. All Chain-of-Custody Labels will be attached to each composite sample following packing in the field, and will include the signature of the sampler and date and time sealed. If a WVU technician is not at the sampling site, arrangements will be made prior to sampling for WVU to pick up the samples.

Chain-of-Custody Label (Completed for each composite sample and placed in bag) WEST VIRGINIA STATEWIDE CONTAMIANT STUDY Chain-of-Custody Label

Sampler's Name and Phone number

$\overline{\text { Sampling Site [name and ID (river mile)] }}$

Species

$\overline{\text { Composite number }}$
Sampler's Signature

$\overline{\text { Sampling Date (mm/dd/yy) Time (military) }}$

$\overline{\text { Number of indiv. fish in composite }}$

Comments: 


\section{Figure 4.}

Chain-of-Custody Form (completed for each shipping container)

WEST VIRGINIA STATEWIDE CONTAMINANT STUDY

Chain-of-Custody Form

$\overline{\text { Sampler's Name and Phone number }}$

Sampling Date $(\mathrm{mm} / \mathrm{dd} / \mathrm{yy})$

Composite Number of Species

Number

\section{Sampler's Signature}

Container of

$\begin{array}{ll}\text { Sampling } & \text { Sampling Comments }\end{array}$
time Site

\section{Delivery Shipment Record}

Relinquished by (name \& signature)

Received by (name \& signature)

Received in WVU lab by (name \& signature)
Date

Date

Date
Time

Time

Time

Remarks 


\section{Standard Operating Procedure WV Statewide Contaminant Study}

\section{Scope and Applicability}

This Standard Operating Procedure (SOP) must be followed by all field sampling collection teams involved with the West Virginia Statewide Contaminant Study. Adherence to the SOP will ensure that field sampling activities will be performed the same way every time.

Fish tissue sample collection procedures are presented as sequential steps in this SOP to follow, and include specific equipment, materials and methods required to perform field sample activities.

\section{Equipment/Materials}

Sampling vessel - OPTIONAL (including boat, motor, trailer, oars, gas and all required safety gear)

Electrofishing equipment - OPTIONAL (including electrofishing boats and backpack electrofishing units, dip nets, protective gloves and boots, and all necessary safety equipment)

Nets - OPTIONAL (including trawls, seines, gill nets, fyke nets, trammel nets, hoop nets, pound lines, trap nets)

Angling Equipment - OPTIONAL (including fishing rods, reels, line, terminal tackle, trot lines, bait)

USGS approved personal floatation devices

Maps of target watersheds

Global Positioning System (GPS) unit - OPTIONAL

Livewell and/or buckets

Measuring board (millimeter scale)

Ice chests

Heavy-duty aluminum foil

Plastic zip-lock bags, large and small 
Plastic bags

Knife and/or scissors

Disposable gloves

Field Record Forms

Sample Identification Labels

Chain-of-Custody Forms

Chain-of-Custody Labels

Scientific collection permit

Ice

Pens and pencils

Clipboard

Packing tape

First aid kit and emergency phone numbers

\section{Procedures:}

1. identify the target watershed to be sampled and select location

2. assemble gear used for fish collection (type of gear at discretion of senior fishery biologist

3. as soon as fish have been collected, they must be identified to species. Disposable gloves should be worn during the handling process. Fish are rinsed in ambient water to remove any foreign material from fish and placed in holding containers (e.g., livewells or buckets). Non-target species are returned to the water.

4. Three predator and three bottom-dweller species composite (each composite containing 6 fish) will be collected from each target watershed. Select fish for each composite based on the following criteria:

5.

a. All are of the same species

b. All satisfy legal requirements of harvestable size (or weight) or at least is of consumable size.

c. All are of similar size, so that the smallest fish in a composite is no less than $75 \%$ of the total length of the largest fish, and 
d. All are collected at the same time (or collected as close to the same time as possible, but no more than one week apart Note: individual fish may have to be frozen until all fish to be included in the composite are available).

Accurate taxonomic identification is essential in assuring and defining the fish that have been composited and submitted for analysis.

6. Following selection of six fish for each of the three composites that meet the above listed criteria for compositing, measure each fish to determine total body length (mm).

7. Record information on Field Record Form.

8. Once a composite has been determined, remove each fish from the bucket and dispatch with a piece of PVC pipe.

9. Wrap each fish in heavy-duty aluminum foil and place Sample Identification Label (that is filled out) in the foil with the fish (label will be composed of "rite in the rain" paper). Make sure information on the Sample Identification Label matches with the Field Record Form. Place fish in zip-lock bag.

10. Place all foil wrapped fish for one composite in large plastic bag. Seal and attach Chain-of-Custody label (that is filled out). Make sure information matches Sample Identification Label and Field Record Form.

11. Place composite on ice in ice chest.

12. Complete a Chain-of-Custody form for each ice chest.

13. Samples must be delivered to WVU within 24 hours or placed on ice within 24 hours of collection and WVU will arrange pickup. 


\section{Appendix II}

For Laboratory Analysis Activities for Statewide Fish Tissue Sampling 
Quality Assurance Project Plan

Prepared for:

Jeff Bigler, Work Assignment Manager

U.S. EPA, Office of Science and Technology

Washington, DC 20460

Prepared by:

Patricia M. Mazik, PhD

USGS/BRD

West Virginia Cooperative Fish \& Wildlife Research Unit

West Virginia University

322 Percival Hall

Morgantown, WV 26506-6125

April 17, 2002

Revision 1

This quality assurance project plan (QAPP) has been prepared according to guidance provided in the document EPA Requirement for Quality Assurance Project Plans for Environmental Data Operations (EPA QA/R-5, USEPA, Quality Assurance Division, Washington, DC, External Review Draft Final, October 1998) to ensure that environmental and quality required for their intended use. The work conducted by the WVU Project Manager will be in conformance with the quality assurance program described in the quality management plan for WVU and with the procedures detailed in the QAPP. 
Table of Contents Appendix II

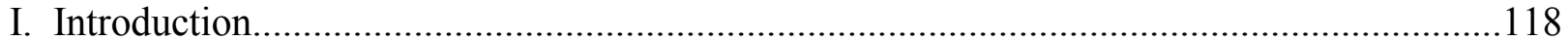

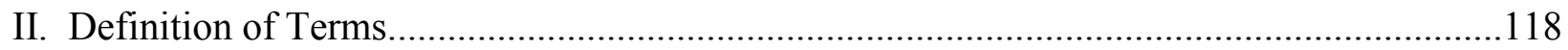

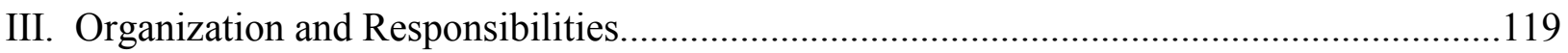

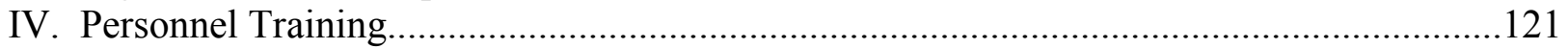

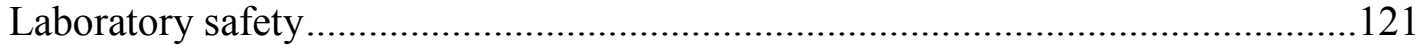

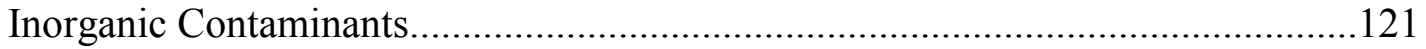

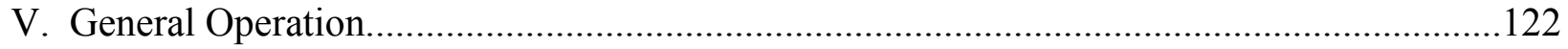

Sample Log In and Sample Handling Procedures..................................................122

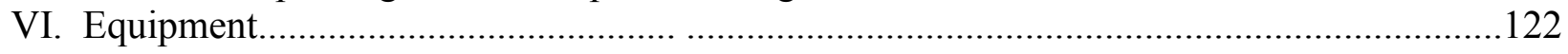

Calibration and Preventative Maintenance.....................................................................122

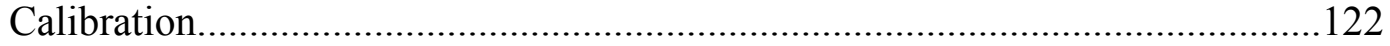

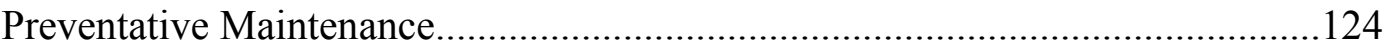

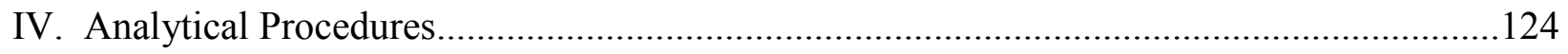

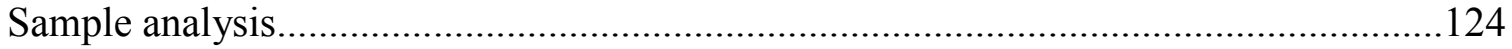

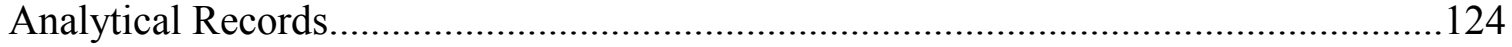

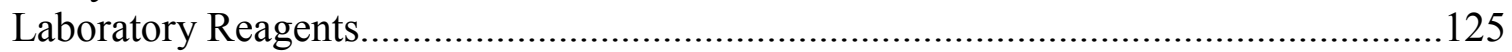

Analytical Method Validations..................................................................................126

Method Detection Limits Explained............................................................................127

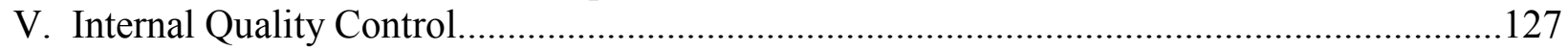

Quality Control Checks............................................................................................127

Performance and System Audits....................................................................................129

Specific Procedures used to Assess Data Quality and Determining Reporting Limits...130

Control Chart Preparation..............................................................................................131

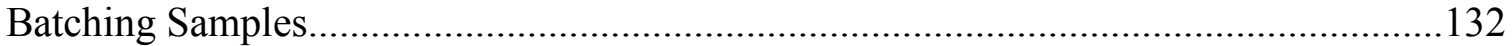

Corrective Actions..........................................................................................132

Quality Assurance Reports......................................................................................133

XI. Data Reduction, Validation and Reporting.....................................................................134

Numerical Data and Calculations..........................................................................134

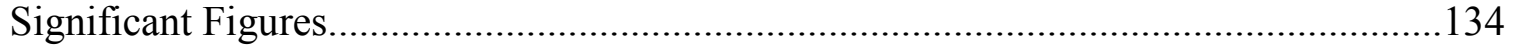

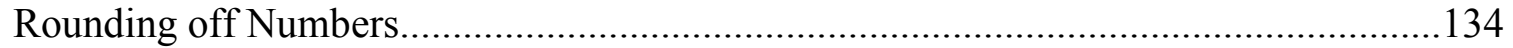

Rounding off Arithmethic Operations...................................................................135

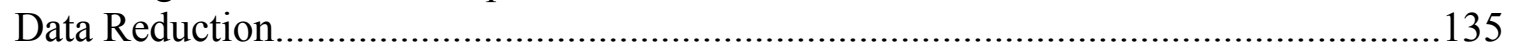

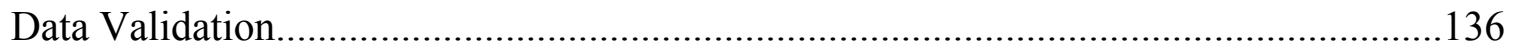

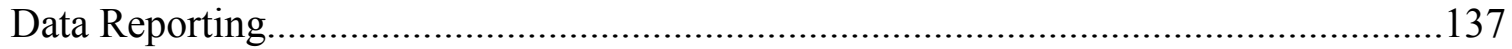

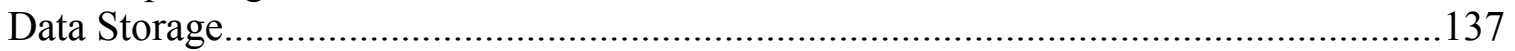

X. Procedures for Handling Technical Complaints...............................................................137 


\section{Introduction}

This document contains the quality assurance plan used by the Analytical Laboratory of the National Research Center for Coal and Energy (NRCCE). The purpose of this plan is assure that data of the highest quality is being reported by the NRCCE Analytical Laboratory. The plan includes quality assurance / quality control (QA/QC) requirements based on EPA guidelines for the analysis of inorganic contaminants. It contains the guidelines required to assure accuracy, precision, completeness, representativeness, and comparability on all tests performed.

NRCCE defines Quality Control as the development, implementation and maintenance of standard operating procedures (SOP's) and of good laboratory practices (GLP's). The QC program also addresses the means of acquiring immediate information about analytical performance, defining acceptable performance, and describing actions to be taken when unacceptable performance occurs.

Authority and responsibility for the operation of this QA/QC plan is a part of this document. All supervisory personnel must read and be fully aware of their duties and responsibilities under the plan.

The QA/QC policies and procedures described herein are designed to reduce or eliminate errors in the sample collecting, testing and data reporting programs. We realize that no QA/QC Program, no matter how elaborate, can eliminate all errors, which may occur during an analysis. For this reason, the program also addresses procedures for correcting those errors, which do occasionally occur.

This QA/QC Program Plan has been modeled along EPA guidelines outlined in "Interim Guidelines and Specifications for Preparing Quality Assurance Program Plans", QAMS-004/80 and "Interim Guidelines and Specifications for Preparing Quality Assurance and modeled after the "Office of Water Resources Division Of Environmental Protection Bureau of Environment, Elkins Laboratory Quality Assurance/Quality Control Program Plan”.

\section{Definition of Terms}

Quality Assurance - analytical protocol used to detect and correct problems in the measurement process or to demonstrate the attainment of a specific statistical control. The objective of a quality assurance program is to reduce the measurement errors to agreed-upon limits and to produce results of acceptable quality.

Quality Control - planned activities designed to produce acceptable results. The quality control program includes the following: Development of and strict adherence to principles of good laboratory practice. Consistent use of standard operation procedures. Establishment of and adherence to carefully designed protocols for specific measurement programs. The consistent use of qualified personnel. Reliable and well maintained equipment. Appropriate calibrations and standards. 
Quality Assessment - techniques used to appraise the quality of the measurement process and the results. Quality assessment procedures include the following: Internal performance audits - conducted by the use of control samples, replicate measurements, spike recoveries, duplicate samples, blank measurements, and the measurement of known standards. External performance audits - conducted by the use of inter-laboratory checks such as: Participation in laboratory evaluation programs (USGS round-robin evaluation). Participation in performance evaluation samples (NPDES).

Data Quality - totality of features and characteristics of data that bear on their ability to satisfy a given purpose. Important parameters include the following: Accuracy - the degree of the difference between the measured value and the true value. Precision - the reproducibility or degree of agreement among replicate measurements of the same quantity. Completeness - the percentage of valid data obtained from a measurement system. Representativeness - the degree to which the data accurately represent a characteristic of a population, parameter variations at a sampling point, a process condition, or an environmental condition. Comparability - the confidence with which one data set can be compared to another.

Standard Operating Procedure (SOP): A detailed, written description of a procedure designed to systematize and standardize the performance of the procedure.

Holding Time: The period of time during which a sample can be stored after collection and preservation without significantly affecting the accuracy of the analysis.

Sample Delivery Acceptance: The point in time at which the laboratory representative determines that it can proceed with the analytical work. Sample delivery acceptance follows receipt and inspection of the samples and complete definition of analyses required.

Completeness: A measure of the amount of valid data obtained from a measurement system compared with the amount that was expected to be obtained. In order to be considered complete, the data set must contain all QC check analyses verifying Precision and Accuracy for the analytical method.

Comparability: Expression of confidence with which one data set can be compared to another data set measuring the same analyte. Comparability can be ensured through the use established and reporting.

\section{Organization and Responsibility}

The NRCCE is located along Evansdale Drive on the Evansdale campus of West Virginia University, Morgantown, WV

Laboratory Director (Mr. David L. Brant)- the laboratory director is responsible for the technical quality, cost control, laboratory personnel management, and adherence to project schedules. His overall management involves the quality assurance of the following items: delivery order/work assignments, adherence to delivery schedules, deliverable reports, 
subcontractor work, project/contract cost control and accounting, task performance of key personnel.

Section Head (Mr. David L. Brant)- the section head oversees the primary functions of his group: sample control, document control, data management, and client services. The section head provides supervision and guidelines for sample handling and storage prior to analysis, maintenance of project files, data entries into the computer system after analysis, and quality review of the final data delivered.

Analyst (Mr. Ken Stewart)- the analyst operates the instruments that he has demonstrated an ability to use with minimal supervision. The analyst is also responsible for initial data validation to determine if a set of samples should be re-analyzed or if they have met acceptable QC requirements.

The USEPA Project Manager is Jeff Bigler who will supervise the project for USEPA.

The WVU Project Manager is Dr. Patricia Mazik, who will supervise the assigned project personnel to provide for their efficient utilization by directing their efforts either directly or indirectly. As Project Manager she will have the following responsibilities:

provides oversight for study design, sample collection and adherence to design objectives,

reviewing and approving the project work plan, QAPP, and other materials developed to support the project,

coordinating project assignments in establishing priorities and scheduling,

ensuring completion of high-quality projects within established budgets and time schedules,

providing guidance, technical advice and performance evaluations to those assigned to the project,

implementing corrective actions and providing professional advice to staff, and

preparing and/or reviewing preparation of project deliverables.

The DEP Project Manager/QA Officer is Janice Smithson, who will be responsible for overseeing the project and also serving as Quality Assurance Office. In this position, she will be responsible reviewing and approving all Quality Assurance Project Plans (QAPP). Additional responsibilities include the following:

Conducting external performance and system audits of the procedures

Monitoring quality control (QC) activities to determine conformance 
Reviewing QAPP for completeness and noting inconsistencies

Providing support to USEPA and WVU Project Manager in preparation of the work plan and QAPP and in their distribution, and

Approving the QAPP.

\section{Personal Training}

All positions involve on-the-job training. This training requires the reading of our methods manual and satisfactory performance of the method under the supervision of the Section Head. The employee must also read and demonstrate an understanding of the QA/QC manual and the health and safety documents.

\section{Laboratory safety}

The NRCCE Analytical Laboratory is committed to safe operations within the laboratory and evaluates all samples received with respect to the potential hazard involved. All samples received are considered to be potentially hazardous and are handled accordingly.

Essential points of the safety program include:

Basic laboratory orientation and safety training for all new employees on the first day of work: Hazard communication training; includes using and interpreting Material Safety Data Sheets (MSDS); Response procedure to laboratory emergencies. Adequate fire precautions shall be taken, including, but not limited to having readily available a fire extinguisher rated for this type of fires that may reasonably be foreseen. While specific safety criteria are not an aspect of laboratory certification, laboratory personnel should apply general and customary safety practices as a part of good laboratory procedures. Each laboratory is strongly encouraged to have a safety plan as part of their standard operating procedure. Where safety practices are included in an approved method, they must be strictly followed.

\section{Inorganic Contaminants}

Glassware preparation: Only Class A volumetric glassware is used by the laboratory for measuring during both inorganic and organic analyses. Glassware is washed in a warm detergent solution and thoroughly rinsed with tap water followed by soaking in a bath of $1: 1 \mathrm{HNO}_{3}$ overnight followed by soaking in a water bath overnight and rinsed 3 times with deionized water. This cleaning procedure is sufficient for general analytical needs, but the individual procedures must be referred to for precautions to be taken against contamination of glassware. It is advantageous to maintain separate sets of suitably prepared glassware for the nitrate, mercury, and lead procedures due to the potential for contamination from the laboratory environment. 
required. Currently the NRCCE Analytical laboratory is utilizing an ASTM Type 1 water system for use in the laboratory for dilution, preparation of reagent solutions and final rinsing of glassware. The water system is free from contaminants. Quality checks must be made at planned intervals and documented.

Compressed air: Compressed air is employed mainly in the Atomic Absorption instrument as an oxidizing agent, and in the Ion Chromatograph to drive the auto sampler.

Hood system: The hood system used contains two Class II Laminar flow hoods located in Rooms G28 and G29. Room 130 contains a perchloric acid hood with a wash down system on both hood and stack. The remainders of the labs have "intelligent" hoods that adjust airflow as panels are opened. The laboratory fume hood face velocity is calibrated every four months for optimum face velocity.

Smoking is strictly forbidden in the laboratory or the office (as with all University housed operations) and the temperature is closely controlled. The laboratory has ventilation equipment to remove fumes and vapors from the work area.

\section{General Operation}

\section{Sample Log In and Sample Handling Procedures}

The samples are logged in by the Lab Analyst, who is responsible for all aspects of initial sample log in. Sample log-in is one of the most decisive elements in the lab QA/QC plan. Accurate logging helps prevent later analysis error such as, omitting a parameter form the testing routine or adding an unnecessary parameter to the testing routine that wastes valuable time. Great care is taken to be certain the lab number applied to the sample container is correct, an error here is very difficult to correct later. This log in number is used on each Sample Quality Control Form for every parameter analyzed on the sample. Parameters to be analyzed are PCBs and mercury.

As a matter of policy, the Field Record Form must accompany all samples accepted by the laboratory. The Field Record Form stays with the original paperwork of testing the samples.

When the samples have been distributed to the appropriate storage refrigerator, the Lab Analyst generates Sample Quality Control Forms for each parameter needed to be analyzed. These Sample Quality Control Forms are marked with the sample's log-in number. The log-in number along with the sample source, date collected and received, and parameters requested are place in the log book.

\section{Equipment}

\section{Calibration and Preventative Maintenance}

\section{Calibration}


All instruments are calibrated according to the specific analytical methodology. This laboratory follows the calibration techniques given in EPA's 40CFRI36 "Guidelines Establishing Test Procedures for the Analysis of Pollutants Under the Clean Water Act", July 1, 1991, etc. seq. Either external standards or internal standard methodology is used. Other instruments used in the laboratory such as incubators, ovens, refrigerators, thermometers, etc. are calibrated according to manufacturers recommendation or laboratory general accepted practices. All instrumentation and equipment used in the laboratory is supplied with QC Calibration and Mmaintenance sheets, where daily calibrations, annual calibration checks, routine maintenance, and repairs are recorded. The immediate calibration sheets remain with the instrument while past calibrations are filed; maintenance sheet are filed in the instrument's or the equipment's file.

At minimum, each QC Calibration and Maintenance sheet documents:

Each time the instrument is taken out of service and the type of repair made.

Each time the instrument is moved to a new location.

Each time the instrument receives routine maintenance from either DEP staff or instrument company representative.

Any abnormal behavior observed in the instrument, even though it does not affect the quality of results.

Each entry is dated and initialed by the person making the entry. These entries are reviewed periodically by the Laboratory Director.

Calibration Schedule

Atomic Absorption Spectrophotometer - standard Absorption is measured on acidified stock solutions - Daily

Balances - N-BS Certified Weights - Daily

Computer Aided Titration pH Meter - Standard Buffers - Daily

Conductivity Meter - Standard KCI Solution - Daily

Ovens - Calibrated thermometer - Monthly

pH Meter - Standard Buffers - Each time used.

Refrigerator - Certified Thermometer - Daily

Spectrophotometer - Standard solutions - Daily

Thermometers - NBS Certified Thermometer - semi-annually

ICP - Standard Solutions - Daily

Ion Chromatograph - Standard Solutions - Daily 
ICP-MS - Standard Solutions-Daily

GC's -Standard Solutions- Daily

\section{Preventative Maintenance}

Regular inspection, cleaning and, servicing of all equipment is performed according to manufacturer's recommendations. Maintenance records are kept indicating maintenance /repair dates, problems and steps taken to correct these problems. In-house personnel perform routine repairs and maintenance.

Suspended Solids - Precision checks are run on every 5 samples. Accuracy of method is checked with spikes every 10 samples.

Refrigerator - Temperature checked daily with traceable thermometer.

Trip \& Field blanks - To assure QC in the field, trip \& field blanks will be taken during each sampling trip.

Duplicate Samples - To assure QC in the field \& in the tab, duplicate samples will be tested four times a year.

Lab Pure Water - The distillation apparatus is periodically cleaned to remove sediment. Deionizer cartridges dated \& changed when exhausted. Produced water tested monthly for $\mathrm{pH}$, chlorine, conductivity, \& metals and annually for bacterial contamination.

Stock Solutions - Stock solutions dated when received \& also upon opening. Concentrations of stock solutions verified $\&$ recorded before use. Stock solutions stored according to manufacturer's directions. Stock solutions are disposed of when out-of-date.

\section{Analytical Procedures}

\section{Sample Analysis}

Mercury and PCBs will be analyzed on fish tissue. Mercury will be analyzed using EPA method 245.6. PCBs will be extracted using EPA procedure 3545. PCBs will be analyzed using EPA method 8250A.

\section{Analytical Records}

An analysis Sample Quality Control Form must be used for each test sample wherein each analytical measurement can be documented. All measurements must be recorded, even those used to assess instrument condition or to screen sample prior to actual analysis. This documentation must be easily retrievable. 
All instrument calibrations must be documented on the instrument calibration and Maintenance Sheet as previously described.

All entries on the Sample Quality Control Form and Instrument Calibration and Maintenance Sheet must be dated and initialed. If corrections must be made, the original entry should be struck through with a single line and the new entry made. Erasure or "white-out" is not permitted.

Raw test data is recorded, in ink, on laboratory worksheets by each operator. These worksheets are on permanent file \& can be rechecked.

Data reduction is handled by the computer \& backed-up daily.

The computer results are then recorded, in ink, onto the original worksheet $\&$ revalidated.

A client's final report is typed in duplicate \& mailed at frequencies specified by the client (daily, weekly, monthly).

Clients are informed of their results by phone, immediately upon test completion, if requested.

Final reports will be kept on permanent file. Records of chemical analyses are to be kept by the laboratory for a minimum of 3 years. This includes all raw data, calculations, and quality control data. These data files may be either manual or computer based. The following information may be available as a sample data report or summary record:

Date, place, time of sampling, preservative added and name of person who collected the sample.

\section{Laboratory Reagents}

Chemicals/reagents: "Analytical reagent grade "(AR) chemicals must be used for most analyses required of water treatment laboratories, however, certain analytical procedures may require special reagents. Consult Standard Methods for the Examination of Water and Wastewater, $16^{\text {th }}$ ed., part $102 \mathrm{pp}$. 4-6 for more detailed information on reagent grades. Individual analytical methods in the approved reference may specify additional requirements for the reagents.

Primary standards and/or stock standards are obtained form a reliable certifiable source and are of high purity. Standards are purchased from approved commercial vendors such as Aldrich and Fisher Scientific for use in all analytical testing. The standards are protected from degradation deterioration, and contamination based upon storage requirements (i.e. polyethylene containers for alkali solutions, glass containers for organic: and brown glass containers for light sensitive solutions; temperature storage and segregation based on reactivity).

Stock and working standards solutions are prepared fresh as required by their stability, and are checked regularly for degradation (i.e. discoloration formation of precipitates). Standard solutions are labeled with compound (name, concentration, date prepared, and preparer's initials. 


\section{Analytical Method Validations}

This section describes the minimum steps to be taken to ensure that an analytical test method is valid. A method is considered to be valid if:

It actually measures the parameter in question.

It actually quantifies the parameter.

It has known limits of detection and precision, At the issuance of this plan, all methods should be reevaluated

The results of these validation studies, which will take the form of a series of precision and accuracy studies, will be used to determine if the method is valid. Once this initial study is completed the following conditions will cause a new study to be performed:

A new analyst begins performing the test;

A new instrument is to be used in performing the test;

A new method is introduced. If the new method is to replace a currently used method, the new method must achieve a performance within the accuracy and precision limits of the original test method.

Many test methods have accuracy and precision statements published with them. In these cases laboratory precision and accuracy data must be equal to or better than the published data before the method can be used.

It is the responsibility of the Lab Analyst to ensure that all validation steps are carried out on each method and that the data is reported accurately to the Laboratory Director. It is the responsibility of the Laboratory Director to prepare the accuracy and precision statement for each method.

The following steps should be taken to validate a test method for a specific analyte:

All tests must be run in duplicate to determine precision;

Use laboratory pure water as the matrix;

A single analyst who uses a test method must analyze a minimum of seven performance spikes. If more than one analyst uses the method, then each must analyze the seven spikes individually;

The spikes should be prepared by the analyst using the method because they will be the one spiking the actual samples in the future if the method is valid;

The source of the spiking mater and how the spikes are prepared should be documented in the QC File;

The concentration of the performance spikes should be in the range of two to four times the method detection limit;

A blank must be prepared and ran along with the spikes.

The Laboratory Analyst will use the data generated to report the following information: 
Mean Recovery (R) and Standard Deviation (SD)

Confidence Interval (CI) using the formula:

$$
\mathrm{CI}=\mathrm{R} \pm \frac{\mathrm{t}(\mathrm{SD})}{\sqrt{n}} \quad \begin{aligned}
& \text { Where: } \mathrm{t}=\text { "Student } \mathrm{t} \text { Value" for a } \\
& \text { one-tailed test at } 99 \% \text { confidence } \\
& \text { and } \mathrm{n}-\mathrm{I} \text { degrees of freedom }
\end{aligned}
$$

The Method Detection Limit is calculated by:

Where: $\mathrm{t}=$ "Student $\mathrm{t}$ Value" for a one-tailed test at 99\% confidence and $\mathrm{n}$-I degrees o freedom

$$
\begin{array}{ll}
\text { MDL }=\mathrm{t}(\mathrm{SD}) \quad & \text { Where: } \mathrm{t}=\text { "Student } \mathrm{t} \text { Value" for a } \\
& \text { one-tailed test at } 99 \% \text { confidence and } \\
& \mathrm{n}-\mathrm{I} \text { degrees of freedom }
\end{array}
$$

\section{Method Detection Limits Explained}

There have been many terms used to designate detection limits: Lower Limit of Detection (LLD); Minimum Detection Amount (MDA); Limit of Detection (LOD) and Detection Sensitivity (DS). We use the term Method Detection Limit (MDL).

DEP laboratories have established and periodically reevaluate their MDL's for each sample and matrix type for each measurement method used. For one time only matrix and/or analyte, this is not done because it is impractical. The MDL is determined for each measurement system by the analysis of at least seven (7) replicates of spiked matrix samples*. The assessment of the MDL is based upon the performance of the entire measurement system.

*While Method Detection Limits are obtained from analysis of reagent water standard as specified in 40CFRI36, actual detection limits for an environmental sample are matrix dependent and may be higher than the MDL.

\section{Internal Quality Control}

\section{Quality Control Checks}

The effectiveness of a QA Program is measured by the quality of data generated by the laboratory. Data quality is judged in terms of its Precision, Accuracy, Representative ness, Completeness, and Comparability.

This laboratory monitors data quality with internal QC checks.

These checks are of three types:

Duplicate sample tests to determine Precision; >Sample spiking to determine Accuracy;

Testing external standards to determine Accuracy as well as method applicability.

Performance and System Audits are conducted in the laboratory on a routine basis. Several different types of audits are performed: 
Performance Evaluation Samples for EPA, WP Series are tested twice per year; System Audits by the QAPL are conducted several times per year with no prescribed frequency and without prior notice.

These internal QC checks are used to answer two questions:

1. Are laboratory operations "in control" during data generation?

2. What effect does the sample matrix have on the data being generated?

The first question is answered by Laboratory Performance QC which is based on the use of standard samples prepared in a control matrix to generate Precision and Accuracy data.

The second question is answered with matrix-specific QC which is based on the use of actual environmental samples to generate Precision and Accuracy data. Matrix Duplicates and Matrix Spikes are analyzed to generate the required data. This information, in conjunction with the method blank, is used to assess daily laboratory performance.

The Matrix Duplicate and Matrix Spike are tested at a rate of 5\% for all inorganic methods where the procedures are applicable except metals where a 10\% frequency is used. One duplicate and spike for every 10 samples.

Laboratory Control Samples (LCS) are primary standards generated by the laboratory and used to monitor the day-to-day performance of routine analytical methods. Certain standards are used to monitor the Precision and Accuracy of the analytical process as well as to calibrate any instruments used in the analysis.

The use of LCS offers the advantage of being able to differentiate low recoveries due to procedural errors from those due to matrix effects. As a result, procedural errors can be identified and corrected by the analyst at the bench, without waiting for extensive review. This will also eliminate costly and time- consuming reanalysis of the sample.

Matrix Duplicate (MD) is an environmental sample which is divided into two separate aliquots. These aliquots are tested identically the same as the other samples in the analysis run and their results compared to determine the precision of the test run. The sample range is determined in the acceptability of the data for which the run is determined.

A Matrix Spike (MS) is an environmental sample to which known concentrations of analytes have been added. The MS is taken through the entire analytical process and the recovery of the analyte is calculated. Results are expressed as percent recovery. The MS is used to determine the Accuracy of the data generated for the sample "run". The Shewhart Method is used to determine the acceptability of the data.

If either the Precision data or the Accuracy data falls beyond the control limits as determined by the Shewhart Method all samples tested from the last acceptable P\&A test must be reanalyzed. Another P\&A failure will require a complete evaluation of the method, 
instruments and reagents to determine the reason for the failure. Once the problem has been identified and corrected, the samples are reanalyzed as before using a new MD and MS sample.

Method Blanks (MB) [reagent blanks] are analyzed to determine the level of background interference or contamination, which exists in the analytical system which might lead to reporting elevated concentration levels.

A Method Blank is analyzed with every batch of samples processed. The Method Blank consists of the reagents specific to the method which are carried through every step of the analytical procedure. The results of the MB analysis are evaluated to determine the acceptability of the data generated for that batch of samples.

Ideally, the concentration of target analytes in the MB will be below the minimum detection limit for the analyte. Some common laboratory solvents and metals are difficult to eliminate to the levels commonly reported. Therefore, blank acceptability is based on analytical techniques, analytes reported and Reporting Limits required for the samples being tested.

For metals, the Reporting Limits are typically near the detection limit and background levels for certain metals are difficult to eliminate. In this case, Laboratory Policy is that the concentration of the target analyte in the MB must be below two the Reporting Limit. If the concentration of the target analyte is greater than two times the Reporting Limit, then the target analyte concentration must be greater than ten times the blank concentration.

Generally speaking, the MB is used both to zero the equipment and as one of the calibration standards. If a preparation step is required for the analysis, then the blank is carried through this preparation step also, in order to determine the extent of contamination or interference picked up in the preparation step. In most cases, the concentration found in the MB is subtracted from the concentration of the target analyte in the sample prior to calculating the final result.

If the MB does not meet acceptable criteria limits, the source of contamination must be located and corrective action taken.

Field Blanks (FB) are check samples that monitor contamination originating from the collection, transport or storage of environmental samples. The results from FB's are reported in the same concentration units as the samples. No correction of the analytical data is done based on the analysis of FB's. This laboratory uses only one basic type of Field Blank:

Equipment Blank is blank water that is poured through the sample collection device to check for adequacy of cleaning. Where a collection device is not used, the blank water is poured into another container to check for contamination picked up in transporting the sample container to the sample site. Equipment Blanks are collected by the DEP Monitoring Group with each set of samples submitted for analysis.

\section{Performance and System Audits}

A Performance Audit verifies the ability of the laboratory to correctly identify and quantify compounds in blind check samples submitted to the laboratory by the US-EPA. The purpose of these EPA Audits is to identify those laboratories that are capable of generating 
reliable data and put those laboratories who fail on notice of the need for remedial action.

A system Audit is a review of laboratory operations conducted to verify that the laboratory has the necessary equipment, staff and procedures in place to generate acceptable data.

The results of the Performance and system Audits are used to identify areas where additional training is needed, clarification of procedures is required or additional equipment is needed.

\section{Specific Procedures used to Assess Data Quality and Determine Reporting Limits}

Precision and Accuracy control charts are prepared in accordance with EPA Manual 600/4-79-019 "Analytical Quality Control in Water and Wastewater Laboratories" using the Shewhart Method for calculating the Control Limits. A minimum of 25 sample tests shall be used in calculating the Precision and Accuracy Control Limits. One control chart shall be prepared for each target analyte (where applicable) and for each analyst.

The results of the Performance and System Audits are used to identify areas where additional training is needed, clarification of procedures is required or additional equipment is needed.

"Analytical Quality Control in Water and Wastewater Laboratories" using the Shewhart Method for calculating the Control Limits. A minimum of 25 sample tests shall be used in calculating the Precision and Accuracy Control Limits. One control chart shall be prepared for each target analyte (where applicable) and for each analyst.

Precision shall be calculated from 25 duplicate samples using the following formulas:

Upper Warning Limit, UWL $=2.51 \mathrm{X} \mathrm{R}$

Upper Control Limit, UCL $=3.27$ X R

Where $\mathrm{R}$ is the difference between the observed values for the Matrix Duplicates divided by the number of Matrix Duplicates tested.

Accuracy shall be calculated from 25 spiked samples using the following formulas:

Percent Recovery, $\mathrm{P}=\frac{\mathrm{a}-\mathrm{b}}{\mathrm{c}} \times 100$

Where: $\mathrm{a}=$ Observed spiked sample calculation

$\mathrm{b}=$ Observed unspiked sample calculation

$\mathrm{c}=$ Concentration of spike added to the sample

Standard Deviation, $S D=\sum \mathrm{p}^{2}-\frac{\left(\sum \mathrm{p}\right)^{2}}{\mathrm{n}}$ 
Where: $\mathrm{P}=$ Percent Recovery

$\mathrm{n}=$ Number of Sample Used in the Calculations

Accuracy Control Limits Calculations:

Upper Control Limit, UCL $=\mathrm{P}+3 \mathrm{SD}$

Upper Warning Limit, UWL $=\mathrm{P}+2 \mathrm{SD}$

Lower Warning Limit, LWL $=$ P - 2 SD

Lower Control Limit, LCL $=$ P - 3 SD

Where $\mathrm{P}$ is the average of the $\mathrm{P}$ values calculated

From the above data a Control Chart may be generated. Daily Observations must fall within the Control Limits established from these calculations. Any QC sample that falls beyond the upper or lower Control Limits is considered out of control and must be reanalyzed.

The Control Chart allows the analyst to determine which data points (representing QC measuring events) are part of an out-of-control population and therefore indicative of possible problems in the population and therefore indicative of possible problems in the analytical system. This procedure allows for differentiation between normal variation inherent in any measurement process and that variation attributable to a process moving away from normal.

The Control Chart is particularly useful in uncovering "trending". Trending is the characteristic of data to cluster on one side or the other of the mean or show greater separation from the mean when changes are occurring in the process.

This same information can be obtained from the QC data, but is more pronounced when presented on a chart. When data begins to separate from the mean over a period of time and this separation is generally getting further away from the mean, it indicates to the analyst that measurement conditions may be changing and investigation of the system is warranted. This trending is best uncovered by a control chart.

\section{Control Chart Preparation}

The axes on the Control Chart

$\mathrm{X}=$ Time. Each segment represents a single event or one QC test.

$\mathrm{Y}=$ Units of the control measure being made.

The Mean (M) Line is the value of the mean of the control measurements extended across the chart parallel to the $\mathrm{X}$-axis. The degree of deviation from this line is used to determine the state of control of the measurements.

Control Limit Lines are a function of the standard deviation of the control measurements. These are represented as lines drawn parallel to the $\mathrm{X}$-axis and placed at $\mathrm{X}=\mathrm{k} \mathrm{SD}$; where $\mathrm{k}$ is a 
constant derived from various probability functions. In this formula, a "+" value represents an Upper Control Limit while a “_“"value represents a Lower Control Limit.

These Control Limits have varying degrees of importance depending on the type of chart used: Precision Charts are generated from the percent relative difference between duplicate measurements and normally used, use only the Upper Control Limits. Since high Precision is represented by values approaching zero, and differences are calculated in absolute terms, only measurements moving away from zero need to be controlled;

Accuracy Charts are generated from percent spike recovery data and use both Upper and Lower Control Limits. Since high accuracy is represented by $100 \%$ recovery of the spike, deviation from this value in both directions must be controlled.

An analytical system is considered to be out of control if a QC measurement exceeds the Control Limit established for the analyte and the analysis method. In setting the control limits where they are not predetermined, the value 3.27 is used for Precision and 3 SD is used for Accuracy.

\section{Batching Samples}

Batching is the way in which groups samples are assigned to specific QC measurements. Most methods require 5 to 10 percent of the sample be subjected to QC testing depending on the parameters measured and the degree of control required. As a minimum, each batch of samples tested will have one blank and one control measurement for Precision and Accuracy. If one of these ( $\mathrm{P} \& \mathrm{~A}$ ) control measurements is found to be out of control, all of the samples in the batch are considered to be out of control and must be retested.

\section{Corrective Actions}

Corrective actions are taken when a batch of samples are found to be out of control. When errors or out of control situations exist, the QA Program provides procedures, "Corrective Actions", to resolve the problems.

Corrective Actions are required when:

QC data are outside of acceptable control limits for Precision or Accuracy;

Blanks and/or Standards contain contaminants above acceptable levels;

Spike recoveries are beyond acceptable levels;

Duplicate agreements are beyond acceptable values;

Deficiencies are detected by the QAPL during internal audits

or from the results of Performance Evaluation Sample testing.

Corrective action procedures are usually handled at the bench by the analyst. If the problem persists or cannot be identified, the matter is referred to the Laboratory Director for investigation. Once resolved, the corrective actions are documented in the QC file. 
Each step outlined below is performed to correct a QC problem. If the error is found in a particular step, corrective action ends. If the error is not found the analyst goes to the next step. The following steps are taken to correct an out of control situation:

1 No further analyses are attempted until the problem is corrected and the system is demonstrated to be in control:

2 Check for calculation errors;

3 Check for make-up in errors in the QC sample(s);

4 Reanalyze the QC samples in question. Based upon the judgment and experience of the analyst:

A. A sample preparation or matrix problem exists (go to 7);

B. Instrumentation or process problem exists (go to 8);

5 Perform a calibration check by analyzing one or more freshly made calibration standards. If the calibration check passes, discard the original calibration standards, use the new standards to recalibrate and reanalyze the batch of samples affected.

6 Perform a calibration check by analyzing a standard sample (EPA Performance Sample) or another reference standard made up from primary reagents. If the calibration check standards pass but the standard reference material (SRM) fails; discard the original calibration standards, make up new standards from fresh reagents, recalibrate, reanalyze the SRM. If OK, discard old reagents.

7. If the problem with the environmental sample still exists but the standards are OK, it is a possibility that a matrix or preparation problem exists. Investigate using the following steps:

A. Select a new environmental sample, not of the same matrix (company, stream, etc.) and perform the QC tests. If OK, release the data for all samples not of the problem matrix.

B. Retest the problem matrix beginning with the preparation step. If the QC is $\mathrm{OK}$, report the results and note in the QC file that a problem existed with the preparation or matrix or the original QC sample.

8. An instrument or process problem may exist. If other QC controls are properly functioning, this problem should be identified before analyzing samples. If samples have been analyzed and the problem is identified by a QC measurement, the following steps must be taken;

A. All instrument and process elements must be brought into specifications;

B. All instruments must be recalibrated;

C. The original QC sample should be reanalyzed. If the QC measurement is not in control go to step 7. If the measurement is now in control, all samples in the batch should be reanalyzed. Document your findings as an instrument or process problem in the QC file.

\section{Quality Assurance Reports}

On a quarterly basis the WVU Project Manager will review all QC files. Any deficiencies will be noted and reported to the Laboratory Director. Annually, a Quality 
Assurance Report will be generated. This report will contain a summary of Precision and Accuracy results as well as Corrective Actions taken. Results from all Performance Evaluation Samples will also be summarized.

\section{Data Reduction, Validation and Reporting}

\section{Numerical Data and Calculations}

The NRCCE Analytical Laboratory subscribes to the EPA protocols for handling numerical data and performing calculations.

\section{Significant Figures}

The term significant figure is used rather loosely to describe some judgment of the number of reportable digits in a result. Proper use of significant figures gives an indication of the reliability of the analytical method used. A number is an expression of quantity. A figure or digit is any of the characters $0,1,2,3,4,5,6,7,8,9$ which, alone or in combination, serves to express a number. A significant figure is a digit that denotes the amount of the quantity in the place in which it stands.

Reported values should contain only significant figures. A value is made up of significant figures when it contains all digits known to be true and one last digit in doubt. For example, if a value is reported as $18.8 \mathrm{mg} / \mathrm{L}$, the " 18 " must be a firm value while the " 0.8 " is somewhat uncertain and may be "7" or "9".

The number zero may or may not be a significant figure:

Final zeros after a decimal point are always significant figures. For example, 9.8 grams to the nearest $\mathrm{mg}$ is reported as 9.800 grams.

Zeros before a decimal point with other preceding digits are significant. With no other preceding digit, a zero before the decimal point is not significant.

If there are no digits preceding a decimal point, the zeros after the decimal point, but preceding other digits are not significant. These zeros only indicate the position of the decimal point.

Final zeros in whole number may or may not be significant. In a conductivity measurement of $1000 \mathrm{umos} / \mathrm{cm}$, there is no implication that the conductivity if $1000+1$ umho. Rather, the zeros only indicate the magnitude of the number.

\section{Rounding off Numbers}

Rounding off of numbers is a necessary operation in all analytical areas. It is automatically applied by the limits of measurement of every instrument and all glassware. However, it is often applied in chemical calculations incorrectly by blind rule or prematurely, and in these instances, can seriously affect the final results.

Rounding off should normally be applied only as follows: 
If the figure following those to be retained is less than 5, the figure is dropped and the retained figures are kept unchanged. Example: 11.443 is rounded off to 11.44.

If the figure following those to be retained is greater than 5 , the figure is dropped and the last retained figure is raised by 1. Example: 11.446 is rounded off to 11.45.

When the figure following those to be retained is 5 , and there are no figures other than zeros beyond the 5, the figure is dropped, and the last place figure retained is increased by 1 if it is odd, or it is kept unchanged if it is an even digit. Example: 11.445 is rounded to 11.44 while 11.435 is rounded to 11.44 .

\section{Rounding off Arithmetic Operations}

As has been said earlier, rounding operations can be applied at an inappropriate time in the calculations. The following rules apply to rounding off numbers as they apply to the arithmetic operation to be performed:

Addition: When adding a series of numbers, the sum should be rounded off to the same number of decimal places as the addend with the smallest number of places. The operation of addition is completed with all decimal places intact. Example:

$11.1+11.12+11.13=33.35$.

The sum is rounded to 33.4

Subtraction: When subtracting one number from another, rounding off should be completed before the subtraction operation to avoid invalidation of the whole operation.

Multiplication: When two numbers of unequal digits are to be multiplied, all digits are carried through the operation, then the product is rounded off to the number of significant digits of the less accurate number.

Division: When two numbers of unequal digits are to be divided, the division is carried out on the two numbers using all digits. The quotient is then rounded off to the number of digits of the less accurate of the division or dividend.

\section{Data Reduction}

In order for the data to be reportable, certain methods and procedures must be followed. Notice that the Laboratory Supervisor is responsible for this aspect of the validation process:

The sample must be appropriate to the analysis requested. The Laboratory Director must be notified immediately of any problems (insufficient sample, wrong preservative, wrong type container, etc.)

The sample must be tested within the maximum holding time allowed by EPA. It is the Laboratory Director's responsibility to see that samples are tested in a timely manner. All violated holding times, if the sample is tested, must be noted on the final report form. 
All analytical data generated within the NRCCE Analytical Laboratory are extensively checked for accuracy and completeness. The data validation process consists of data generation, reduction and three levels of review as described below:

Level 1:

The analyst who generates the data has the prime responsibility for the correctness and completeness of the data. All data are generated and reduced following protocols specified in the laboratory SOP Manual. In step I of the review, each analyst reviews his or her work based on an established set of guidelines:

Sample preparation information is correct and complete;

Analysis information is correct and complete;

The appropriate analytical procedures have been followed;

Analytical results are correct and complete;

QC samples and blanks are within established control limits;

Documentation is complete $\mathrm{f}$ or the work done by the reviewing analyst.

Level 2:

The analyst passes the package of the data from the reduction step from Level I which is documented, signed and dated by the analyst to the Laboratory Director for this review step. This review is conducted according to established guidelines to ensure that:

Calibration data are scientifically sound, appropriate to the method and completely documented;

QC samples and blanks are within established control limits;

Qualitative identification of sample components is correct;

Quantitative results are correct;

Documentation is complete and correct;

Data is ready for incorporation into the final report;

Data package is complete and ready to be archived.

\section{Data Validation}

The Level 2 Review is usually conducted simultaneously by the Laboratory Director and the WV Project Manager. After both have reviewed their portions of the data package and have signed off on it, the package is then sent to the DEP Project Manager/QA who has ultimate responsibility for the laboratory data generated and who interfaces with the person or agency generating the samples tested. The review by the DEP Project Manager/QA is the Level 3 Review.

The Level 2 Review is structured so that all calibration data and QC sample results are reviewed and all of the analytical results from $10 \%$ of the samples are checked back to the Sample Quality Control Form. If no problems are found, the review is complete. If any problems are found with the data package, an additional $10 \%$ of the samples are checked back to the 
Sample Quality Control Form. This process continues until no errors are found or until the entire data package has been reviewed.

An important part to the Level 2 Review is the documentation of any errors that have been found and corrected. Errors that are found are documented and transmitted back to the analyst. The cause of the error is addressed with additional training to ensure that quality data will be generated in the future.

Each step of this review process involves evaluation of data quality based upon the results of QC data and the professional judgment of those conducting the review. This evaluation of the data is essential in ensuring that data of high quality are generated consistently.

Each value reported is reviewed in terms of "normal values" for the respective environmental matrix and all available QA/QC data. Outliers or other abnormal values are carefully scrutinized, and samples are reanalyzed if the abnormally cannot be explained. In cases where spiked samples indicate possible interferences, attempts are made to remove the interference. If the problem cannot be resolved, the data is flagged on the report.

\section{Data Reporting}

Analytical data is reported by sample and test. The reference for methodology (analysis code) is reported. The QC date for the sample is retained in the original package unless specifically requested by the sample generator.

The original Field Record form is retained with the original Sample Quality Control Forms, printouts, etc. and a copy of the $\mathrm{C} / \mathrm{C}$ form mailed to the sample generator. In cases where expert testimony is presented in court by the witness. This file is then returned to the laboratory archives for future reference.

\section{Data Storage}

The documents comprising the final report, Sample Quality Control Forms, etc. are filed by sample set or study identification as appropriate. These records are must be kept for at least a minimum of 5 years.

\section{Procedures for Handling Technical Compliants}

1. A Client or Engineering Firm informs lab that an analytical result is questionable.

2. Lab checks the following for errors: data on computer file, data on worksheet, calculations for that test, calibrations, and QC for the test that day.

3. If no error can be found, the Lab will re-run test on newly acquired sample. 
Appendix III

Mercury and PCB Results for Statewide Analysis 


\begin{tabular}{|c|c|c|c|c|}
\hline Waterbody & Location & Species & $\mathrm{Hg} \mathrm{ppm}$ & PCB ppm \\
\hline ELK FORK LAKE & JACKSON COUNTY, WV & BLACK BULLHEAD & $<0.0175$ & $<0.02$ \\
\hline STONEWALL JACKSON LAKE & LEWIS COUNTY, WV & BLACK CRAPPIE & 0.133 & $<0.02$ \\
\hline BIG COAL RIVER & RACINE & BLCK REDHORSE SUCKER & 0.063 & $<0.02$ \\
\hline LITTLE KANAWHA RIVER & ELIZABETH & BLUEGILL & $<0.0175$ & $<0.02$ \\
\hline SHENANDOAH RIVER & ROUTE 9 BRIDGE & BLUEGILL & 0.163 & 1.197 \\
\hline SUMMIT LAKE & GREENBRIER COUNTY, WV & BLUEGILL & 0.045 & $<0.02$ \\
\hline SUMMIT LAKE & GREENBRIER COUNTY, WV & BLUEGILL & $<0.0175$ & $<0.02$ \\
\hline SUMMIT LAKE & GREENBRIER COUNTY, WV & BLUEGILL & 0.148 & $<0.02$ \\
\hline MIDDLE FORK & NEAR ELLAMORE & BROWN BULLHEAD & 0.113 & $<0.02$ \\
\hline SPRUCE KNOB LAKE & RANDOLPH COUNTY, WV & BROWN BULLHEAD & 0.150 & $<0.02$ \\
\hline CRANBERRY RIVER & IN CATCH \& RELEASE SEGMENT & BROWN TROUT & 0.073 & $<0.02$ \\
\hline CRANBERRY RIVER & IN CATCH \& RELEASE SEGMENT & BROWN TROUT & 0.373 & $<0.02$ \\
\hline WILLIAMS RIVER & BELOW TEA CREEK & BROWN TROUT & 0.100 & $<0.02$ \\
\hline TYGART VALLEY RIVER & ELKINS & BULLHEAD & $<0.0175$ & $<0.02$ \\
\hline BEAR ROCK LAKE & OHIO COUNTY, WV & CHANNEL CATFISH & $<0.0175$ & $<0.02$ \\
\hline BEAR ROCK LAKE & OHIO COUNTY, WV & CHANNEL CATFISH & $<0.0175$ & $<0.02$ \\
\hline BEECH FORK LAKE & WAYNE COUNTY, WV & CHANNEL CATFISH & 0.103 & 0.048 \\
\hline BEECH FORK LAKE & WAYNE COUNTY, WV & CHANNEL CATFISH & 0.213 & $<0.02$ \\
\hline \begin{tabular}{|l} 
BLUESTONE LAKE \\
\end{tabular} & SUMMERS COUNTY, WV & CHANNEL CATFISH & $<0.0175$ & 0.120 \\
\hline BLUESTONE LAKE & SUMMERS COUNTY, WV & CHANNEL CATFISH & $<0.0175$ & 0.249 \\
\hline CHEAT LAKE & MONONGALIA COUNTY, WV & CHANNEL CATFISH & 0.093 & 0.099 \\
\hline CHEAT LAKE & MONONGALIA COUNTY, WV & CHANNEL CATFISH & 0.025 & 0.137 \\
\hline ELK FORK LAKE & JACKSON COUNTY, WV & CHANNEL CATFISH & $<0.0175$ & 0.328 \\
\hline ELK FORK LAKE & JACKSON COUNTY, WV & CHANNEL CATFISH & $<0.0175$ & $<0.02$ \\
\hline GUYANDOTTE RIVER & AT GODBY HEIGHTS & CHANNEL CATFISH & 0.0425 & $<0.02$ \\
\hline GUYANDOTTE RIVER & AT GODBY HEIGHTS & CHANNEL CATFISH & 0.045 & 0.130 \\
\hline HUGHES RIVER & NEAR FREEPORT & CHANNEL CATFISH & 0.0975 & $<0.02$ \\
\hline HUGHES RIVER & NEAR FREEPORT & CHANNEL CATFISH & 0.1075 & 0.0649 \\
\hline HUGHES RIVER & NEAR FREEPORT & CHANNEL CATFISH & 0.1125 & 0.2488 \\
\hline KEE RESERVOIR & MERCER COUNTY, WV & CHANNEL CATFISH & 0.093 & $<0.02$ \\
\hline LITTLE COAL RIVER & NEAR MCCORKLE & CHANNEL CATFISH & 0.0800 & 0.0355 \\
\hline LITTLE KANAWHA RIVER & ELIZABETH & CHANNEL CATFISH & 0.193 & 0.083 \\
\hline LITTLE KANAWHA RIVER & ELIZABETH & CHANNEL CATFISH & 0.138 & 0.060 \\
\hline LITTLE KANAWHA RIVER & ELIZABETH & CHANNEL CATFISH & 0.225 & 0.270 \\
\hline MIDDLE ISLAND CREEK & MOUTH OF SUGAR CREEK & CHANNEL CATFISH & 0.200 & 0.219 \\
\hline MIDDLE ISLAND CREEK & MOUTH OF SUGAR CREEK & CHANNEL CATFISH & 0.148 & 0.163 \\
\hline MIDDLE ISLAND CREEK & MOUTH OF BUFFALO RUN & CHANNEL CATFISH & 0.188 & 0.113 \\
\hline MONONGAHELA RIVER & MORGANTOWN & CHANNEL CATFISH & 0.040 & 1.846 \\
\hline MONONGAHELA RIVER & MORGANTOWN & CHANNEL CATFISH & 0.040 & 0.662 \\
\hline MOUNT STORM LAKE & GRANT COUNTY, WV & CHANNEL CATFISH & $<0.0175$ & 0.116 \\
\hline MOUNT STORM LAKE & GRANT COUNTY, WV & CHANNEL CATFISH & $<0.0175$ & $<0.02$ \\
\hline MOUNT STORM LAKE & GRANT COUNTY, WV & CHANNEL CATFISH & $<0.0175$ & 0.367 \\
\hline R. D. BAILEY LAKE & MINGO/WYOMING COUNTIES, WV & CHANNEL CATFISH & $<0.0175$ & 0.119 \\
\hline R. D. BAILEY LAKE & MINGO/WYOMING COUNTIES, WV & CHANNEL CATFISH & 0.023 & 0.861 \\
\hline
\end{tabular}




\begin{tabular}{|c|c|c|c|c|}
\hline Waterbody & Location & Species & $\mathrm{Hg} \mathrm{ppm}$ & PCB ppm \\
\hline S BRANCH/POTOMAC RIVER & NEAR MOUTH & CHANNEL CATFISH & 0.053 & 0.058 \\
\hline S BRANCH/POTOMAC RIVER & NEAR MOUTH & CHANNEL CATFISH & 0.053 & 0.177 \\
\hline S BRANCH/POTOMAC RIVER & NEAR MOUTH & CHANNEL CATFISH & 0.055 & 0.208 \\
\hline S CAROLINA HATCHERY FISH & FISH STOCKED IN WV & CHANNEL CATFISH & $<0.0175$ & $<0.02$ \\
\hline S CAROLINA HATCHERY FISH & FISH STOCKED IN WV & CHANNEL CATFISH & $<0.0175$ & 0.08807 \\
\hline S CAROLINA HATCHERY FISH & FISH STOCKED IN WV & CHANNEL CATFISH & $<0.0175$ & 0.174 \\
\hline STONECOAL LAKE & LEWIS COUNTY, WV & CHANNEL CATFISH & 0.072 & $<0.02$ \\
\hline STONECOAL LAKE & LEWIS COUNTY, WV & CHANNEL CATFISH & 0.201 & 0.027 \\
\hline STONEWALL JACKSON LAKE & LEWIS COUNTY, WV & CHANNEL CATFISH & 0.0523 & $<0.02$ \\
\hline STONEWALL JACKSON LAKE & LEWIS COUNTY, WV & CHANNEL CATFISH & 0.281 & $<0.02$ \\
\hline SUMMERSVILLE LAKE & NICHOLAS COUNTY, WV & CHANNEL CATFISH & 0.1800 & 0.0800 \\
\hline TYGART LAKE & TAYLOR COUNTY, WV & CHANNEL CATFISH & 0.090 & 0.253 \\
\hline WEST FORK RIVER & NEAR SPELTER & CHANNEL CATFISH & 0.055 & 0.110 \\
\hline WEST FORK RIVER & NEAR SPELTER & CHANNEL CATFISH & 0.060 & 0.224 \\
\hline BUCKHANNON RIVER & HALL & FLATHEAD CATFISH & 0.075 & $<0.02$ \\
\hline EASTLYNN LAKE & WAYNE COUNTY, WV & FLATHEAD CATFISH & 0.100 & $<0.02$ \\
\hline LITTLE KANAWHA RIVER & ELIZABETH & FLATHEAD CATFISH & 0.225 & 0.048 \\
\hline NEW RIVER & SANDSTONE & FLATHEAD CATFISH & $<0.0175$ & $<0.02$ \\
\hline TUG FORK & KERMIT & FLATHEAD CATFISH & 0.030 & $<0.02$ \\
\hline HUGHES RIVER & NEAR FREEPORT & FRESHWATER DRUM & 0.223 & $<0.02$ \\
\hline DRY FORK & NEAR GLADWIN & SUCKER & 0.118 & $<0.02$ \\
\hline DRY FORK & NEAR GLADWIN & SUCKER & 0.125 & $<0.02$ \\
\hline EAST LYNN LAKE & WAYNE COUNTY, WV & SUCKER & 0.075 & $<0.02$ \\
\hline EAST LYNN LAKE & WAYNE COUNTY, WV & SUCKER & 0.108 & $<0.02$ \\
\hline LITTLE COAL RIVER & NEAR MCCORKLE & SUCKER & $<0.0175$ & $<0.02$ \\
\hline LITTLE COAL RIVER & NEAR MCCORKLE & SUCKER & 0.075 & $<0.02$ \\
\hline TUG FORK & KERMIT & SUCKER & 0.033 & $<0.02$ \\
\hline BEECH FORK LAKE & WAYNE COUNTY, WV & LARGEMOUTH BASS & 0.228 & $<0.02$ \\
\hline BEECH FORK LAKE & WAYNE COUNTY, WV & LARGEMOUTH BASS & 0.280 & $<0.02$ \\
\hline BEECH FORK LAKE & WAYNE COUNTY, WV & LARGEMOUTH BASS & 0.185 & $<0.02$ \\
\hline BURNSVILLE LAKE & BRAXTON COUNTY, WV & LARGEMOUTH BASS & 0.250 & 0.024 \\
\hline BURNSVILLE LAKE & BRAXTON COUNTY, WV & LARGEMOUTH BASS & 0.353 & $<0.02$ \\
\hline BURNSVILLE LAKE & BRAXTON COUNTY, WV & LARGEMOUTH BASS & 0.610 & $<0.02$ \\
\hline CASTLEMAN RUN LAKE & OHIO/BROOKE COUNTIES, WV & LARGEMOUTH BASS & 0.193 & $<0.02$ \\
\hline CASTLEMAN RUN LAKE & OHIO/BROOKE COUNTIES, WV & LARGEMOUTH BASS & 0.245 & $<0.02$ \\
\hline CHEAT LAKE & MONONGALIA COUNTY, WV & LARGEMOUTH BASS & 0.180 & $<0.02$ \\
\hline CHEAT LAKE & MONONGALIA COUNTY, WV & LARGEMOUTH BASS & 0.300 & $<0.02$ \\
\hline CHEAT LAKE & MONONGALIA COUNTY, WV & LARGEMOUTH BASS & 0.200 & 0.049 \\
\hline EAST LYNN LAKE & WAYNE COUNTY, WV & LARGEMOUTH BASS & 0.113 & 0.029 \\
\hline EAST LYNN LAKE & WAYNE COUNTY, WV & LARGEMOUTH BASS & 0.183 & $<0.02$ \\
\hline EAST LYNN LAKE & WAYNE COUNTY, WV & LARGEMOUTH BASS & 0.158 & $<0.02$ \\
\hline EAST LYNN LAKE & WAYNE COUNTY, WV & LARGEMOUTH BASS & 0.213 & $<0.02$ \\
\hline ELK FORK LAKE & JACKSON COUNTY, WV & LARGEMOUTH BASS & 0.388 & $<0.02$ \\
\hline
\end{tabular}




\begin{tabular}{|c|c|c|c|c|}
\hline Waterbody & Location & Species & $\mathrm{Hg} \mathrm{ppm}$ & PCB ppm \\
\hline ELK FORK LAKE & JACKSON COUNTY, WV & LARGEMOUTH BASS & 0.468 & $<0.02$ \\
\hline ELK FORK LAKE & JACKSON COUNTY, WV & LARGEMOUTH BASS & 0.900 & $<0.02$ \\
\hline KEE RESERVOIR & MERCER COUNTY, WV & LARGEMOUTH BASS & $<0.0175$ & 0.315 \\
\hline KEE RESERVOIR & MERCER COUNTY, WV & LARGEMOUTH BASS & 0.178 & $<0.02$ \\
\hline MOUNT STORM LAKE & GRANT COUNTY, WV & LARGEMOUTH BASS & 0.323 & $<0.02$ \\
\hline MOUNT STORM LAKE & GRANT COUNTY, WV & LARGEMOUTH BASS & $<0.0175$ & 0.023 \\
\hline MOUNT STORM LAKE & GRANT COUNTY, WV & LARGEMOUTH BASS & 0.110 & 0.103 \\
\hline PLUM ORCHARD LAKE & FAYETTE COUNTY, WV & LARGEMOUTH BASS & 0.238 & $<0.02$ \\
\hline PLUM ORCHARD LAKE & FAYETTE COUNTY, WV & LARGEMOUTH BASS & 0.205 & $<0.02$ \\
\hline SLEEPY CREEK LAKE & BERKELEY COUNTY, WV & LARGEMOUTH BASS & 0.250 & $<0.02$ \\
\hline SLEEPY CREEK LAKE & BERKELEY COUNTY, WV & LARGEMOUTH BASS & 0.325 & $<0.02$ \\
\hline SLEEPY CREEK LAKE & BERKELEY COUNTY, WV & LARGEMOUTH BASS & 0.350 & $<0.02$ \\
\hline STONECOAL LAKE & LEWIS COUNTY, WV & LARGEMOUTH BASS & 0.190 & $<0.02$ \\
\hline STONECOAL LAKE & LEWIS COUNTY, WV & LARGEMOUTH BASS & 0.453 & $<0.02$ \\
\hline STONEWALL JACKSON LAKE & LEWIS COUNTY, WV & LARGEMOUTH BASS & 0.260 & $<0.02$ \\
\hline STONEWALL JACKSON LAKE & LEWIS COUNTY, WV & LARGEMOUTH BASS & 0.888 & $<0.02$ \\
\hline STONEWALL JACKSON LAKE & LEWIS COUNTY, WV & LARGEMOUTH BASS & 0.370 & 0.078 \\
\hline SUMMERSVILLE LAKE & NICHOLAS COUNTY, WV & LARGEMOUTH BASS & 0.175 & $<0.02$ \\
\hline SUMMERSVILLE LAKE & NICHOLAS COUNTY, WV & LARGEMOUTH BASS & 0.460 & $<0.02$ \\
\hline SUMMIT LAKE & GREENBRIER COUNTY, WV & LARGEMOUTH BASS & 0.143 & $<0.02$ \\
\hline SUMMIT LAKE & GREENBRIER COUNTY, WV & LARGEMOUTH BASS & $<0.0175$ & $<0.02$ \\
\hline SUMMIT LAKE & GREENBRIER COUNTY, WV & LARGEMOUTH BASS & 0.210 & $<0.02$ \\
\hline SUTTON LAKE & BRAXTON COUNTY, WV & LARGEMOUTH BASS & 0.275 & $<0.02$ \\
\hline SUTTON LAKE & BRAXTON COUNTY, WV & LARGEMOUTH BASS & 0.509 & $<0.02$ \\
\hline SUTTON LAKE & BRAXTON COUNTY, WV & LARGEMOUTH BASS & 0.648 & $<0.02$ \\
\hline TYGART LAKE & TAYLOR COUNTY, WV & LARGEMOUTH BASS & 0.178 & $<0.02$ \\
\hline TYGART VALLEY RIVER & ELKINS & LARGEMOUTH BASS & 0.178 & $<0.02$ \\
\hline TYGART VALLEY RIVER & ELKINS & LARGEMOUTH BASS & 0.330 & $<0.02$ \\
\hline TUG FORK & KERMIT & LONGNOSE GAR & 0.090 & 0.083 \\
\hline BUCKHANNON RIVER & HALL & NORTHERN HOGSUCKER & 0.108 & $<0.02$ \\
\hline CHERRY RIVER & FENWICK & NORTHERN HOGSUCKER & 0.1775 & $<0.02$ \\
\hline CHERRY RIVER & FENWICK & NORTHERN HOGSUCKER & 0.0775 & $<0.02$ \\
\hline DRY FORK/TUG FORK & NEAR CANEBRAKE & NORTHERN HOGSUCKER & 0.020 & $<0.02$ \\
\hline DRY FORK/TUG FORK & NEAR CANEBRAKE & NORTHERN HOGSUCKER & 0.025 & $<0.02$ \\
\hline GREENBRIER RIVER & 3 Ml. ABOVE SEEBERT & NORTHERN HOGSUCKER & 0.1825 & $<0.02$ \\
\hline GREENBRIER RIVER & WILLOWWOOD & NORTHERN HOGSUCKER & 0.175 & $<0.02$ \\
\hline GREENBRIER RIVER & WILLOWWOOD & NORTHERN HOGSUCKER & 0.185 & 0.054 \\
\hline NEW RIVER & SANDSTONE & NORTHERN HOGSUCKER & $<0.0175$ & $<0.02$ \\
\hline NEW RIVER & SANDSTONE & NORTHERN HOGSUCKER & 0.020 & $<0.02$ \\
\hline SHAVERS FORK & 8.7 MLLES ABOVE MOUTH & NORTHERN HOGSUCKER & 0.335 & $<0.02$ \\
\hline SHAVERS FORK & 8.7 MLLES ABOVE MOUTH & NORTHERN HOGSUCKER & 0.1375 & $<0.02$ \\
\hline WILLIAMS RIVER & BELOW TEA CREEK & NORTHERN HOGSUCKER & 0.09 & $<0.02$ \\
\hline JENNINGS RANDOLPH LAKE & MINERAL COUNTY, WV & RAINBOW TROUT & $<0.0175$ & $<0.02$ \\
\hline
\end{tabular}




\begin{tabular}{|c|c|c|c|c|}
\hline Waterbody & Location & Species & $\mathrm{Hg} \mathrm{ppm}$ & PCB ppm \\
\hline JENNINGS RANDOLPH LAKE & MINERAL COUNTY, WV & RAINBOW TROUT & $<0.0175$ & $<0.02$ \\
\hline N FORK/S BRANCH & 6 MILES ABOVE MOUTH & RAINBOW TROUT & $<0.0175$ & $<0.02$ \\
\hline SLATY FORK & TOWN OF SLATY FORK & RAINBOW TROUT & 0.043 & $<0.02$ \\
\hline SPRUCE KNOB LAKE & RANDOLPH COUNTY, WV & RAINBOW TROUT & $<0.0175$ & $<0.02$ \\
\hline SPRUCE KNOB LAKE & RANDOLPH COUNTY, WV & RAINBOW TROUT & $<0.0175$ & $<0.02$ \\
\hline WILLIAMS RIVER & BELOW TEA CREEK & RAINBOW TROUT & 0.063 & $<0.02$ \\
\hline OPEQUON CREEK & BRIDGE & REDBREAST SUNFISH & 0.085 & $<0.02$ \\
\hline S BRANCH/POTOMAC RIVER & OLD FIELDS & REDBREAST SUNFISH & 0.033 & $<0.02$ \\
\hline SHENANDOAH RIVER & ROUTE 9 BRIDGE & REDBREAST SUNFISH & 0.095 & 0.134 \\
\hline BURNSVILLE LAKE & BRAXTON COUNTY, WV & REDHORSE SUCKER & 0.179 & $<0.02$ \\
\hline BURNSVILLE LAKE & BRAXTON COUNTY, WV & REDHORSE SUCKER & 0.250 & 0.038 \\
\hline CHEAT LAKE & MONONGALIA COUNTY, WV & REDHORSE SUCKER & 0.048 & $<0.02$ \\
\hline CHEAT LAKE & MONONGALIA COUNTY, WV & REDHORSE SUCKER & 0.075 & 0.087 \\
\hline ELK RIVER & GASSAWAY & REDHORSE SUCKER & 0.058 & 0.062 \\
\hline ELK RIVER & GASSAWAY & REDHORSE SUCKER & 0.243 & $<0.02$ \\
\hline MONONGAHELA RIVER & MORGANTOWN & REDHORSE SUCKER & 0.035 & 0.042 \\
\hline \begin{tabular}{|l|} 
N FORK/S BRANCH \\
\end{tabular} & 6 MLLES ABOVE MOUTH & REDHORSE SUCKER & 0.245 & $<0.02$ \\
\hline S BRANCH/POTOMAC RIVER & OLD FIELDS & REDHORSE SUCKER & 0.145 & $<0.02$ \\
\hline S BRANCH/POTOMAC RIVER & OLD FIELDS & REDHORSE SUCKER & 0.070 & $<0.02$ \\
\hline S BRANCH/POTOMAC RIVER & NEAR MOUTH & REDHORSE SUCKER & 0.115 & $<0.02$ \\
\hline S BRANCH/POTOMAC RIVER & OLD FIELDS & REDHORSE SUCKER & 0.075 & $<0.02$ \\
\hline S BRANCH/POTOMAC RIVER & NEAR MOUTH & REDHORSE SUCKER & 0.170 & 0.173 \\
\hline S FORK/S BRANCH & NEAR MOUTH OF BRAKE RUN & REDHORSE SUCKER & 0.173 & $<0.02$ \\
\hline SHAVERS FORK & 8.7 MILES ABOVE MOUTH & REDHORSE SUCKER & 0.373 & 0.315 \\
\hline SHENANDOAH RIVER & ROUTE 9 BRIDGE & REDHORSE SUCKER & 0.385 & 2.109 \\
\hline SUMMERSVILLE LAKE & NICHOLAS COUNTY, WV & REDHORSE SUCKER & 0.178 & $<0.02$ \\
\hline SUTTON LAKE & BRAXTON COUNTY, WV & REDHORSE SUCKER & 0.063 & $<0.02$ \\
\hline WHEELING CREEK & NEAR SHERRARD & REDHORSE SUCKER & 0.113 & $<0.02$ \\
\hline WHEELING CREEK & NEAR SHERRARD & REDHORSE SUCKER & 0.263 & 0.092 \\
\hline WHEELING CREEK & NEAR SHERRARD & REDHORSE SUCKER & 0.278 & $<0.02$ \\
\hline BLUESTONE RIVER & NEAR EADS MILL & ROCK BASS & 0.038 & $<0.02$ \\
\hline BLUESTONE RIVER & NEAR EADS MILL & ROCK BASS & 0.045 & $<0.02$ \\
\hline DRY FORK/TUG FORK & NEAR CANEBRAKE & ROCK BASS & 0.068 & $<0.02$ \\
\hline MEADOW RIVER & RUSSELVILLE & ROCK BASS & 0.060 & $<0.02$ \\
\hline MEADOW RIVER & RUSSELVILLE & ROCK BASS & 0.245 & $<0.02$ \\
\hline \begin{tabular}{|l|} 
N FORK/S BRANCH \\
\end{tabular} & 6 MILES ABOVE MOUTH & ROCK BASS & 0.135 & $<0.02$ \\
\hline \begin{tabular}{|l} 
N FORK/S BRANCH \\
\end{tabular} & 6 MILES ABOVE MOUTH & ROCK BASS & 0.388 & $<0.02$ \\
\hline NEW RIVER & SANDSTONE & ROCK BASS & 0.020 & $<0.02$ \\
\hline \begin{tabular}{|l|} 
NEW RIVER \\
\end{tabular} & SANDSTONE & ROCK BASS & 0.103 & $<0.02$ \\
\hline S BRANCH/POTOMAC RIVER & OLD FIELDS & ROCK BASS & 0.105 & $<0.02$ \\
\hline GUYANDOTTE RIVER & AT GODBY HEIGHTS & SAUGER & 0.140 & $<0.02$ \\
\hline HUGHES RIVER & NEAR FREEPORT & SAUGER & 0.298 & $<0.02$ \\
\hline HUGHES RIVER & NEAR FREEPORT & SAUGER & 0.530 & $<0.02$ \\
\hline LITTLE COAL RIVER & NEAR MCCORKLE & SAUGER & 0.100 & 0.060 \\
\hline MONONGAHELA RIVER & DAM & SAUGER & 0.182 & 0.081 \\
\hline
\end{tabular}




\begin{tabular}{|c|c|c|c|c|}
\hline Waterbody & Location & Species & $\mathrm{Hg} \mathrm{ppm}$ & PCB ppm \\
\hline MONONGAHELA RIVER & DAM & SAUGER & 0.099 & 0.197 \\
\hline MONONGAHELA RIVER & DAM & SAUGER & 0.270 & $<0.02$ \\
\hline STONEWALL JACKSON LAKE & LEWIS COUNTY, WV & SAUGEYE & 0.330 & $<0.02$ \\
\hline BIG COAL RIVER & RACINE & SUCKER & 0.028 & 0.078 \\
\hline BIG COAL RIVER & RACINE & SMALLMOUTH BASS & 0.033 & $<0.02$ \\
\hline BIG COAL RIVER & RACINE & SMALLMOUTH BASS & $<0.0175$ & $<0.02$ \\
\hline \begin{tabular}{|l} 
BLUESTONE RIVER \\
\end{tabular} & NEAR EADS MILL & SMALLMOUTH BASS & 0.075 & $<0.02$ \\
\hline BUCKHANNON RIVER & HALL & SMALLMOUTH BASS & 0.118 & $<0.02$ \\
\hline BUCKHANNON RIVER & IN BUCKHANNON & SMALLMOUTH BASS & 0.250 & $<0.02$ \\
\hline CHEAT LAKE & MONONGALIA COUNTY, WV & SMALLMOUTH BASS & 0.340 & $<0.02$ \\
\hline \begin{tabular}{|l} 
CHERRY RIVER \\
\end{tabular} & FENWICK & SMALLMOUTH BASS & 0.155 & $<0.02$ \\
\hline \begin{tabular}{|l|} 
DRY FORK \\
\end{tabular} & NEAR GLADWIN & SMALLMOUTH BASS & 0.310 & $<0.02$ \\
\hline \begin{tabular}{|l} 
DRY FORK \\
\end{tabular} & NEAR GLADWIN & SMALLMOUTH BASS & 0.613 & $<0.02$ \\
\hline ELK RIVER & GASSAWAY & SMALLMOUTH BASS & 0.378 & $<0.02$ \\
\hline \begin{tabular}{|l|} 
ELK RIVER \\
\end{tabular} & GASSAWAY & SMALLMOUTH BASS & 0.258 & $<0.02$ \\
\hline GREENBRIER RIVER & WILLOWWOOD & SMALLMOUTH BASS & 0.273 & $<0.02$ \\
\hline GREENBRIER RIVER & 3 Ml. ABOVE SEEBERT & SMALLMOUTH BASS & 0.425 & $<0.02$ \\
\hline GREENBRIER RIVER & WILLOWWOOD & SMALLMOUTH BASS & 0.220 & $<0.02$ \\
\hline GREENBRIER RIVER & 3 Ml. ABOVE SEEBERT & SMALLMOUTH BASS & 0.483 & $<0.02$ \\
\hline GUYANDOTTE RIVER & AT GODBY HEIGHTS & SMALLMOUTH BASS & 0.093 & $<0.02$ \\
\hline \begin{tabular}{|l} 
JENNINGS RANDOLPH LAKE \\
\end{tabular} & MINERAL COUNTY, WV & SMALLMOUTH BASS & 0.158 & $<0.02$ \\
\hline JENNINGS RANDOLPH LAKE & MINERAL COUNTY, WV & SMALLMOUTH BASS & 0.115 & $<0.02$ \\
\hline JENNINGS RANDOLPH LAKE & MINERAL COUNTY, WV & SMALLMOUTH BASS & 0.138 & $<0.02$ \\
\hline MEADOW RIVER & RUSSELVILLE & SMALLMOUTH BASS & 0.118 & $<0.02$ \\
\hline MEADOW RIVER & RUSSELVILLE & SMALLMOUTH BASS & 0.108 & $<0.02$ \\
\hline MIDDLE FORK & NEAR ELLAMORE & SMALLMOUTH BASS & 0.198 & $<0.02$ \\
\hline MIDDLE FORK & NEAR ELLAMORE & SMALLMOUTH BASS & 0.215 & $<0.02$ \\
\hline MONONGAHELA RIVER & DAM & SMALLMOUTH BASS & 0.077 & $<0.02$ \\
\hline MONONGAHELA RIVER & DAM & SMALLMOUTH BASS & 0.108 & $<0.02$ \\
\hline MONONGAHELA RIVER & DAM & SMALLMOUTH BASS & 0.116 & 0.126 \\
\hline N FORK/S BRANCH & 6 MILES ABOVE MOUTH & SMALLMOUTH BASS & 0.468 & $<0.02$ \\
\hline N FORK/S BRANCH & 6 MILES ABOVE MOUTH & SMALLMOUTH BASS & 0.458 & $<0.02$ \\
\hline NEW RIVER & SANDSTONE & SMALLMOUTH BASS & 0.035 & $<0.02$ \\
\hline NEW RIVER & SANDSTONE & SMALLMOUTH BASS & 0.068 & $<0.02$ \\
\hline NEW RIVER & THURMOND & SMALLMOUTH BASS & 0.093 & $<0.02$ \\
\hline NEW RIVER & SANDSTONE & SMALLMOUTH BASS & 0.098 & $<0.02$ \\
\hline S BRANCH/POTOMAC RIVER & OLD FIELDS & SMALLMOUTH BASS & 0.148 & $<0.02$ \\
\hline S BRANCH/POTOMAC RIVER & NEAR MOUTH & SMALLMOUTH BASS & 0.258 & $<0.02$ \\
\hline S BRANCH/POTOMAC RIVER & OLD FIELDS & SMALLMOUTH BASS & 0.198 & $<0.02$ \\
\hline S BRANCH/POTOMAC RIVER & NEAR MOUTH & SMALLMOUTH BASS & 0.325 & $<0.02$ \\
\hline S BRANCH/POTOMAC RIVER & OLD FIELDS & SMALLMOUTH BASS & 0.235 & $<0.02$ \\
\hline S FORK/S BRANCH & NEAR MOUTH OF BRAKE RUN & SMALLMOUTH BASS & 0.640 & $<0.02$ \\
\hline SHAVERS FORK & 8.7 MILES ABOVE MOUTH & SMALLMOUTH BASS & 0.305 & $<0.02$ \\
\hline SHAVERS FORK & 8.7 MILES ABOVE MOUTH & SMALLMOUTH BASS & 0.525 & $<0.02$ \\
\hline
\end{tabular}




\begin{tabular}{|c|c|c|c|c|}
\hline Waterbody & Location & Species & $\mathrm{Hg} \mathrm{ppm}$ & PCB ppm \\
\hline SHENANDOAH RIVER & ROUTE 9 BRIDGE & SMALLMOUTH BASS & 0.748 & 0.066 \\
\hline SUMMERSVILLE LAKE & NICHOLAS COUNTY, WV & SMALLMOUTH BASS & 0.023 & $<0.02$ \\
\hline SUMMERSVILLE LAKE & NICHOLAS COUNTY, WV & SMALLMOUTH BASS & 0.228 & $<0.02$ \\
\hline \begin{tabular}{|l|} 
TYGART LAKE \\
\end{tabular} & TAYLOR COUNTY, WV & SMALLMOUTHBASS & 0.243 & 0.083 \\
\hline TYGART LAKE & TAYLOR COUNTY, WV & SMALLMOUTHBASS & 0.235 & $<0.02$ \\
\hline TYGART LAKE & TAYLOR COUNTY, WV & SMALLMOUTH BASS & 0.320 & 0.034 \\
\hline WHEELING CREEK & & SMALLMOUTH BASS & 0.438 & $<0.02$ \\
\hline WHEELING CREEK & NEAR BURCHES RUN & SMALLMOUTH BASS & 0.350 & $<0.02$ \\
\hline WHEELING CREEK & NEAR BURCHES RUN & SMALLMOUTHBASS & 0.475 & $<0.02$ \\
\hline BEECH FORK LAKE & WAYNE COUNTY, WV & SPOTTED BASS & 0.173 & $<0.02$ \\
\hline BEECH FORK LAKE & WAYNE COUNTY, WV & SPOTTED BASS & 0.533 & $<0.02$ \\
\hline BIG COAL RIVER & RACINE & SPOTTED BASS & 0.023 & $<0.02$ \\
\hline BIG COAL RIVER & RACINE & SPOTTED BASS & 0.093 & $<0.02$ \\
\hline BLUESTONE LAKE & SUMMERS COUNTY, WV & SPOTTED BASS & $<0.0175$ & $<0.02$ \\
\hline BLUESTONE LAKE & SUMMERS COUNTY, WV & SPOTTED BASS & $<0.0175$ & $<0.02$ \\
\hline BLUESTONE LAKE & SUMMERS COUNTY, WV & SPOTTED BASS & $<0.0175$ & $<0.02$ \\
\hline BURNSVILLE LAKE & BRAXTON COUNTY, WV & SPOTTED BASS & 0.360 & 0.088 \\
\hline BURNSVILLE LAKE & BRAXTON COUNTY, WV & SPOTTED BASS & 0.399 & $<0.02$ \\
\hline EAST LYNN LAKE & WAYNE COUNTY, WV & SPOTTED BASS & 0.160 & $<0.02$ \\
\hline EAST LYNN LAKE & WAYNE COUNTY, WV & SPOTTED BASS & 0.245 & $<0.02$ \\
\hline GUYANDOTTE RIVER & AT GODBY HEIGHTS & SPOTTED BASS & 0.023 & $<0.02$ \\
\hline GUYANDOTTE RIVER & AT GODBY HEIGHTS & SPOTTED BASS & 0.148 & $<0.02$ \\
\hline LITTLE COAL RIVER & NEAR MCCORKLE & SPOTTED BASS & 0.043 & $<0.02$ \\
\hline \begin{tabular}{|l} 
LITTLE COAL RIVER \\
\end{tabular} & NEAR MCCORKLE & SPOTTED BASS & 0.070 & $<0.02$ \\
\hline LITTLE KANAWHA RIVER & ELIZABETH & SPOTTED BASS & 0.368 & $<0.02$ \\
\hline LITTLE KANAWHA RIVER & ELIZABETH & SPOTTED BASS & 0.395 & $<0.02$ \\
\hline MIDDLE ISLAND CREEK & NEAR WEST UNION & SPOTTED BASS & 0.508 & 0.050 \\
\hline MIDDLE ISLAND CREEK & NEAR WEST UNION & SPOTTED BASS & 0.513 & $<0.02$ \\
\hline MIDDLE ISLAND CREEK & NEAR WEST UNION & SPOTTED BASS & 0.500 & $<0.02$ \\
\hline R. D. BAILEY LAKE & MINGO/WYOMING COUNTIES, WV & SPOTTED BASS & 0.038 & $<0.02$ \\
\hline R. D. BAILEY LAKE & MINGO/WYOMING COUNTIES, WV & SPOTTED BASS & 0.220 & 0.170 \\
\hline SUTTON LAKE & BRAXTON COUNTY, WV & SPOTTED BASS & 0.374 & $<0.02$ \\
\hline SUTTON LAKE & BRAXTON COUNTY, WV & SPOTTED BASS & 0.292 & $<0.02$ \\
\hline MIDDLE FORK & NEAR ELLAMORE & SUNFISH & 0.095 & $<0.02$ \\
\hline NEW RIVER & SANDSTONE & SUNFISH & $<0.0175$ & $<0.02$ \\
\hline S FORK/S BRANCH & NEAR MOUTH OF BRAKE RUN & SUNFISH & 0.260 & $<0.02$ \\
\hline S FORK/S BRANCH & NEAR MOUTH OF BRAKE RUN & SUNFISH & 0.163 & $<0.02$ \\
\hline STONEWALL JACKSON LAKE & LEWIS COUNTY, WV & WALLEYE & 0.163 & $<0.02$ \\
\hline SUMMERSVILLE LAKE & NICHOLAS COUNTY, WV & WALLEYE & 0.569 & $<0.02$ \\
\hline SUMMERSVILLE LAKE & NICHOLAS COUNTY, WV & WALLEYE & 0.515 & 0.201 \\
\hline TYGART LAKE & TAYLOR COUNTY, WV & WALLEYE & 0.280 & $<0.02$ \\
\hline TYGART LAKE & TAYLOR COUNTY, WV & WALLEYE & 0.398 & $<0.02$ \\
\hline TYGART LAKE & TAYLOR COUNTY, WV & WALLEYE & 0.570 & $<0.02$ \\
\hline
\end{tabular}




\begin{tabular}{|l|l|l|c|c|}
\hline \multicolumn{1}{|c|}{ Waterbody } & \multicolumn{1}{c|}{ Location } & \multicolumn{1}{c|}{ Species } & Hg ppm & PCBs ppm \\
\hline TYGART LAKE & TAYLOR COUNTY, WV & WALLEYE & 0.483 & 0.048 \\
\hline CHEAT LAKE & MONONGALIA COUNTY, WV & WHITE BASS & 0.193 & 0.249 \\
\hline CHEAT LAKE & MONONGALIA COUNTY, WV & WHITE BASS & 0.573 & $<0.02$ \\
\hline CHEAT LAKE & MONONGALIA COUNTY, WV & WHITE BASS & 0.303 & 0.470 \\
\hline HUGHES RIVER & NEAR FREEPORT & WHITE BASS & 0.438 & $<0.02$ \\
\hline MONONGAHELA RIVER & MORGANTOWN LOCKS \& DAM & WHITE BASS & 0.075 & $<0.02$ \\
\hline TYGART LAKE & TAYLOR COUNTY, WV & WHITE BASS & 0.275 & 0.129 \\
\hline TYGART LAKE & TAYLOR COUNTY, WV & WHITE BASS & 0.765 & 0.098 \\
\hline STONECOAL LAKE & LEWIS COUNTY, WV & WHITE CRAPPIE & 0.226 & $<0.02$ \\
\hline CRANBERRY RIVER & IN CATCH AND RELEASE SEGMENT & WHITE SUCKER & 0.053 & $<0.02$ \\
\hline MIDDLE FORK & NEAR ELLAMORE & WHITE SUCKER & 0.148 & $<0.02$ \\
\hline N FORK/S BRANCH & 6 MILES ABOVE MOUTH & WHITE SUCKER & 0.298 & $<0.02$ \\
\hline OPEQUON CREEK & MARTINGSBURG AT RT. 45 BRIDGE & WHITE SUCKER & 0.280 & 0.051 \\
\hline SLATY FORK & TOWN OF SLATYY FORK & WHITE SUCKER & 0.063 & $<0.02$ \\
\hline SLEEPY CREEK LAKE & BERKELEY COUNTY, WV & YELLOW BULLHEAD & 0.225 & $<0.02$ \\
\hline TYGART LAKE & TAYLOR COUNTY, WV & YELLOW PERCH & $<0.0175$ & $<0.02$ \\
\hline TYGART LAKE & TAYLOR COUNTY, WV & YELLOW PERCH & $<0.0175$ & $<0.02$ \\
\hline
\end{tabular}

John

$\mathrm{H}$. 